\title{
Saccharomyces cerevisiae na redução de aflatoxicoses e o efeito na distribuição e na excreção da radioatividade de $\mathrm{AFB}_{1}{ }^{3} \mathrm{H}$ em ratos
}

\section{ANTONIO SAMPAIO BAPTISTA}

Tese apresentada ao Centro de Energia Nuclear na Agricultura, Universidade de São Paulo, para obtenção do título de Doutor em Ciências, Área de Concentração: Energia Nuclear na Agricultura.

$$
\text { PIRACICABA }
$$

Estado de São Paulo - Brasil

Março - 2005 
Saccharomyces cerevisiae na redução de aflatoxicoses e 0 efeito na distribuição e na excreção da radioatividade de $\mathrm{AFB}_{1}{ }^{3} \mathrm{H}$ em ratos

\title{
ANTONIO SAMPAIO BAPTISTA
}

Engenheiro Agrônomo

Orientador: Prof. Dr. ADIBE LUIZ ABDALLA

\author{
Tese apresentada ao Centro de Energia \\ Nuclear na Agricultura", Universidade de São \\ Paulo, para obtenção do título de Doutor em \\ Ciências, Área de Concentração: Energia \\ Nuclear na Agricultura. \\ PIRACICABA \\ Estado de São Paulo - Brasil \\ Março - 2005
}




\title{
Dados Internacionais de Catalogação na Publicação (CIP)
}

\section{Seção Técnica da Biblioteca - CENA/USP}

\author{
Baptista, Antonio Sampaio \\ Saccharomyces cer evisiae na redução de aflatoxicoses e o efeito na distribuição e na \\ excreção da radioatividade de $\mathrm{AFB}_{1}{ }^{3} \mathrm{H}$ em ratos/ Antonio Sampaio Baptista. - - \\ Piracicaba, 2005.
}

94p. : il.

Tese (Doutorado) - - Centro de Energia Nuclear na A gricultura , 2005. Bibliografia.

1.Aflatoxina 2. Controle biológico 3. Ensaio biológico 4. Leveduras 5. Metabolismo 6. Radioisótopos I. Título

CDD 663.14:636.087.2

"Permitida a cópia total ou parcial deste documento, desde que citada a fonte - $\mathrm{O}$ autor" 


\section{AOS MEUS PAIS}

\section{Jorge Alcântara Baptista e Tereza Sampaio Baptista Por tudo que fizeram por mim.}

\section{AOS MEUS IRMÃOS}

Aparecido Sampaio Baptista

Ângela Maria Sampaio Baptista e Ana Angelita Sampaio Baptista

Pelo carinho e pelo apoio

\section{OFEREÇO}

À minha querida avó

Maria Angélica (in memoriam)

DEDICO 
"Deus não escolhe os capacitados, Deus capacita os escolhidos"

(Autor desconhecido) 


\section{AGRADECIMENTOS}

Poucas tarefas são tão agradáveis como o reconhecimento de minha gratidão a todos que colaboraram neste esforço de maneiras tão diferentes. Entre estes quero agradecer:

A Deus, pela vida, pela fé, pela perseverança e por tantas vitórias;

Ao Centro de Energia Nuclear na Agricultura, da Universidade de São Paulo, por me proporcionar a oportunidade de utilizar a infra-estrutura básica para a realização deste Curso;

À CPG do CENA, em especial às secretárias Alzira, Claúdia, Neuda e Regina e ao Prof. Dr. Francisco José Krug (Coordenador) por todo o apoio e a cooperação no decorrer do Curso;

À FAPESP pelo auxílio financeiro indispensável à realização desta pesquisa;

Ao Prof. Dr. Adibe Luiz Abdalla pela oportunidade de realizar este estudo, orientação, convivência, amizade e confiança demonstrada;

Ao Prof. Dr. Jorge Horii pela sua influência na minha formação profissional e pela sua perspicácia, críticas e sugestões tão úteis neste trabalho e acima de tudo pela forma amiga e sincera com que me incentivou neste esforço;

Ao Prof. Dr. Júlio Marcos Melges Walder pela amizade e pela orientação no início do Curso e em outros momentos tão importantes para a realização deste trabalho;

Ao Prof. Dr. Mário Roberto Vizioli (FOP/UNICAMP) pela sua participação essencial nas análises histopatológicas;

Ao Prof. Dr. Vírgilio F. do N. Filho pelo auxílio e pelas boas dicas para a execução dos radioensaios;

Ao Prof. Dr. Waldemar Tornisiello por permitir utilizar a estrutura do Laboratório de Ecotoxicologia-CENA/USP e, aos técnicos Dorelli, Luciana e Rosângela, pelo auxílio no preparo de amostras para as análises de radioatividade; 
À Profạ. Dra Sônia de Stefano Piedade pela orientação na realização das análises estatísticas;

À Profạ. Dra. Siu Mui Tsai pela sua colaboração no envio da documentação do meu projeto de bolsa à Fapesp;

À Camila Maistro Patreze pela revisão e pelas sugestões tão valiosas para a redação e estruturação deste trabalho;

Aos Mestres que, direta ou indiretamente, participaram na minha formação;

Ao Lécio e a Regina, técnicos do LANA/CENA/USP, e à Profa Dorinha M.S.S.V. Kennedy (LANA/CENA/USP) pelo apoio e pela colaboração indispensáveis na execução desta pesquisa;

Aos estagiários do LANA, em especial, Andréia C. Zampronio e Deise S. Pires, as quais prestaram enorme contribuição na execução dos experimentos e com as quais aprendi muito.

Aos meus amigos e colegas do LANA/CENA/USP pela amizade, apoio e convivência.

Aos companheiros Eduardo Micotti da Glória e Maria Antonia Calori-Domingues pela amizade e sugestões tão valiosas;

À Ivani Zambello e Claudinéia Soares pela amizade e, pelo auxílio na produção e nas análises de micotoxinas;

Ao Departamento de Agroindústria, Alimentos e Nutrição (LAN/ESALQ/USP), em especial aos responsáveis pelos Setores de Açúcar e Álcool, Óleos e Gorduras e Micotoxinas, onde desenvolvi parte deste trabalho;

À Marilia Ribeiro Garcia Henyei, Diretora da Biblioteca do CENA/USP, pelo auxílio na revisão das citações bibliográficas;

Aos funcionários do Restaurante Universitário pelo atendimento e dedicação;

Aos colegas de Curso pela amizade e convivência do dia a dia;

Em especial, aos amigos Alailson Santiago, André Alcarde, André Belluco, André Sesso, César de Castro, Camila, Cláudio Aguiar, Dani, Denise Viola, Evandro Zanini, Gustavo Lyra, Ives, Jailson, João Célio, Jonas Ruschel, Luciana Kolm, Lúcio, Luís Timm, Mara Pessoa, Matheus, Régis Heirichs, Severino, Thais Nobre e outros tão importantes quanto, os quais não me recordo no momento, com os quais tive o prazer de viver bons momentos e aprender muito.

A todos que me incentivaram e que direta ou indiretamente contribuíram para a execução deste trabalho. 


\section{SUMÁRIO}

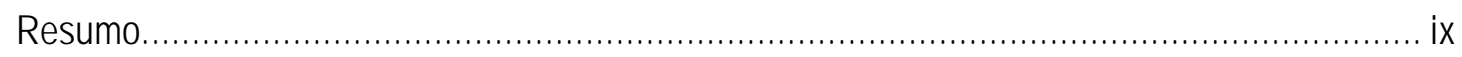

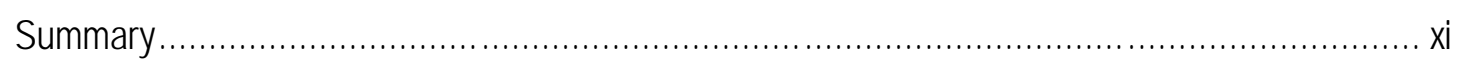

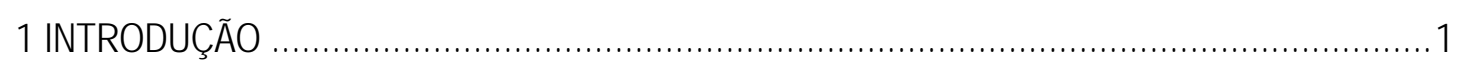

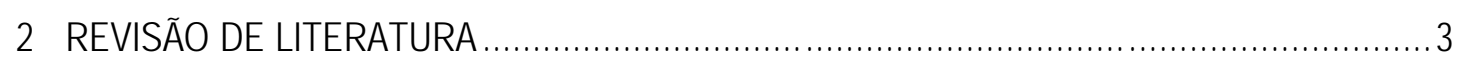

2.1 Aflatoxinas, ocorrência e importância econômica...............................................................

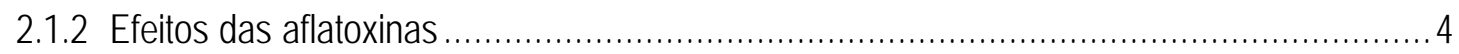

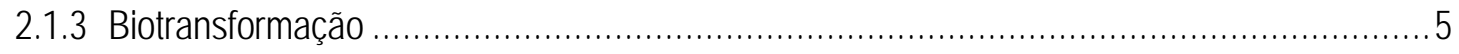

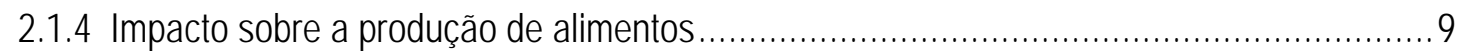

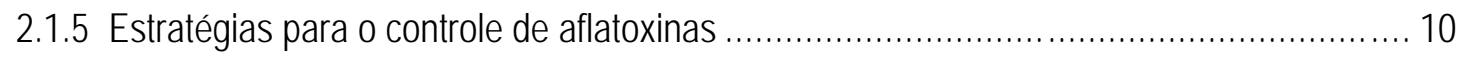

2.1.6 Radiotraçadores no estudo do metabolismo de aflatoxinas ....................................... 12

3 Comparação entre duas linhagens de Saccharomyces cerevisiae no controle de

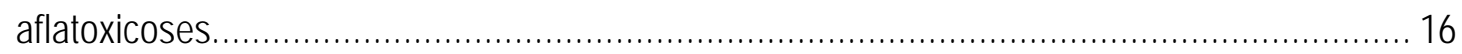

Resumo

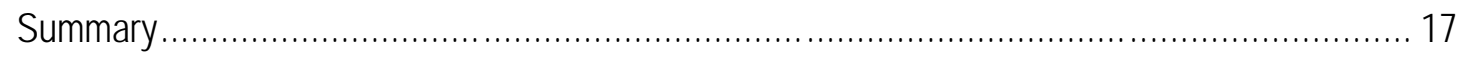

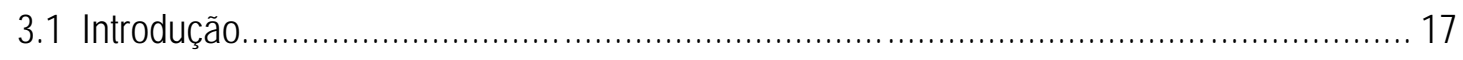

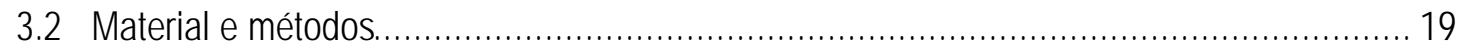

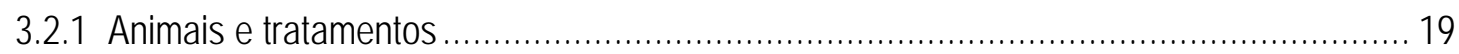

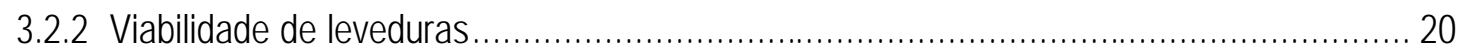

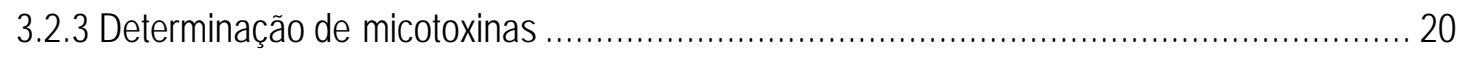

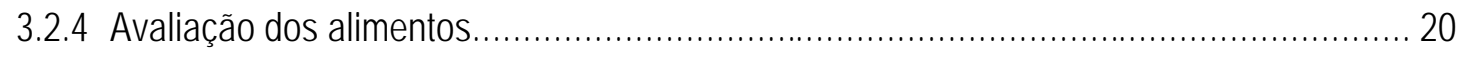

3.2.5. Biometria de órgãos internos e provas bioquímicas ................................................ 20 


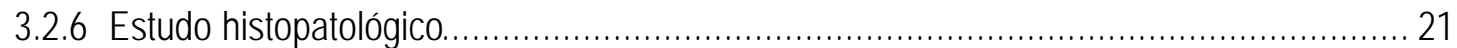

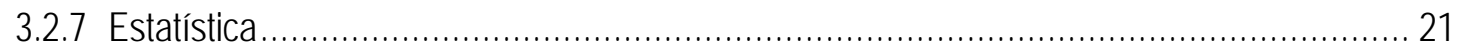

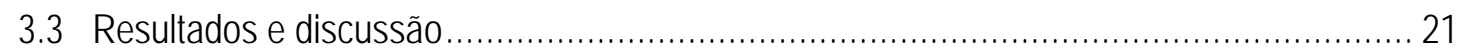

3.3.1 Avaliação alimentar e peso relativo de órgãos internos.......................................... 21

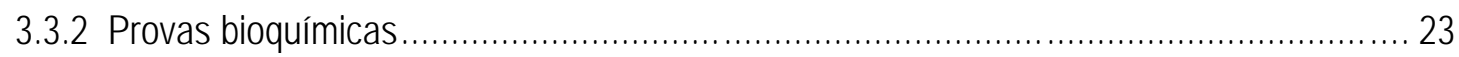

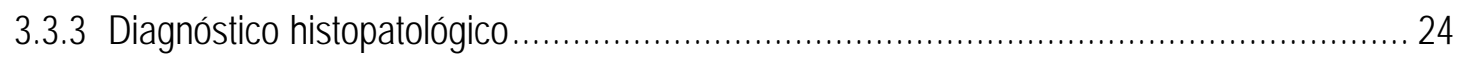

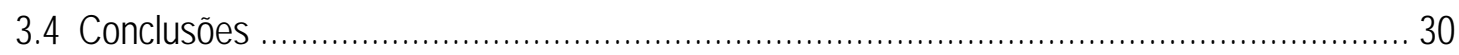

4 Diferentes doses de Saccharomyces cerevisiae da linhagem Y1026 no controle de

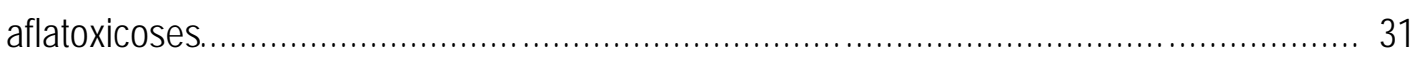

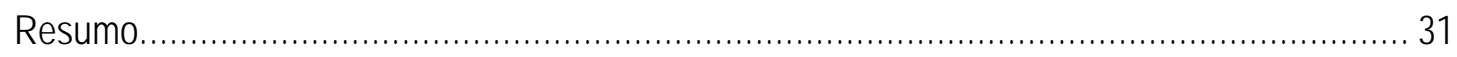

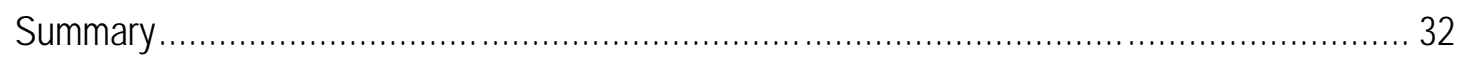

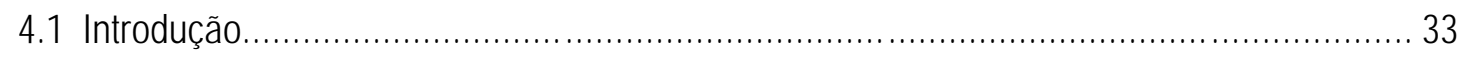

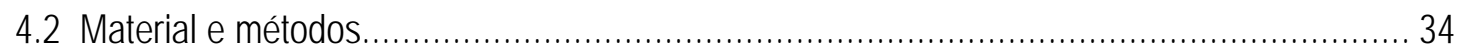

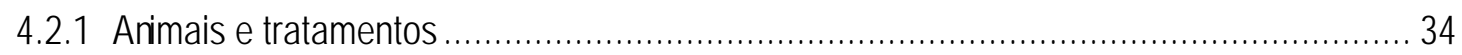

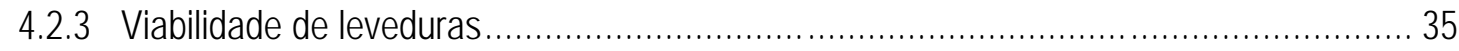

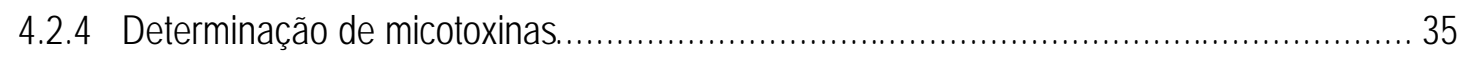

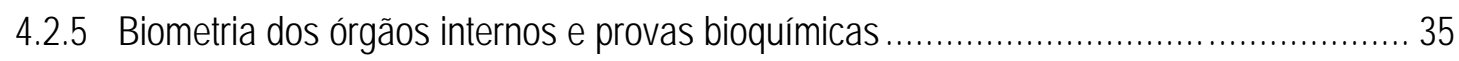

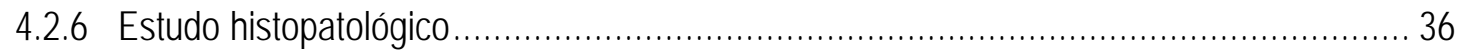

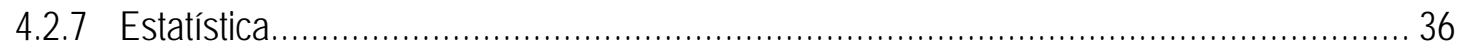

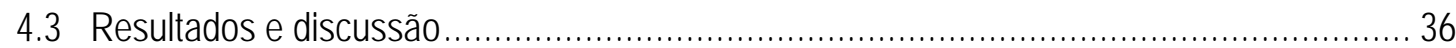

4.3.1 Parâmetros para avaliação do aproveitamento do alimento......................................... 36

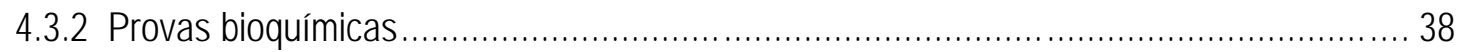

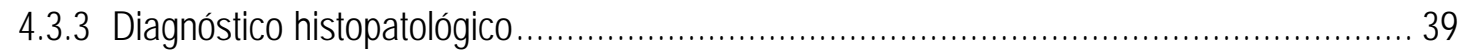

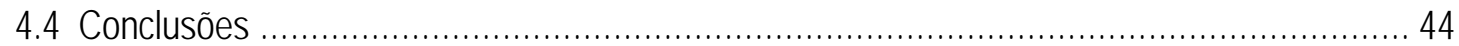

5 Absorção, distribuição e excreção de aflatoxina radiomarcada $\left(\mathrm{AFB}_{1}{ }^{3} \mathrm{H}\right)$ em ratos ................. 45

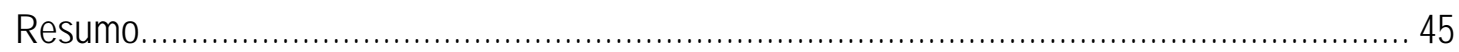

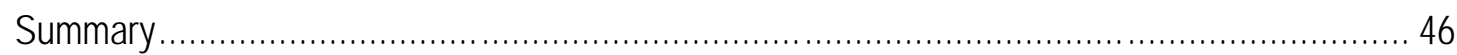

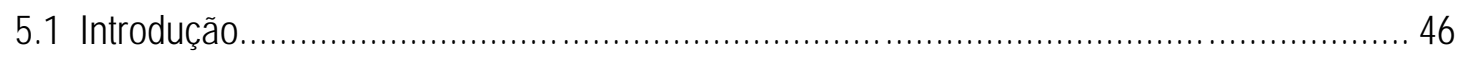

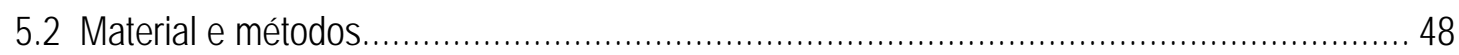

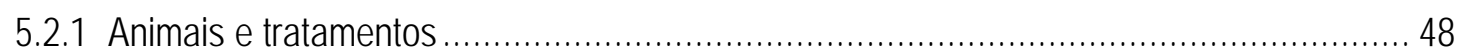




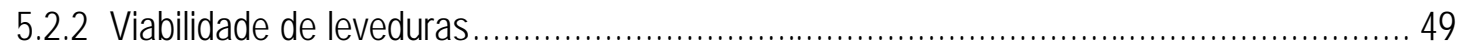

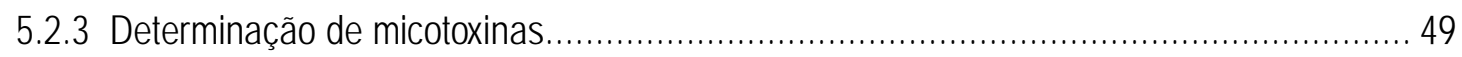

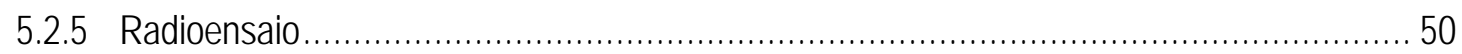

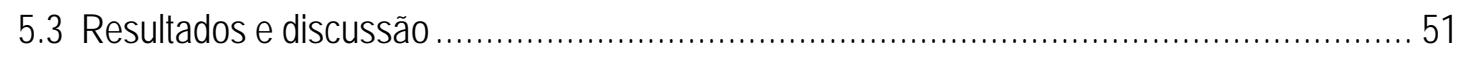

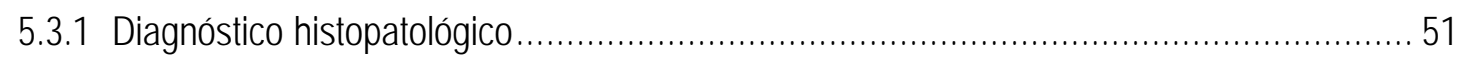

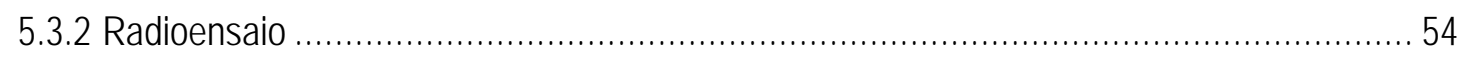

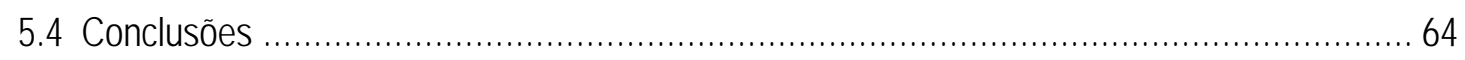

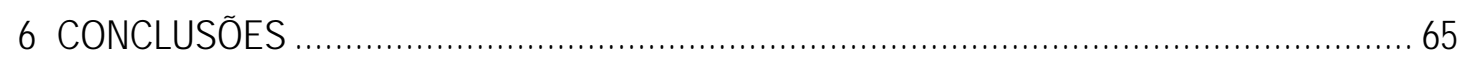

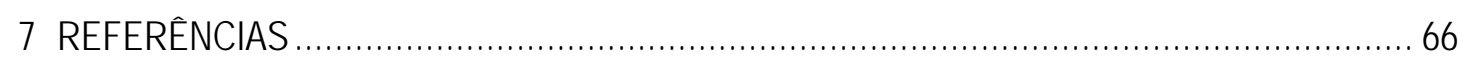




\section{Saccharomyces cerevisiae na redução de aflatoxicoses e o efeito na distribuição e na excreção da radioatividade de $\mathrm{AFB}_{1}{ }^{3} \mathrm{H}$ em ratos}

Autor: Antonio Sampaio Baptista

Orientador: Prof. Dr. Adibe Luiz Abdalla

\section{Resumo}

Para avaliar o efeito de diferentes linhagens de leveduras, Saccharomyces cerevisiae, vivas, na redução de aflatoxicoses e, contribuir para o entendimento do modo de ação destas leveduras sobre aflatoxina $\mathrm{B}_{1}$ marcada com trítio $\left(\mathrm{AFB}_{1}{ }^{3} \mathrm{H}\right)$, foram conduzidos três experimentos. No primeiro experimento, foram utilizados ratos Wistar para investigar o efeito de duas linhagens de S. cerevisiae (Y1026 e Y904), e da suplementação com aminoácidos na redução de aflatoxicoses. O bioensaio, em delineamento inteiramente casualizado, foi conduzido por 28 dias para avaliar sete tratamentos (dietas), sendo um livre de aflatoxinas e seis contendo $400 ? \mathrm{~g} \mathrm{~kg}^{-1}$ de aflatoxinas; destes, cinco com leveduras, a saber: Y1026 (níveis de 0,5; 1,0 e 5,0\%) e Y904 (níveis de 1\% e 1\%+1000ppm de metionina + 1000 ppm de cisteína). Não foram observadas diferenças estatistiticamente significativas no consumo de alimentos, ganho de peso, conversão alimentar e função hepática entre os animais submetidos aos diferentes tratamentos. No entanto, o exame histopatológico revelou que os animais que receberam aflatoxinas sem leveduras sofreram danos mais severos em relação aos que receberam aflatoxinas juntamente com leveduras, os quais apresentaram poucos danos celulares. Conclui-se que, as duas linhagens de leveduras em todas as situações estudadas apresentaram capacidade de reduzir as aflatoxicoses. O segundo ensaio foi conduzido com o objetivo de investigar o efeito de diferentes doses da levedura Y1026 no controle de aflatoxicoses em ratos. Neste bioensaio, os animais foram distribuídos em gaiolas individuais ao acaso, e foram submetidos a 7 tratamentos (dietas) 
por 60 dias, sendo uma sem aflatoxinas e seis contaminadas com $550 ? \mathrm{~g} \mathrm{~kg}^{-1}$ de aflatoxinas, das quais cinco contendo a levedura Y1026 (doses: 0,2; 0,5; 1,0; 2,0 e 5,0\%). Foram realizadas análises sobre 0 aproveitamento do alimento, funções hepáticas e tecido hepático. O consumo de alimentos pelos animais alimentados com dieta livre de aflatoxinas foi maior do que pelos animais que receberam dietas contaminadas com a toxina, os demais parâmetros para julgamento do aproveitamento dos alimentos não diferiram estatisticamente entre os animais que foram submetidos a ambos os tratamentos. A atividade de enzimas hepáticas foi maior nos animais que não receberam a toxina do que nos demais. O exame histopatológico revelou que os animais que receberam aflatoxinas e aflatoxinas mais 0,2 ou $0,5 \%$ da levedura apresentaram sinais claros de hepatotoxidez e que os demais animais que ingeriram os níveis mais altos da levedura sofreram poucos danos celulares. Conclui-se que, a dose de levedura Y1026 aplicada foi determinante na redução das aflatoxicoses em ratos Wistar. No último bioensaio, trintaratos foram alimentados por 28 dias seguindo-se quatro tratamentos (dietas): uma dieta livre de aflatoxinas e as outras três contaminadas com 500 ? g kg-1 de aflatoxina, sendo uma o controle com aflatoxinas e as outras duas na presença de $1 \%$ de levedura Y1026 ou Y904. No $18^{\circ}$ dia, seis animais de cada um dos tratamentos que recebiam aflatoxinas foram transferidos para gaiolas metabólicas, onde permaneceram por cinco dias em adaptação e, no $23^{\circ}$ dia, estes receberam, por via oral, uma dose simples de 2? Ci/animal de $\mathrm{AFB}_{1}{ }^{3} \mathrm{H}$. Os animais restantes (três ratos em cada um dos tratamentos) foram utilizados nos exames histopatológicos. A radioatividade foi determinada 12, 24, 48, 72, 96 e 120 horas após a introdução do material radioativo nos animais. Os animais que receberam dietas contendo as leveduras apresentaram a absorção, a distribuição e a excreção da radioatividade mais lenta do que aqueles que não receberam os probióticos. O exame histopatológico revelou que os animais que ingeriram leveduras sofreram poucos danos celulares e que aqueles que não receberam levedura foram muito afetados. As leveduras apresentaram habilidade de reduzir aflatoxicoses e modificaram a absorção, a distribuição ea excreção da radioatividade de $\mathrm{AFB}_{1}{ }^{3} \mathrm{H}$ em ratos Wistar. 
The capacity of Saccharomyces cerevisiae to reduce aflatoxicosis and its effect on the distribution and excretion of $\mathrm{AFB}_{1}{ }^{3} \mathrm{H}$ in rats

Author: Antonio Sampaio Baptista

Adviser: Prof. Dr. Adibe Luiz Abdalla

\section{Summary}

The capacity of Saccharomyces cerevisiae, from two Strain, to reduce aflatoxicosis and the effect of yeast cells on tritium-labeled $\mathrm{B}_{1}$ aflatoxin $\left(\mathrm{AFB}_{1}{ }^{3} \mathrm{H}\right)$ were investigated in three distinct studies. The effects of S. cerevisiae Y1026 and Y904 strains and diets amended with amino acids on the reduction of aflatoxicosis in Wistar rats were evaluated in the first study. A completely randomized block-designed bioassay with Wistar rats was conducted to evaluate seven formulations (Treatments), which consisted of an aflatoxin-free formulation and six formulations with $400 ? \mathrm{~g} \mathrm{~kg}$ 1 of aflatoxins. Of these, three formulations had the yeast strain $Y 1026$ (at 0.5, 1.0 and 5.0\%) and two had the strain Y904 (at 1\% and 1\%+1000ppm of methionine +1000 ppm of cysteine). No statistical differences were observed for the food consumption, weights of the body organs, feed conversion and liver function between the animals fed the different treatments. Histopathological analysis revealed that animals fed aflatoxins diet without yeast cells had liver damage caused by the toxins and those that were fed aflatoxin-diet amended with yeast cells had less liver tissue damage. Therefore, the results obtained suggested that the presence of either yeast strain in the formulations caused a reduction in aflatoxicosis. The second study was conducted to investigate the effect of different dosages of the yeast strain Y1026 on the control of aflatoxicosis in rats. The bioassay was conducted with rats randomly placed in individual cages and fed seven different diets (7 treatments) for 60 days. These were an aflatoxin-free formulation and six others containing aflatoxins at 550 ? g kg-1, of which five had the yeast strain Y1026 (concentrations at $0.2 ; 0.5 ; 1.0 ; 2.0$ and 5\%). Feed conversion, liver functions indexes and liver tissue parameters were evaluated. The activity of the liver enzymes was greater in animals that fed the toxin-free diet when compared to other animals. Histopathological analysis showed that animals fed 
aflatoxin containing diets with and without 0.2 or $0.5 \%$ yeast cells showed clear signs of hepatotoxicity, while animals that were fed diets with higher concentrations of yeast cells had less liver tissue damage. The concentration of the yeast cells (Y1026) used in the formulations was correlated with the reduction of aflatoxicosis in Wistar rats. The third study fed Wistar rats an aflatoxin-free diet and diets with aflatoxins (at 500 ? g kg-1) and aflatoxin amended with a $1 \%$ concentration of the yeast strains Y1026 or Y904. In this study, six animals from each group fed the aflatoxin-diets were transferred to metabolic cages and received a single oral dose of $\mathrm{AFB}_{1}{ }^{3 \mathrm{H}}$ at 2? Ci/animal. Three animals of each treatment were kept at the initial conditions and their liver tissues were used for histopathological analysis. Radiation levels in the animals were monitored at $12,24,48,72,96$ and $120 \mathrm{~h}$ after receiving the labeled aflatoxin. Animals fed diets with active yeast cells had absorption, distribution and excretion levels of the labeled toxin different than those that did not receive the probiotic. Histopathological analysis showed that animals fed diets with yeast cells had less liver tissue damage while those fed the aflatoxin-diet had significantly higher liver damage. Therefore, these results indicate that active yeast cells have the ability to reduce aflatoxicosis and modify the absorption, distribution and excretion of radioactivity from $\mathrm{AFB}_{1}{ }^{3} \mathrm{H}$ in Wistar rats. 


\section{INTRODUÇÃO}

A cada dia aumenta a preocupação das pessoas com a qualidade de vida. A produção e 0 aproveitamento ce alimentos saudáveis êm participação importante para 0 bem estar de pessoas e de animais. Por outro lado, a presença de substância nocivas em alimentos, mesmo que em pequenas concentrações, quando consumidas por períodos prolongados pode promover efeito inverso aos dos famosos alimentos funcionais e proporcionar sérios prejuízos à saúde. Entre estas substâncias, merecem atenção as aflatoxinas, as quais podem estar presentes em vasta gama de produtos alimentícios e conduzir a danos indesejáveis.

As aflatoxinas são substâncias químicas altamente tóxicas, produzidas principalmente por fungos das espécies Aspergillus flavus e A. parasiticus, que sob condições favoráveis de temperatura e de umidade se desenvolvem sobre os alimentos e podem produzir as toxinas. A facilidade e freqüência com que isso acontece torna a sua presença comum em muitos alimentos (Heathcote, 1984).

Os efeitos das aflatoxinas podem ser bioquímicos e biológicos. Bioquimicamente, as aflatoxinas podem afetar os metabolismos de energia, de carboidratos e de lipídios e também dos ácidos nucléicos e das proteínas. Os efeitos biológicos são carcinogenicidade, mutagenicidade, teratogenicidade, hepatotoxicidade e aflatoxicoses (Ellis et al., 1991; Bradburn \& Coker, 1993)

No mundo todo, há uma crescente conscientização das sérias conseqüências que a ingestão de concentrações elevadas de aflatoxinas podem causar à saúde humana e dos animais (FAO, 1993). A exposição a níveis crônicos de aflatoxinas, provavelmente, conduza ao câncer. Assim, a ingestão de alimentos contaminados com doses altas ou baixas representa sérios riscos à saúde pública (Roebuch \& Maxuilenko, 1994).

Os alimentos contaminados com aflatoxinas atingem diretamente os animais, principalmente através de grãos contaminados e os humanos geralmente são afetados pela 
presença da toxina em grãos e frutas ou a partir de produtos de origem animal (leite, ovos, carne e outros) (Galvano et al., 2001).

O impacto econômico resultante da presença de aflatoxinas ocorre em todos os níveis da cadeia produtora de alimentos, desde a produção vegetal e animal, com a diminuição da produtividade, até o processamento, o armazenamento e a distribuição, com o aumento do custo de obtenção do produto final. Além disso, ainda há custos com saúde, fiscalização e com importação. Por essas razões a prevenção, a descontaminação e a desintoxicação são de grande importância (Fonseca, 1984; Charmley et al., 1995; Galvano et al., 2001).

Esta pesquisa foi conduzida com os propósitos de estudar a aplicação de leveduras para reduzir os danos promovidos pela ingestão de aflatoxinas e de contribuir para o esclarescimento do modo de ação da levedura Saccharomyces cerevisiae sobre afltoxinas.

Desta forma, neste trabalho serão relatadas, em capítulos distintos, três pesquisas desenvolvidas. O primeiro capítulo trata do estudo conduzido para avaliar o efeito de duas linhagens de Saccharomyces cerevisiae no controle de aflatoxicoses. A justificativa para que essa pesquisa tenha sido conduzida é que se diferentes linhagens de keveduras apresentam efeitos semelhantes para o controle de aflatoxicoses, a recomendação técnica do uso deste microrganismo para tal finalidade não deve ser limitada a uma única linhagem. No segundo capítulo, é apresentada uma investigação feita com o propósito de verificar o efeito de diferentes doses da levedura Y1026 no controle de aflatoxicoses. Essa pesquisa foi realizada pelo fato de que o conhecimento da melhor dose da levedura a ser recomendada para dcançar um efeito desejado na redução de aflatoxicoses é importante para a tomada de decisões, considerando a viabilidade técnica-econômica. O terceiro capítulo aborda um estudo executado para verificar 0 efeito das linhagens de leveduras Y1026 e Y904 sobre aflatoxicoses e o efeito destas linhagens sobre a absorção, a distribuição e a eliminação da radioatividade de $A F B{ }_{1}^{3} \mathrm{H}$ em ratos Wistar. Essa última investigação é relevante porque permite ter informação sobre o modo de ação das leveduras sobre aflatoxinas e com isso adotar diretrizes que possibilitem obter leveduras mais eficazes para o controle de aflatoxicoses. 


\section{REVISÃO DE LITERATURA}

\subsection{Aflatoxinas, ocorrência e importância econômica}

Segundo Heathcote (1984), as aflatoxinas são metabólitos secundários, tóxicos, produzidos por algumas linhagens de Aspergillus flavus e $A$. parasiticus, além de outras espécies como A. nomius (Frisvad \& Thrane, 1996). Sob condições favoráveis de temperatura e umidade, estes fungos podem crescer em certos alimentos, resultando na produção de aflatoxinas (Fortnum, 1986; Lillehoj, 1986).

As principais aflatoxinas produzidas pelos fungos são $B_{1}, B_{2}, G_{1}, e G_{2}$. Com relação aos efeitos tóxicos das principais aflatoxinas sabe-se que apresentam o seguinte grau de toxicidade: $B_{1}>G_{1}>B_{2}>G_{2}$. Destas, a $B_{1}$ é mais cancerígena (Carnaghan et al., 1963).

No mundo todo, há uma crescente conscientização das sérias conseqüências que a ingestão de concentrações elevadas de aflatoxinas pode causar à saúde humana e dos animais (FAO, 1993) e mesmo as concentrações baixas, desde que continuamente.

A exposição às concentrações crônicas é mais provável do que às concentrações agudas e existem evidências que levam a crer que o consumo de concentrações crônicas de aflatoxinas, provavelmente, conduzam ao câncer. Assim, as exposições a concentrações crônicas destas toxinas representam sérios problemas para a saúde pública (Roebuch \& Maxuilenko, 1994).

As aflatoxinas podem afetar os metabolismos de energia, de carboidratos e de lipídios e também dos ácidos nucléicos e das proteínas. Podem promover ainda carcinogenicidade, mutagenicidade, teratogenicidade, hepatotoxicidade e aflatoxicoses (Ellis et al., 1991; Bradburn \& Coker, 1993).

O impacto econômico resultante da contaminação por aflatoxina ocorre em todas as etapas da produção vegetal e animal, comercialização e utilização dos produtos (Kubena et al., 1990). A facilidade e freqüência com que as aflatoxinas contaminam os produtos agrícolas, e ao 
mesmo tempo, a exposição de animais a níveis crônicos destes compostos químicos, via dieta contaminada, podem ser as principais diferenças entre o lucro e o prejuízo para a atividade agroindustrial (Jones et al., 1982; Nichols, 1983; Hamilton, 1984).

Em muitos países, os níveis permitidos de aflatoxinas em produtos alimentícios estão entre 5 a 50 ?g kg-1 (FAO, 1993). No Brasil, a presença de aflatoxinas nos alimentos é regulada pela Resolução № 34.176 do Ministério da Saúde (Brasil, 1977), que estabelece 30 ?g kg-1 para o somatório das aflatoxinas $B_{1}$ e $G_{1}$, e mais recentemente, internalizando as normas do Mercosul, pela Portaria № 183 do dia 21 de março de 1996, do Ministério da Agricultura do Abastecimento e da Reforma Agrária, que estabelece o limite máximo de 20 ?g kg-1, para 0 somatório das aflatoxinas $B_{1}, B_{2}, G_{1}$, e $G_{2}$ (Brasil, 1996).

Segundo Salay \& Mercadante (2002), empresas brasileiras que possuem controle de qualidade e monitoram a ocorrência de aflatoxinas e outras micotoxinas, apresentam um custo médio de US\$ 55,90 por amostra analisada.

\subsubsection{Efeitos das aflatoxinas}

As aflatoxinas causam alteração no metabolismo de carboidratos e prejudicam 0 transporte de lipídios, resultando em diminuição nas concentrações de glicose e acúmulo de lipídios dentro dos hepatócitos (Wogan, 1973; Rodricks \& Stoloff, 1977; Heathcote \& Hibbert, 1978; Naber \& Wallace, 1979).

As aflatoxinas podem se ligar com o DNA afetando a sua atividade, em alguns casos, a aflatoxina na forma epóxido, se liga ao DNA impedindo a transcrição (Clifford \& Rees, 1967). Pode-se ligar ainda ao RNA impedindo a síntese de proteínas, além de unir-se ao RNAm impedindo que a RNApolimerase faça reparos e com isso ocorrer a formação de células anormais (Smith \& Moss, 1985). 


\subsubsection{Biotransformação}

As aflatoxinas são rapidamente absorvidas pelo sistema gastrintestinal e através da corrente sangüínea atingem o fígado, onde são rapidamente biotransformadas. No tecido hepático, a AFB 1 é degradada em duas fases, (I) pela sua biotransformação para um produto intermediário mais tóxico e (II) pela desintoxicação do metabólito intermediário para outro produto facilmente degradado (Ellis et al., 1991).

Na primeira fase, $a \mathrm{AFB}_{1}$ é metabolizada para a sua forma reativa através de reações que envolvem ativação, hidrólise, redução e oxidação. Nestas reações há liberação ou introdução de grupos funcionais $\left(-\mathrm{OH},-\mathrm{SH},-\mathrm{NH}_{2}, \mathrm{Ou}-\mathrm{COOH}\right.$ ) para tornar a molécula mais hidrofílica. Nesta fase, há um aumento na atividade enzimática e o metabolismo da aflatoxina é mais rápido (Parkinson, 1996; Hayes et al., 1991).

Na segunda fase (desintoxicação) os produtos intermediários são transformados em metabólitos menos tóxicos e então excretados do organismo. Isto ocorre através da formação de alguns conjugados com substâncias endógenas, tais como ácido glicurônico, aminoácidos, sulfatos e glutationa. A biotransformação na fase II é mais lenta do que na fase I. Os produtos intermediários, tais como a forma epóxido da $\mathrm{AFB}_{1}$, reagem com macromoléculas das células do fígado, resultando em fígados pálidos e gordurosos, com necroses de moderada a intensa e hemorragias do parênquima hepático (Swenson et al., 1974; Hsieh, 1987; Hayes et al., 1991; Parkinson, 1996)

Patterson (1973) propôs uma rota da biotransformação de AFB 1 em células susceptíveis, segundo este modelo o transporte da AFBı é através da membrana plasmática, onde ela é ativada pela função mista de monoxigenases microssomais e a forma mais reativa formada é a AFB1-8,9 epóxido. A AFB 1 pode também ser convertida para outras formas reversíveis tais como aflatoxicol, $A F M_{1}, \mathrm{AFP}_{1}, \mathrm{AFQ}_{1}, \mathrm{AFB}_{2}$, as quais podem ser eliminadas pelos hepatócitos (Patterson, 1973; Hsieh, 1987; Wong \& Hsieh, 1980; Swenson et al., 1974) (Figura 1). 


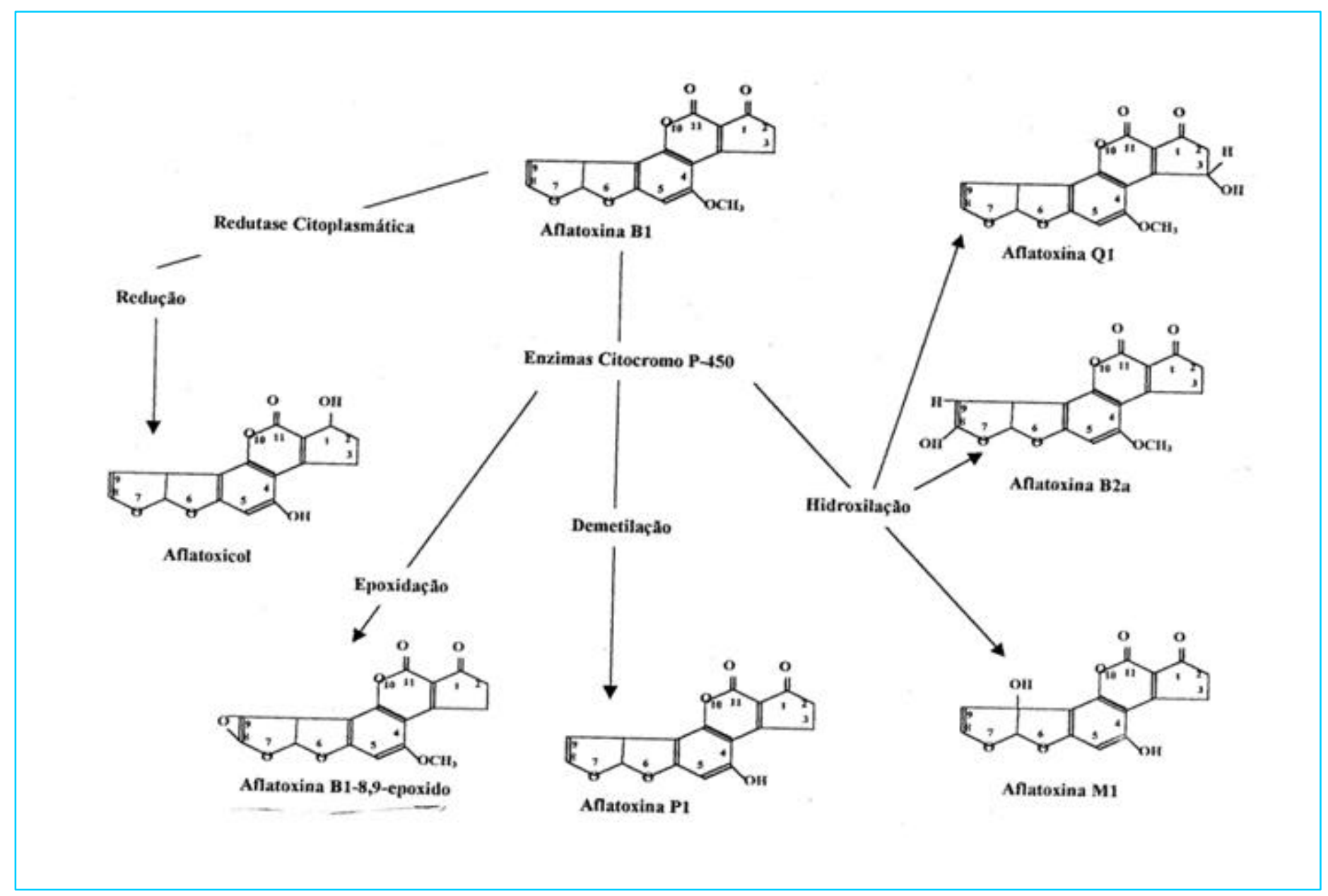

Figura 1 - Biotransformação da aflatoxina $B_{1}($ Pozzi, 2000) 
A principal reação de desintoxicação da AFB1 epóxido reativa envolve a conjugação com glutationa, mediada pelo complexo enzimático glutationa-S-transferase (Degen \& Neuman, 1978). A AFB1 conjugada à glutationa é excretada primariamente através da bile (Hsieh, 1987). O conjugado, entretanto, pode ser hidrolisado pela microflora intestinal e liberar a $\mathrm{AFB}_{1}$ para reabsorção e circulação enterohepática (Hsieh \& Wong, 1982). A AFB1-8,9-epóxido pode também ser desintoxicada pelo UDP-glicoronil transferase, sulfotransferase e possivelmente pelo sistema de hidrólise epóxido (Hayes et al., 1991). As outras aflatoxinas (AFB $1, A_{1} \mathrm{~F}_{1}, \mathrm{AFM}_{1}$ ) podem se juntar a grupos sulfatos e conjugadas podem ser excretadas pela urina (Wong \& Hsieh, 1980).

A resistência ou susceptibilidade relativa de diferentes espécies animais à genotoxicidade e citotoxicidade de $\mathrm{AFB}_{1}$ é dependente da formação metabólica de $A \mathrm{FB}_{1}$-8,9-epóxido e da capacidade da espécie animal em convertê-la em produtos conjugados para que possam ser excretados. Pelo fato da desintoxicação envolver a formação de conjugado com glutationa, animais que apresentam alta atividade desta enzima parecem ser mais resistentes aos danos induzidos pelas aflatoxinas (ex: camundongo). Isto também pode ser visto em ratas fêmeas, as quais são mais resistentes às afaltoxinas do que ratos machos por estas enzimas serem mais ativas (Hsieh et al., 1977; Roebuck \& Wogan, 1977; Hayes et al., 1991).

Em indivíduos expostos à altas doses ou por períodos prolongados às aflatoxinas podem induzir efeitos biológicos, tais como: carcinogenicidade, mutagenicidade, teratogenecidade e hepatotocixidade (Mclean \& Dutton, 1995).

Os efeitos biológicos da aflatoxinas são influenciados pela espécie, sexo, estado nutricional do animal e outros agentes químicos e biológicos. Além disso, o nível de dose e 0 período de exposição à toxina são importantes (Smith \& Moss, 1985)

Os danos das aflatoxinas em animais, em geral, são expressos como aflatoxicoses, as quais podem levar ou não o indivíduo a morte, dependendo se é uma exposição aguda ou crônica. Os sintomas de aflatoxicoses agudas, geralmente, incluem: fígados descoloridos, pálidos, congestionados; hemorragias no fígado, rins e tratogastrintestinal; diminuição no teor de proteínas no soro sangüíneo e aumento da atividade de algumas enzimas hepáticas; nos casos de exposição a níveis crônicos pode ser obsevado fígados congestionados, com zonas 
necróticas e hemorragias, proliferação de ductos biliares, rins congestionados e enterites hemorrágicas (Smith \& Moss, 1985; Ellis et al., 1991).

As aflatoxinas são metabolizadas no fígado e, portanto, os sintomas primários de suas micotoxicoses se expressam como alterações histológicas neste órgão. Em ratos e patos os sintomas iniciais são caracterizados por necroses hepáticas, as quais são oriundas de degeneração hidrópica e alterações gordurosas nos hepatócitos (Theron, 1965; Clifford \& Rees, 1967).

As aflatoxinas podem causar danos ao fígado na maioria dos animais domésticos e experimentais (Stark, 1986) e têm sido relacionadas com muitas doenças em humanos, incluindo hepatocarcinoma. Embora o fígado seja o alvo primário, em muitos casos, lesões cancerígenas foram observadas nos rins, cólon, pulmão e glândulas lacrimais de vários animais alimentados com rações contaminadas por aflatoxinas (Stoloff, 1977).

Segundo Barnes \& Butler (1964), os ratos parecem ser, em parte, tolerantes à aflatoxina, uma vez que são capazes de sobreviver por um curto período experimental alimentando-se com uma dieta contendo altas concentrações de farelo tóxico. Entretanto, em investigação por período prolongado com ingestão, de cerca, de $20 \%$ da dieta contaminada com a toxina, foram observadas reduções na taxa de crescimento dos animais e do consumo do alimento. Uma alimentação prolongada, de várias semanas, promove lesões no fígado e hepatomas (Lancaster et al., 1961).

As aflatoxinas prejudicam as células e o sistema humoral, tornando o indivíduo mais susceptível às infecções por bactérias, vírus, fungos e doenças parasitárias (Rodricks \& Stoloff, 1977; Cysewski et al., 1978; Miller et al., 1978; Bouton et al., 1980; Thurston et al., 1980; Harvey et al., 1988).

Baixas concentrações de aflatoxinas na dieta pode reduzir a resistência de frangos à Pasteurella, Salmonella, Coccidia e Candida e, em suínos, aumentar a severidade de desinterias por infecções causadas por Erysipelotrix rhusiopathiae e Salmonelloses (Píer \& Heddleston, 1970; Richard et al., 1975; Cysewski et al., 1978; Miller et al., 1978, Joens et al., 1981).

Em animais, os sintomas clínicos mais comuns incluem: anorexia, diminuição do ganho de peso, menor aproveitamento do alimento utilizado, hemorragias e susceptibilidade ao meio ambiente e estresse por microrganismos (Edds \& Bortel, 1983). 


\subsubsection{Impacto sobre a produção de alimentos}

Encontram-se contaminações por aflatoxinas em todos os níveis do sistema de produção de alimentos, incluindo a produção animal e a vegetal, o processamento e a distribuição (Charmley et al., 1995; Garcia et al., 1997). Frangos de corte alimentados com ração contendo $3,5 \mathrm{mg} \mathrm{kg}^{-1}$ de aflatoxinas apresentaram perdas de peso corporal e aumento nos pesos de fígado e rins (Smith et al., 1992).

Stanley et al. (1993), observaram que frangos de corte que receberam dietas contaminadas com $5 \mathrm{mg} \mathrm{kg}^{-1}$ de aflatoxinas apresentavam $15 \%$ de perda de peso em relação ao grupo controle que não foi exposto à toxina.

A dose de 385 ?g kg-1 aflatoxinas em ração foi o limite de tolerância encontrado para suínos (Southern \& Clawson, 1979). Animais desta espécie que receberam $2 \mathrm{mg} \mathrm{kg}^{-1}$ aflatoxinas em ração apresentaram redução de $26 \%$ do peso corporal em relação ao grupo controle (Huff et al., 1986). Também foi observado por Hussein \& Brasel (2001) redução de ganho de peso de 7 $\mathrm{kg}$, no grupo controle, para $4 ; 3 ; 2,5$ e $0,2 \mathrm{~kg}$ em suínos que receberam dietas com contaminação de 1, 2, 3 e $4 \mathrm{mg} \mathrm{kg}^{-1}$ de aflatoxinas, durante 4 semanas. Ainda os mesmos autores citaram que os ruminantes são menos sensíveis às aflatoxinas do que os nãoruminantes. Entretanto, a produção (carne, leite e lã), reprodução e crescimento podem ser alterados quando da ingestão de alimentos contaminados durante períodos prolongados.

Segundo Helferich et al. (1986a), o consumo por longo tempo de alimentos contendo aflatoxinas pode promover redução na digestão de celulose, produção de ácidos graxos voláteis e mobilidade de células do rúmen. Observaram também que bovinos alimentados com ração contendo 600 ? g kg-1 de aflatoxinas, durante 155 dias, apresentaram redução de conversão alimentar e de ganho de peso. Fernandez et al. (2000) verificaram que cordeiros de 5 meses de idade que receberam dietas contendo $2 \mathrm{mg} \mathrm{kg}^{-1}$ de aflatoxinas, durante 37 dias, apresentaram uma redução de ganho de peso de $37 \%$, em relação ao grupo controle. 


\subsubsection{Estratégias para o controle de aflatoxinas}

Devido ao impacto das aflatoxinas sobre toda a cadeia alimentar e os sérios riscos à saúde humana e animal, qualquer abordagem para reduzir a atuação tóxica desta molécula, bem como as perdas econômicas por ela ocasionadas, deveriam responder tanto quanto possíveis aos seguintes requisitos: (I) prevenir, destruir, remover ou desintoxicar as aflatoxinas de alimentos ou rações; (II) não produzir ou deixar resíduos tóxicos no produto final; (III) não alterar significativamente as propriedades tecnológicas e nutricionais do alimento ou ração; e (IV) ser técnica e economicamente viável (Piva et al., 1995).

Entre os possíveis agentes que podem ser utilizados para a minização dos danos promovidos pelas aflatoxinas encontram-se os agentes antioxidantes, componentes de alimentos, ervas medicinas, extratos de plantas, ligantes químicos e agentes biológicos (Galvano et al., 2001).

Entre os agentes biológicos que podem ser utilizados para a redução dos danos ocasionados pela ingestão de dietas contaminadas por aflatoxinas, as leveduras tem sido alvo de diversas investigações (Krause et al.,1989; Stanley et al., 1993; Devegowda et al., 1996; Celik et al., 2001; 2003, Parlat et al., 2001; Baptista et al., 2001; 2004)

Para neutralizar a severidade de dieta contendo aflatoxinas, o efeito de Saccharomyces cerevisiae tem sido reconhecido por diminuir o estresse em animais, ser fonte de vitaminas e conter um fator de crescimento, não identificado, que reduz o estresse (Phillips \& Von Tungeln, 1984), conter enzimas e proteína (Crumplen et al., 1989; Krause et al., 1989).

Animais que receberam dietas contaminadas com $5 \mathrm{mg} \mathrm{kg}^{-1}$ de aflatoxinas juntamente com $0,1 \%$ de leveduras vivas, apresentaram ganho de peso $15 \%$ maior do que os animais que receberam dieta contaminada com aflatoxinas sem a suplementação com leveduras vivas (Stanley et al., 1993).

Devegowda et al. (1996), observaram efeitos benéficos de leveduras sobre ganho de peso e resposta imune em animais que receberam dietas contaminadas por aflatoxinas e suplementadas com leveduras. Estes autores, em estudos in vitro", ainda verificaram que a capacidade das leveduras de se ligarem com aflatoxinas depende da dose da toxina, podendo ser superior à $77 \%$. 
Baptista et al. (2001) observaram que a adição de 1\% de leveduras vivas, juntamente com dieta contaminada por 400 ? $\mathrm{g} \mathrm{kg}^{-1}$, promovia a redução na hepato toxidez provocada por esta toxina em ratos, resultando na presença de apenas leves sinais de toxicidade através de análises histopatológicas.

Frangos que receberam dieta com $200 ? \mathrm{~g} \mathrm{~kg}^{-1}$ de aflatoxinas juntamente com leveduras, apresentaram benefícios sobre o ganho de peso, conversão alimentar e mortalidade, resposta imune e o aumento no nível sérico de albumina e proteína (Celik et al., 2003).

Segundo Yiannikouris et al. (2003), a mobilidade da conformação tridimensional da parede celular da levedura é provavelmente importante no evento de adsorção de micotoxinas. Contudo, de acordo com Baptista et al. (2004), o fornecimento de leveduras termolisadas (10g kg1 de ração) e componentes isolados da parede celular de leveduras (10 $\mathrm{kg}^{-1}$ de ração) juntamente com dieta contaminada com 400 ? g kg-1 de aflatoxinas para ratos Wistar não proporcionou a redução dos danos da toxina em nível histológico. Estes autores também observaram que ao adicionarem leveduras vivas ao invés dos seus derivados, sob as mesmas condições, elas eram capazes de reduzir eficientemente os danos histológicos promovidos por esta micotoxina. Os autores sugerem ser necessário que a levedura esteja viva para que esta tenha efeito protetor contra aflatoxicoses.

O mecanismo envolvido na capacidade de leveduras em prevenir os danos promovidos por aflatoxinas ainda é incerto e há várias hipóteses que tentam explicar tal habilidade. De acordo com Stanley et al. (1993); Parlat et al. (2001) e Raju \& Devegowda (2002), o mecanismo envolve a capacidade da levedura em seqüestrar a toxina. Um modelo similar a esse foi proposto por Yiannikouris et al. (2003), que através de ensaios "in vitro" concluíram ser a habilidade de leveduras em reduzir efeitos de micotoxinas, relacionada com a capacidade de adsorver essas moléculas nas paredes celulares e com isso limitar a biodisponibilidade ao organismo.

Para Krause et al. (1989) e Crumplen et al. (1989), as leveduras podem fornecer enzimas, vitaminas ou outros fatores de crescimento não identificados, que reduzem os distúrbios promovidos pelas aflatoxinas. Os estudos conduzidos por Baptista et al. (2001) reforçaram essa última hipótese, uma vez que não foram observados, in vivo", efeito protetor produzido por leveduras mortas e, nem tão pouco de componentes da parede celular de leveduras, 
recomendados com adsorventes, contra os danos promovidos por aflatoxinas em nível histológico.

Baptista et al. (2004), sugerem que, possivelmente, um complexo enzimático esteja envolvido na descontaminação de aflatoxinas pela ação de leveduras, uma vez que somente as leveduras vivas têm demonstrado tal habilidade. Nesse sentido, o complexo enzimático glutationa-s-transferase (GST), o qual as leveduras podem possuir com alta atividade (Alfafara et al., 1992), e é um dos responsáve is pela biotransformação e eliminação de aflatoxinas no organismo animal (Hayes et al., 1991). Por esse motivo, o complexo GST poderia estar envolvido com tal mecanismo de proteção.

\subsubsection{Radiotraçadores no estudo do metabolismo de aflatoxinas}

Existem diversos métodos que podem ser utilizados para julgar a resposta dos mais variados produtos perante às aflatoxinas, cada qual com suas vantagens e desvantagens. Entre os mais utilizados, destacam-se: o cultivo de células "in vitro", bioensaios tradicionais e radiobioensaios (Wogan et al., 1967; Stanley et al., 1993; Shi et al., 1995).

A aplicação de radionuclídeos em estudo do metabolismo de aflatoxinas tem sido muito utilizada, principalmente em investigações envolvendo a excreção e a distribuição da toxina no organismo de animais de diferentes espécies (Wogan et al., 1967; Dalezios et al., 1973; Luthy et al., 1980; Helferich et al., 1986b). O uso desta ferramenta é baseado no princípio de que a rota metabólica de uma molécula radiomarcada é similar ao caminho metabólico da mesma molécula no organismo na ausência do material radioativo, com a diferença que a primeira pode ser facilmente monitorada por possuir um traçador que emite radiações ou partículas e por isso pode ser detectada por onde passa (Bottrill, 1998).

Investigando a distribuição e a excreção de $\mathrm{AFB}_{1}{ }^{14} \mathrm{C}$ em suínos, após aplicação via oral, foi observado que aproximadamente $58 \%$ da radioatividade era eliminada através das fezes e cerca de $12 \%$ via urina em 9 dias após a aplicação. Também foi verificada a presença da molécula e/ou seus metabólitos no sangue em 3 horas após o seu fornecimento e que os maiores níveis destes compostos foram verificados nas primeiras 24 horas após o início do experimento. 
O fígado foi o órgão que mais acumulou radioatividade e, depois deste órgão, os rins foram aqueles que mais acumularam a radiomolé cula e seus subprodutos (Luthy et al., 1980).

Helferich et al. (1986b), aplicaram AFB $1{ }^{14} \mathrm{C}$ em cabras no período de lactação, via oral, e observaram que em 120 h após a aplicação, aproximadamente 30,9; 1,1 e 52,3\% da radioatividade havia sido eliminada via urina, leite e fezes, respectivamente. Nesse estudo também foi observado que 0 fígado retinha $4,9 \%$ da dose ministrada e que outros órgãos continham menos de $0,1 \%$ da dose inicial em cinco dias depois de ministrar a aflatoxina radioativa. Além disso, no mesmo período a radioatividade no tecido muscular era cerca de 0,5\% da dose original. Estes autores conduziram, simultaneamente, outro estudo utilizando ratas em lactação e verificaram que em $120 \mathrm{~h}$ depois do início do radioensaio, a urina, as glândulas mamárias com leite e as fezes continham 9; 3 e 65\% da radioatividade aplicada, respectivamente.

Kumagai (1989), investigando a absorção e a excreção de $\mathrm{AFB}_{1}{ }^{3 \mathrm{H}}$ em ratos, pôde-se observar que a taxa de secreção biliar de ${ }^{3} \mathrm{H}$ foi maior quando a molécula marcada foi liberada no intestino delgado do que quando foi injetada direto no estômago. O autor também pode notar que a taxa de absorção de $\mathrm{AFB}_{1}$ e/ou seus metabólitos nos vários sítios do intestino mudavam com a idade e estágio do ciclo reprodutivo do animal.

Segundo Ewaskiewicz et al. (1991), após a aplicação de baixas doses de $\mathrm{AFB}_{1}{ }^{3} \mathrm{H}(0,70$ $? \mathrm{~g} \mathrm{~kg}^{-1}$ ) em ratos Wistar, a presença de radioatividade no sangue, coração e fígado acontecia rapidamente, em menos de $2 \mathrm{~h}$. Após esta fase, a cinética da radiomolécula era alterada e 0 aumento era mais lento no período de 2 a $12 \mathrm{~h}$. Estes autores também verificaram que a maior quantidade da radioatividade encontrada ro sangue estava ligada não covalentemente com proteínas.

Dalezios et al. (1973), ministrando $\mathrm{AFB}_{1}{ }^{14} \mathrm{C}$ para macacos Resus, por via oral, notaram que em 7 dias após a aplicação, a eliminação da radioatividade resultou em 41\% e 40\% da dose aplicada, nas de fezes e nas urinas, respectivamente. Também verificaram que 0 maior percentual deste material radioativo foi eliminado nas primeiras $24 \mathrm{~h}$ após a administração da toxina. Contudo, encontraram níveis detectáveis de radioatividade na urina cinco semanas após o seu fornecimento. Estes autores ainda observaram que a aflatoxina e/ou seus metabólitos eram absorvidos rapidamente no trato gastrintestinal e que em 4 horas após a introdução do 
radiotraçador no organismo dos animais a radiação ionizante no sangue já era detectada, a qual também foi encontrada no sangue em cinco semanas após o início do ensaio. Nesse estudo também foi relatado que o fígado foi o órgão que retinha os maiores níveis de radioatividade, aproximadamente $4,2 \%$ da dose ministrada após sete dias. Além disso, neste órgão, a diminuição da radioatividade foi lenta e, em cinco semanas ainda continha cerca de $1 \%$ da dose aplicada.

Segundo Wogan et al. (1967), \&s ratos são animais que apresentam habilidade de eliminar eficientemente $\mathrm{AFB}_{1}$ e seus metabólitos após receberem uma dose simples desta molécula. Durante as primeiras $24 \mathrm{~h}$ após ter recebido aflatoxina radiomarcada, aproximadamente $75 \%$ da dose aplicada foi excretada via urina e fezes, sendo $20 \%$ através da urina e mais de $50 \%$ junto com as fezes. O composto marcado foi encontrado nos tecidos em 30 minutos após o seu fornecimento. Os níveis de radioatividade observados no fígado foram de $5 \mathrm{a}$ 15 vezes maiores do que aqueles encontrados em outros órgãos. Em 24h após receber a aflatoxina radiomarcada, o fígado dos animais continham cerca de $10 \%$ da dose ingerida Eles também observaram que durante as primeiras oito horas após a introdução da radiomolécula de aflatoxinas quase todo o material radioativo que era excretado através da urina e que as fezes contribuíam com apenas uma pequena parcela. Contudo, a eliminação via fezes aumentava rapidamente no intervalo de 8 a 15h, de tal forma que em $24 \mathrm{~h}$, mais de $50 \%$ da radioatividade excretada se encontrava nas fezes.

A presença de radioatividade proveniente de $\mathrm{AFB}_{1}{ }^{14} \mathrm{C}$ no intestino delgado de ratos ocorria em cerca de 30 minutos após o seu fornecimento via oral e, em $2 \mathrm{~h}$ praticamente todo material radioativo que era eliminado através das fezes já estava presente neste segmento. Este comportamento da molécula levou os autores a sugerirem que os materiais presentes nas fezes eram excretados pela bile. E ainda, em ratos, decorridos 30 minutos da aplicação de $\mathrm{AFB}_{1}{ }^{14} \mathrm{C}$ por via oral, os rins continham aproximadamente 5\% , o fígado 17\% e a carcaça eviscerada $27 \%$ do material radioativo recuperado. Durante os 90 minutos subseqüentes a radioatividade diminuiu rapidamente, de modo que atividade específica do material remanescente nos rins era menor do que $1 \%$ e que o fígado continha cerca de $10 \%$ do material recuperado. Os baixos níveis de radioatividade foram mantidos nos rins durante as outras $22 \mathrm{~h}$ do estudo. Os níveis de material marcado na carcaça diminuíram de maneira mais lenta do que nos rins e, em 24 h após 
o seu fornecimento, cerca de $8 \%$ da radioatividade se encontrava nesta porção. No fígado, 0 nível continuou caindo durante o intervalo de 2 a $24 \mathrm{~h}$ após ministrar a $\mathrm{AFB}_{1}{ }^{14} \mathrm{C}$ e, ao término do radioensaio, a quantidade de molécula radioativa remanescente era de aproximadamente 6,5\% do total recuperado. Os outros tecidos apresentaram teores de material radioativo menores que $0,5 \%$ da radioatividade recuperada em qualquer momento da coleta de dados (Wogan et al., 1967). 


\section{Comparação entre duas linhagens de Saccharomyces cerevisiae no controle de aflatoxicoses}

\section{Resumo}

Leveduras são microrganismos unicelulares, não patogênicos, bastante utilizados para a obtenção de produtos de interesse humano a partir de processos biotecnológicos. Os objetivos deste trabalho foram: avaliar duas linhagens de Saccharomyces cerevisiae na minimização de aflatoxicoses e verificar o efeito de diferentes concentrações de leveduras na redução dos danos promovidos por aflatoxinas. Foram elaboradas uma dieta livre de aflatoxinas e seis dietas contaminadas com 400 ? g kg-1 de aflatoxinas, das quais uma a controle com aflatoxinas e cinco com a adição de duas linhagens de leveduras vivas. Foram adicionadas leveduras da linhagem Y1026, nas concentrações de 0,5\%; 1,0\% e 5,0 \% e da linhagem Y904 (na concentração de 1,0\%) na ausência ou presença de 1000 ppm de metionina mais 1000 ppm de cisteina. O bioensaio foi conduzido utilizando ratos Wistar, de 21 dias de idade e cerca de 60 gramas cada, durante 28 dias. Os animais foram distribuídos em delineamento inteiramente casualizado, com 5 repetições por tratamento. Os parâmetros para avaliação foram: consumo médio, ganho de peso médio, conversão alimentar, provas bioquímicas, órgãos internos e o tecido hepático. Os resultados demonstraram que os animais dos diferentes tratamentos não apresentaram diferenças estatísticas significativas para os seguintes parâmetros: ganho de peso médio, consumo médio, conversão alimentar e provas bioquímicas. 0 tecido hepático dos animais submetidos ao tratamento controle com aflatoxinas apresentaram sinais evidentes de hepatotoxidez, com desorganização celular e necrose de hepatócitos. Por outro lado, os animais que receberam tratamentos suplementados com diferentes concentrações de leveduras e das duas linhagens apresentaram sinais leves de toxicidade, com pouca desorganização celular e, 
ficaram semelhantes aos do controle sem aflatoxinas. Conclui-se que as linhagens de Saccharomyces cerevisiae Y1026 e Y904 apresentaram habilidade de minimizar aflatoxicoses e que as diferentes concentrações das leveduras avaliadas apresentaram capacidade de reduzir os danos induzidos por aflatoxinas.

\section{Comparison between two strains of Saccharomyces cerevisiae to control aflatoxicosis}

\section{Summary}

Yeasts are unicellular microorganisms, no pathogenic, quite used for obtaining products of human interest starting from biotechnological processes. The aim this study was to evaluate the ability of two strains from Saccharomyces cerevisiae (Y1026 and 904) to minimize aflatoxicosis. Aflatoxinfree diet and six contaminated diets with 400 ? $\mathrm{g} \mathrm{kg}^{-1}$ aflatoxin were formulated with an aflatoxin control and five diets were supplemented with live yeast and amino acids. A bioassay with 21day-old 60-g Wistar rats was conducted for 28 days. Results showed that the animals from different groups did not show statistical differences for the following parameters: average consumption; average weight gain; eed conversion, and enzymatic analyses. The hepatic tissue from the animals fed with the aflatoxin control diet showed evidence of hepatoxicity. On the other hand, animals that were fed diets supplemented with different concentrations of yeast cells showed reduced signs of toxicity, with less tissue disorganization. To further the evaluation the results a second yeast strain (Y904) was tested at the 1.0\% concentration and at 1.0\%+1000 ppm methionine +1000 ppm cysteine. These results were similar to those of the aflatoxin-minus control ration and showed that the yeast cells could reduce the damage caused by aflatoxins. In conclusion, Saccharomyces cerevisiae strains Y1026 and Y904 were both capable of minimizing aflatoxicosis.

\subsection{Introdução}

As leveduras são organismos unicelulares, facilmente manipuláveis, normalmente não patogênicos, capazes de crescer em várias fontes de carbono e de fornecer grande quantidade 
de biomassa em tempo relativamente pequeno. 0 conhecimento já existente relativo à fisiologia, bioquímica e genética, faz deste microrganismo uma das principais ferramentas da biotecnologia, que devido às suas propriedades biológicas, apresenta um grande número de aplicações industriais (Angier, 1986; Beudeker, 1990).

Entre as diversas possibilidades de aplicação das leveduras destaca-se a sua utilização como suplemento alimentar, através da adição de suas células vivas, visando afetar beneficamente 0 hospedeiro e promover um melhor balanço na microbiota intestinal. 0 fornecimento de probiótico pode trazer vários benefícios ao indivíduo, entre os quais, aumento da resistência a doenças infecciosas; diminuição da duração de diarréia; redução da pressão sang üínea; estímulo da fagocitose por leucóticos periféricos do sangue; redução de sensibilidade a alergias; regressão de tumores; redução da produção de carcinogênicos e co-carcinogênicos; aumento da taxa de crescimento; melhoria da eficiência alimentar e aumento de produção (Bloksma et al., 1979; Kato et al., 1981; Fernandes et al., 1987; Sawada et al., 1990; Fuller, 1992; Perdigon \& Alvarez, 1992; Saavedra et al., 1994). Com este enfoque, Baptista et al. (2001), relataram a utilização da evedura Saccharomyces cerevisiae na forma de probiótico como promissor agente para a redução dos danos promovidos por aflatoxinas.

As aflatoxinas por sua vez, são metabólitos secundários, tóxicos, produzidos por algumas linhagens de Aspergillus flavus e A. parasiticus, além de outras espécies como A. nomius (Heathcote, 1984; Frisvad \& Thrane, 1996). Sob condições favoráveis de temperatura e umidade, estes fungos podem crescer em certos alimentos e produzir aflatoxinas (Fortnum, 1986; Lillehoj, 1986).

No mundo todo, há uma crescente conscientização das sérias conseqüências que a ingestão de concentrações elevadas ou crônicas de aflatoxinas pode causar à saúde humana e dos animais (FAO, 1993). Bioquimicamente, as aflatoxinas podem afetar os metabolismos de: energia, carboidratos, lipídios, ácidos nucléicos e proteínas. Os efeitos biológicos podem ser carcinogenicidade, mutagenicidade, teratogenicidade, hepatotoxicidade e aflatoxicoses (Ellis et al., 1991; Bradburn \& Coker, 1993).

O impacto econômico resultante da contaminação por aflatoxina ocorre em todos os níveis da produção de alimentos, incluindo produção animal e vegetal, processamento e distribuição de alimentos (Charmley et al., 1995; Galvano et al., 2001). A facilidade e freqüência 
com que as aflatoxinas contaminam os produtos agrícolas, e ao mesmo tempo, a exposição de animais a níveis crônicos destes compostos químicos, via dieta contaminada, podem ser as principais diferenças entre o lucro e o prejuízo para atividade agroindustrial (Jones et al., 1982; Nichols, 1983; Hamilton, 1984; Kubena et al., 1990).Os objetivos desta pesquisa foram investigar a capacidade de duas linhagens de leveduras para reduzir os danos promovidos por aflatoxinas e verificar o efeito de diferentes concentrações de levedura para minimizar aflatoxicoses.

\subsection{Material e métodos}

\subsubsection{Animais e tratamentos}

Ratos albinos (Rattus norvegicus), da linhagem Wistar, com 21 a 25 dias de idade e pesando aproximadamente 60 gramas cada, foram distribuídos em 35 gaiolas, separados em 7 grupos de tratamentos com 5 animais cada, para avaliar a interação das linhagens Y904 e Y1026 de $S$. cerevisiae sobre os efeitos prejudiciais de aflatoxinas em animais de laboratório. 0 delineamento experimental utilizado foi o inteiramente casualizado, consistindo de sete dietas, entre as quais: 0 controle sem aflatoxinas (T1) - dieta livre de aflatoxinas - em níveis não detectáveis (NND), ? 0,5 ? $\mathrm{g} \mathrm{kg}^{-1}$; e, seis dietas contaminadas com 400 ? g kg-1 de aflatoxinas; das quais o controle com aflatoxinas (T2) e as demais suplementadas com leveduras, conforme descrito a seguir: dieta suplementada com 0,5\% de levedura Y1026 (T3); dieta suplementada com 1,0\% de levedura Y1026 (T4); dieta suplementada com 5,0\% de levedura Y1026 (T5); dieta suplementada com 1,0\% de levedura Y904 (T6) e dieta suplementada com 1,0\% de levedura Y904 enriquecida com metionina e cisteina (1000 ppm) (T7).

Os animais foram alimentados com dieta à base de proteína, carboidratos, lipídios, fibras, mistura mineral e mistura vitamínica, (dieta AIN-93G),conforme descrita por Reeves et al. (1993), durante 28 dias, com o fornecimento de água "ad libitum" e 15 gramas de dieta a cada animal, diariamente. A contaminação das dietas foi realizada pela adição de amendoim contendo aflatoxinas naturais. As leveduras foram aplicadas às dietas após a contaminação. Todas as dietas foram estocadas em câmara fria até seu o fornecimento aos animais. 


\subsubsection{Viabilidade de leveduras}

Foram utilizadas leveduras da espécie Saccharomyces cerevisiae, das linhagens Y904 e Y1026, as quais foram aplicadas na forma desidratada viva. A viabilidade das células de leveduras foi determinada pelo método de coloração com azul de metileno $(0,1 \%)$, conforme descrito por Pierce (1970). As leveduras apresentaram viabilidades médias de 72\% (Y1026) e de 98\% (Y904), no momento da instalação do experimento.

\subsubsection{Determinação de aflatoxinas}

A determinação de micotoxinas (aflatoxinas, zearalenona, ocratoxina $A$ e deoxinivalenol) foi feita usando cromatografia de camada delgada, de acordo com as metodologias descritas por Soares \& Rodrigues-Amaya (1989) e Eppley et al. (1986), com adaptações, como a quantificação feita através de cromatografia bi-direcional, onde o limite de deteç̧ão para as quatro aflatoxinas foi de $0,5 ? \mathrm{~g} \mathrm{~kg}^{-1}$. Não foi detectada a presença de zearalenona, ocratoxina A e deoxinivalenol.

\subsubsection{Avaliação dos alimentos}

O consumo médio foi calculado subtraindo-se a quantidade de alimento remanescente no comedouro daquela fornecida ao animal, em intervalos de 2 ou 3 dias e, dividindo-se 0 valor obtido por 2 ou 3. Nestes mesmos intervalos, os animais foram pesados para o cálculo do ganho de peso médio. E, a conversão alimentar foi obtida dividindo-se o consumo de alimentos pelo ganho de peso do animal.

\subsubsection{Provas bioquímicas e biometria de órgãos internos}

Após 28 dias de ensaio, os animais foram anestesiados em câmara saturada com halotano. Em seguida, o sangue foi coletado e o soro sangüíneo obtido por centrifugação com $1200 \mathrm{~g}$ por minutos durante 20 minutos, em tubos pré-condicionados. As amostras de soro foram usadas para a realização das provas bioquímicas, das quais foram obtidas as atividades das seguintes enzimas: Aspartato aminotransferase (AST); Fosfatase alcalina (FA) e Alanina aminotransferase (ALT). A detecção das atividades específicas destas enzimas foi realizada 
utilizando um analisador automático Theinon RA-100 e os kits comerciais da BioSystems Reagents \& Instruments Co, específicos para cada enzima.

Também foram extraídos e pesados os órgãos internos (fígado, rins e coração) e o peso relativo de stes órgãos por $100 \mathrm{~g}$ de peso vivo foi encontrado multiplicando-se o peso do total do órgão por 100 e, dividindo -se o valor obtido pelo peso vivo do animal. Além disso, fragmentos dos fígados foram fixados em solução de formol 10\% e utilizados para o estudo histológico.

\subsubsection{Estudo histopatológico}

A partir de cada uma das peças de tecido hepático dos 35 animais, foram preparadas três lâminas histológicas, conforme os procedimentos descritos por Pacheco (1981) e foram coradas com hematoxilina e eosina $(\mathrm{HE})$. Após o preparo, o estudo histopatológico das lâminas foi realizado ao microscópio de luz, em aumento de 16 x 1,25 x 10 (200x).

O tecido hepático de animais que receberam dieta livre de aflatoxinas foi adotado como padrão de referência para isento de hepatotoxidez.

\subsubsection{Estatística}

Os dados foram analisados pelo programa SAS (Herzberg, 1990) para a determinação da análise de variância e a comparação entre médias foi realizada usando-se o teste de Tukey com um nível de confiança de $95 \%$.

\subsection{Resultados e discussão}

\subsubsection{Avaliação alimentar e peso relativo de órgãos internos}

Os animais submetidos aos diferentes tratamentos não apresentaram diferenças estatisticamente significativas $(P<0,05)$ com relação aos parâmetros consumo diário médio (CDM) e ganho de peso médio (GPM), conforme pode ser observado na Tabela 1. Estes resultados estão de acordo com aqueles encontrados por Baptista et al. (2002), os quais verificaram que ratos albinos, da linhagem Wistar, quando submetidos à dietas contaminadas por aflatoxinas, não apresentaram redução do consumo de alimentos e também não demonstraram 
diminuição no ganho de peso. Estes resultados podem ser explicados pelo fato de ratos serem animais tolerantes aos efeitos das aflatoxinas (Barnes \& Butler, 1964).

Embora outros autores tenham relatado que os sintomas clínicos mais comuns da ingestão de aflatoxinas sejam anorexia, diminuição do ganho de peso, diminuição da utilização do alimento (Dickens \& Jones, 1963; Edds \& Bortel, 1983; Huff et al., 1986; Kubena et al., 1990); essas divergências podem ser atribuídas a diferenças experimentais, tais como: espécies utilizadas; tempo de exposição dos animais às toxinas e doses ministradas.

Em relação à conversão alimentar, observa-se que os animais que receberam os diferentes tratamentos não apresentaram diferenças estatísticas $(P<0,05)$ entre si. Estes resultados indicam que a ingestão de aflatoxinas pelos animais dos diferentes grupos de tratamentos não interferiu na conversão alimentar dos mesmos, uma vez que os resultados de conversão alimentar dos animais dos grupos controles, T1 e T2, também foram estatisticamente semelhantes.

Tabela 1 - Parâmetros de avaliação de consumo e peso relativo de órgãos internos em ratos expostos ou não às aflatoxinas.

\begin{tabular}{|c|c|c|c|c|c|c|}
\hline \multirow{3}{*}{ Tratamentos } & \multirow{2}{*}{$\begin{array}{l}\text { Consumo de } \\
\text { Alimento } \\
\text { Médio }\end{array}$} & \multirow{2}{*}{$\begin{array}{c}\text { Ganho de } \\
\text { Peso } \\
\text { médio }\end{array}$} & \multirow{2}{*}{$\begin{array}{c}\text { Conversão } \\
\text { Alimentar } \\
\text { média }\end{array}$} & \multicolumn{3}{|c|}{$\begin{array}{l}\text { Peso relativo por } 100 \\
\text { gramas de peso vivo }\end{array}$} \\
\hline & & & & Fígado & Rins & Coraçãa \\
\hline & (g/dia) & (g/dia) & & (g) & $(g)$ & (g) \\
\hline Dieta livre de aflatoxinas (T1) & 11,8 & 5,5 & $2,2 \mathrm{~b}$ & 8,1 & 0,73 & 0,87 \\
\hline $\mathrm{T} 1+$ com $400 ? \mathrm{~g} \mathrm{~kg}^{-1}$ de aflatoxinas (T2) & 11,4 & 5,5 & $2,1 \mathrm{~b}$ & 8,5 & 0,78 & 0,91 \\
\hline T2 + 0,5\% da levedura Y1026 (T3) & 11,9 & 5,2 & $2,5 a b$ & 8,6 & 0,76 & 0,89 \\
\hline $\mathrm{T} 2+1,0 \%$ da levedura Y1026 (T4) & 14,9 & 4,5 & $2,4 a b$ & 7,6 & 0,61 & 0,94 \\
\hline T2 + 5,0\% da levedura Y1026 (T5) & 10,3 & 4,2 & $2,5 a b$ & 7,3 & 0,66 & 0,80 \\
\hline T2 + 1,0\% da levedura Y904 (T6) & 12,7 & 5,6 & $2,3 \mathrm{~b}$ & 7,9 & 0,60 & 0,83 \\
\hline T6 + 1000 ppm de met +1000 ppm de cist (T7) & 13,3 & 5,3 & $2,5 a b$ & 7,9 & 0,60 & 0,83 \\
\hline CV(\%) & 23,6 & 15,1 & 26,1 & 19,4 & 17,0 & 18,4 \\
\hline
\end{tabular}

Médias seguidas por letras distintas, nas colunas, diferem estatisticamente entre si em nível de significância de $5 \%$ através do teste de Tukey.

Os pesos relativos dos órgãos internos (fígado, coração e rins), dos animais submetidos aos diferentes tratamentos não diferiram estatisticamente $(P<0,05)$ (Tabela 1); indicando que os efeitos do nível de contaminação e do tempo de exposição dos animais às aflatoxinas não foram suficientes para provocar modificações que pudessem ser observadas pela mudança no peso relativo destes órgãos nos indivíduos avaliados. 
Estes resultados não são semelhantes a aqueles obtidos por Stanley et al. (1993), os quais verificaram que os pesos relativos dos órgãos internos (fígado, coração e rins) de frangos que receberam dietas contaminadas com $5 \mathrm{mg} \mathrm{kg}^{-1}$ de aflatoxinas, durante 28 dias, foram maiores do que os pesos relativos destes órgãos, em animais que receberam dieta livre destas toxinas, no mesmo período. Estas diferenças podem ser atribuídas às diferentes quantidades de aflatoxinas ministradas aos animais, uma vez que, na investigação conduzida por Stanley et al. (1993), os animais receberam $5 \mathrm{mg} \mathrm{kg}^{-1}$ de aflatoxinas, ao passo que, no presente estudo, os ratos foram expostos a uma dose de 400 ? $\mathrm{g} \mathrm{kg}^{-1}$ de aflatoxinas; e, segundo Smith \& Moss (1985), os ratos apresentam sensibilidade às aflatoxinas diferente dos frangos.

\subsubsection{Provas bioquímicas}

Em relação às provas bioquímicas, pode-se verificar que as médias de atividade das enzimas alanina aminotransferase (ALT), aspartato aminotransferase (AST) e fosfatase alcalina (FA) e os níveis de albumina (ALB) não diferiram estatisticamente $(P<0,05)$ entre os animais que receberam os diferentes tratamentos. Estes resultados estão de acordo com os encontrados por Celik et al. (2001), os quais ministrando baixas doses de aflatoxinas (100? $\mathrm{g} \mathrm{kg}^{-1}$ de AFB1 $)$, não observaram diferenças nas atividades das enzimas AST, ALT e FA entre animais que receberam ou não a dieta com a toxina.

Contudo, há relatos contraditórios a respeito dos efeitos das aflatoxinas sobre a atividade destas enzimas. Gawai et al. (1992) relataram o aumento da atividade das enzimas AST e ALT em ratos que receberam $1,5 \mathrm{mg}$ de aflatoxinas por $\mathrm{kg}$ de peso corporal, enquanto que Stanley et al. (1993) observaram que os animais que receberam dietas contendo $5 \mathrm{mg} \mathrm{kg}^{-1}$ de aflatoxinas apresentaram redução na atividade das enzimas ALT, AST e lactato desidrogenase.

Tabela 2 - Parâmetros bioquímicos séricos em ratos expostos ou não à aflatoxina.

\begin{tabular}{lccc}
\hline \multicolumn{1}{c}{ Tratamentos } & $\begin{array}{c}\text { AST } \\
(\mathrm{u} / \mathrm{L})\end{array}$ & $\begin{array}{c}\text { ALT } \\
(\mathrm{u} / \mathrm{L})\end{array}$ & $\begin{array}{c}\mathrm{FA} \\
(\mathrm{u} / \mathrm{L})\end{array}$ \\
\hline Dieta livre de aflatoxinas (T1) & 190,0 & 39,9 & 460,3 \\
T1 + com 400 ? g kg-1 de aflatoxinas (T2) & 165,8 & 39,6 & 612,0 \\
T2 + 0,5\% da levedura Y1026 (T3) & 181,7 & 42,8 & 583,6 \\
T2 + 1,0\% da levedura Y1026 (T4) & 153,6 & 40,1 & 545,6 \\
T2 + 5,0\% da levedura Y1026 (T5) & 143,6 & 45,5 & 682,2 \\
T2 + 1,0\% da levedura Y904 (T6) & 115,3 & 30,2 & 509,2 \\
T6 + 1000 ppm de met + 1000 ppm de cist (T7) & 144,8 & 37,9 & 585,6 \\
CV (\%) & $\mathbf{3 1 , 4}$ & $\mathbf{4 6 , 1}$ & $\mathbf{2 6 , 6}$ \\
\hline
\end{tabular}




\subsubsection{Diagnóstico histopatológico}

As análises histopatológicas foram realizadas com exame de 15 lâminas disponíveis para cada tratamento e em cada tratamento foi selecionada uma fotomicrografia que representasse esse conjunto. De modo que, a seguir serão ilustrados, apresentados e discutidos os resultados obtidos no estudo histopatológico dos animais de cada tratamento.

A Figura 2 ilustra o tecido hepático de um animal que recebeu dieta livre de aflatoxinas (T1). Através desta figura pode-se observar que a organização celular está normal, sem a presença de degeneração e de necrose celular, além das células em degeneração fisiológica. Os resultados estão de acordo com o previsto, uma vez que os animais deste grupo não ingeriram aflatoxinas e, portanto, não deveriam apresentar hepatotoxidez. Por isso, o tecido hepático dos animais do grupo T1 foi adotado como padrão de referência para investigar se os animais submetidos aos demais tratamentos apresentaram ou não os danos promovidos pelas aflatoxinas e, se os tratamentos com leveduras foram capazes ou não de diminuir os danos de tais toxinas.

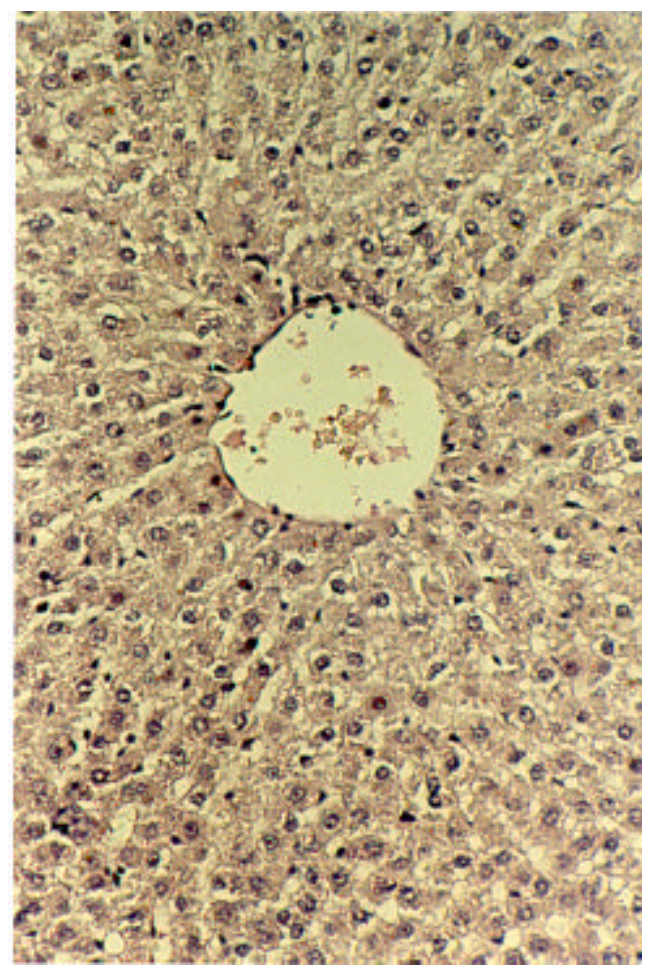

Figura 2 - Fotomicrografia do tecido hepático de rato que recebeu alimentação livre de aflatoxinas (aumento de 200X).

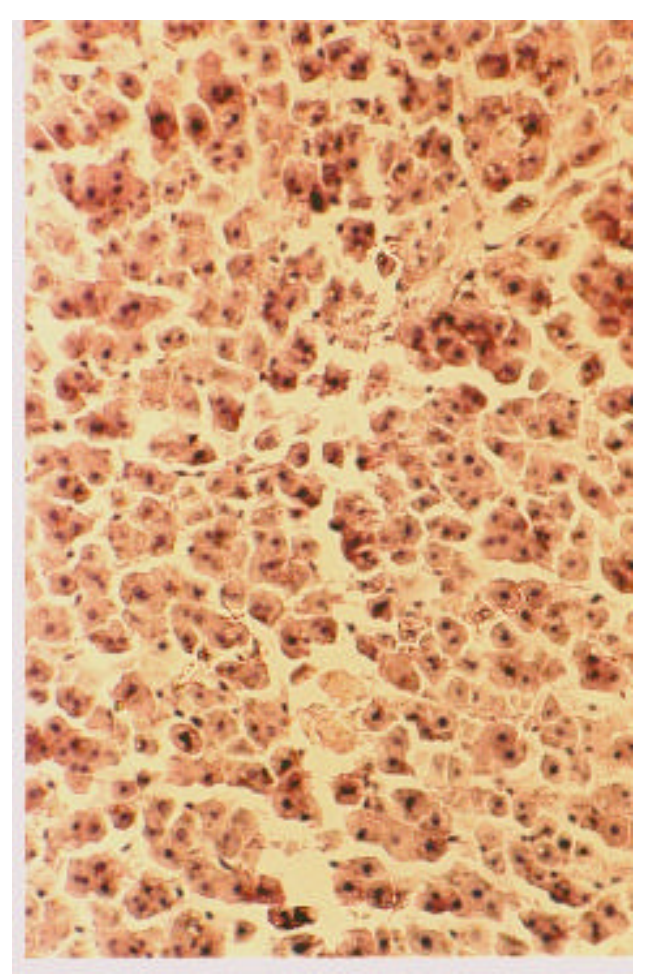

Figura 3 - Fotomicrografia do tecido hepático de rato que recebeu alimentação contaminada com 400 ? $\mathrm{g} \mathrm{kg}^{-1}$ de aflatoxinas (aumento de 200x). 
A Figura 3 apresenta 0 aspecto do tecido hepático de animais que recebe ram dieta contaminada com aflatoxinas, na concentração de 400 ?g kg-1 (T2). Pode-se verificar que 0 tecido apresenta grande perda da organização celular, com alteração da estrutura hepática normal. Essas alterações se traduzem em perda da organização dos capilares sinusóides e desestruturação das travas celulares. Os hepatócitos apresentam sinais de degeneração, retenção de pigmentos e necrose.

Os resultados obtidos estão de acordo com Heathcote \& Hibbert (1978); Baptista et al. (2002) e Celik et al. (2003), os quais observaram desorganização celular, com proliferação de ductos biliares, necrose do parênquima hepático, vacuolização, hepatócitos inchados, degeneração gordurosa e retenção de pigmentos ao examinarem es tecidos hepáticos dos animais que receberam dietas contaminadas por aflatoxinas. As informações obtidas no presente trabalho indicam que a dose de aflatoxinas ministrada e o tempo de exposição dos animais às mesmas foram suficientes para manifestar hepatotoxidez nos animais.

Observando-se as Figuras 4, 5 e 6, pode-se verificar que os animais submetidos aos tratamentos T3, T4 e T5, respectivamente, apresentaram tecidos hepáticos com leve grau de desorganização celular. Também se nota que as células não apresentaram sintomas de necrose e nem de degeneração, além das ocorrências fisiológicas normais.

Através destes resultados observase que os animais que receberam suplementação com a levedura, da linhagem Y1026, nas concentrações de 0,5\%, 1,0\% ou 5,0\% apresentaram pronunciada redução dos danos promovidos pelas aflatoxinas aos hepatócitos quando comparados com os animais do grupo controle que recebeu dieta basal mais aflatoxinas (T2). Além disso, a histologia hepática destes animais revela características bastante similares àquelas do fígado de animais que receberam dieta livre de aflatoxinas (Figura 2). Isso reforça a hipótese de que as leveduras vivas são capazes de reduzir aflatoxicoses.

Estes resultados corroboram com aqueles encontrados por Stanley et al. (1993); Baptista et al. (2001); Parlat et al. (2001) e Celik et al. (2003), os quais também observaram redução nos danos promovidos por aflatoxinas em animais que receberam leveduras juntamente com dietas contaminadas por esta micotoxinas. 


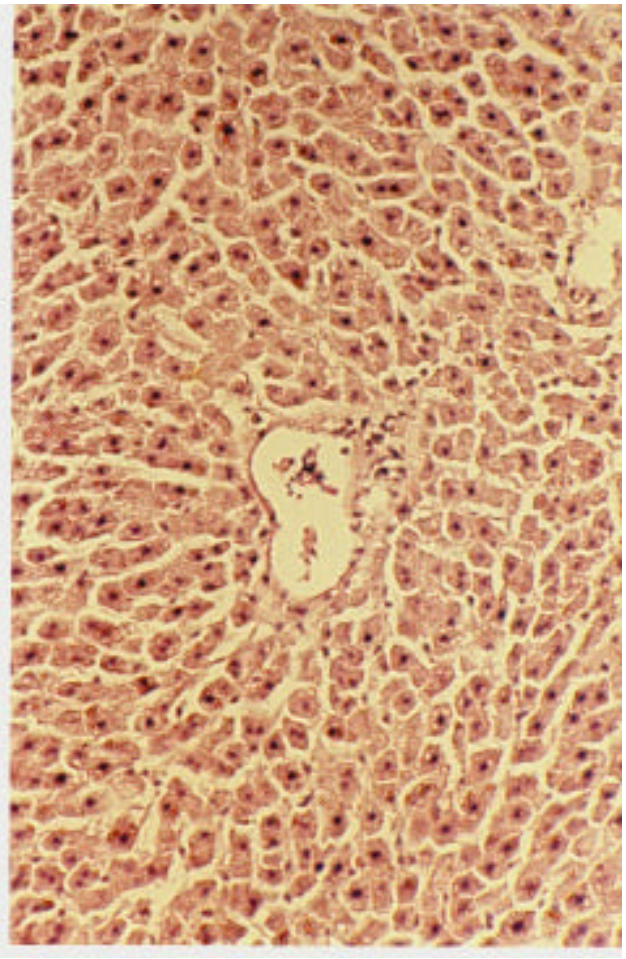

Figura 4 - Fotomicrografia do tecido hepático de rato que recebeu alimentação contaminada com 400 ?g kg-1 de aflatoxinas $+0,5 \%$ de levedura da linhagem Y1026 (aumento de 200x).

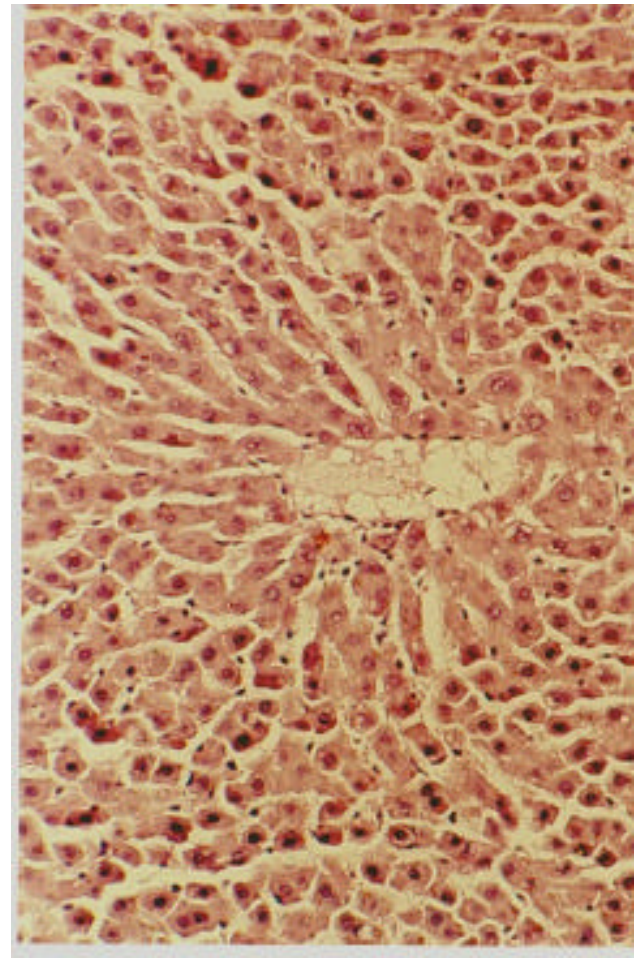

Figura 5 - Fotomicrografia do tecido hepático de rato que recebeu alimentação contaminada com 400 ? $\mathrm{g} \mathrm{kg}^{-1}$ de aflatoxinas $+1,0 \%$ de levedura da linhagem Y1026 (aumento de 200x).

Também foi observado que, nas condições em que foi conduzida esta investigação, não ocorreram diferenças estatisticamente significativas na eficácia do controle de aflatoxinas pela levedura da linhagem Y1026, nas diferentes concentrações de células avaliadas e que todas as doses apresentaram habilidade de minimizar aflatoxicoses, podendo, ainda, nomear a menor dose como a indicada para a minimização dos prejuízos oriundos da ingestão de aflatoxinas, sendo tal dose, a mais indicada do ponto de vista econômico.

Contudo, é importante ressaltar a necessidade de se conduzir estudos com doses mais elevadas de aflatoxinas e/ou que o tempo de exposição dos animais à estas toxinas seja maior, a fim de determinar qual é a melhor concentração de leveduras a ser utilizada para tal finalidade.

A Figura 7 demonstra 0 tecido hepático de um dos animais que receberam dieta contaminada por aflatoxinas juntamente com $1 \%$ da levedura Y904, através da qual pode-se notar que os animais submetidos ao tratamento T6 apresentaram tecidos hepáticos com sinais leves de intoxicação, com pouca desorganização celular e necrose celular. Este quadro clínico difere muito 
daquele apresentado pelos animais submetidos ao tratamento T2 e, đém disso, é bastante semelhante ao observado nos animais que receberam a dieta livre de aflatoxinas. Isso indica que a levedura Y904, na concentração ministrada, foi capaz de diminuir os danos promovidos pela ingestão das aflatoxinas.

$\mathrm{Na}$ literatura não foram encontrados relatos do uso desta linhagem de levedura para a referida finalidade. No entanto, os resultados encontrados são semelhantes aos relatados por Stanley et al. (1993); Parlat et al. (2001) e Baptista et al. (2002), os quais utilizando a linhagem de levedura Y1026 verificaram que esta era capaz de amenizar os danos ocasionados pela presença de aflatoxinas. Estes resultados podem indicar que a linhagem de Saccharomyces cerevisiae utilizada não venha a ser 0 fator mais importante para a prevenção de aflatoxicoses pelo uso de células vivas, já que as pesquisas utilizando diferentes linhagens revelaram resultados positivos semelhantes. Talvez o número de células vivas e o processo industrial de obtenção da levedura sejam os fatores mais relevantes, uma vez que estudos conduzidos por Stanley et al. (1993) recomendaram a utilização de leveduras vivas. Essas informações foram reforçadas mais tarde por Baptista et al. (2000), os quais verificaram "in vivo" o efeito protetor de leveduras vivas contra aflatoxinas e também observaram que a levedura termolisada não tinha tal habilidade. 


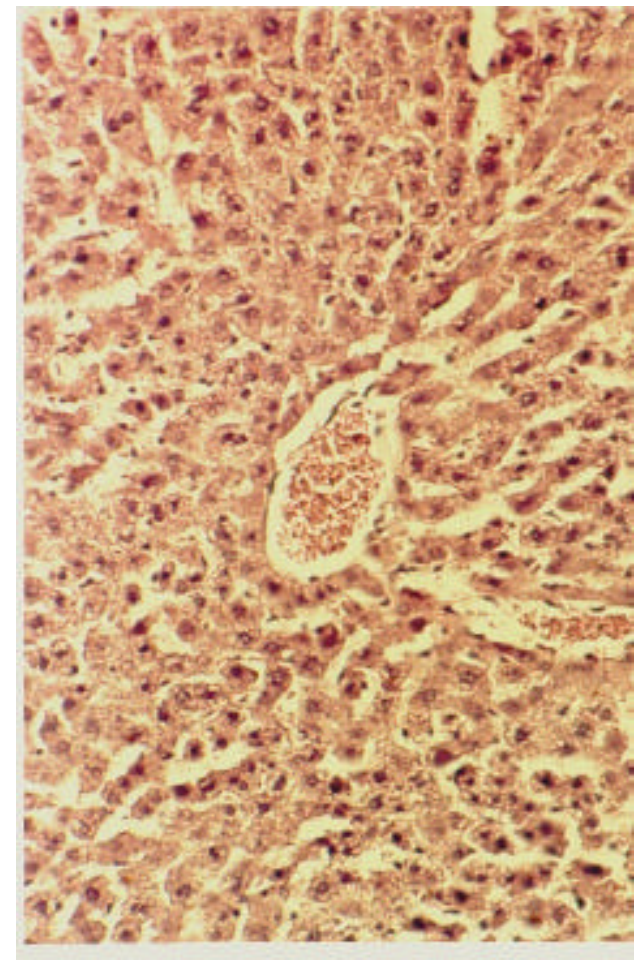

Figura 6 - Fotomicrografia do tecido hepático de rato que recebeu alimentação contaminada com 400 ? g kg-1 de aflatoxinas + $5,0 \%$ de levedura da linhagem Y1026 (aumento de $200 \mathrm{x}$ )

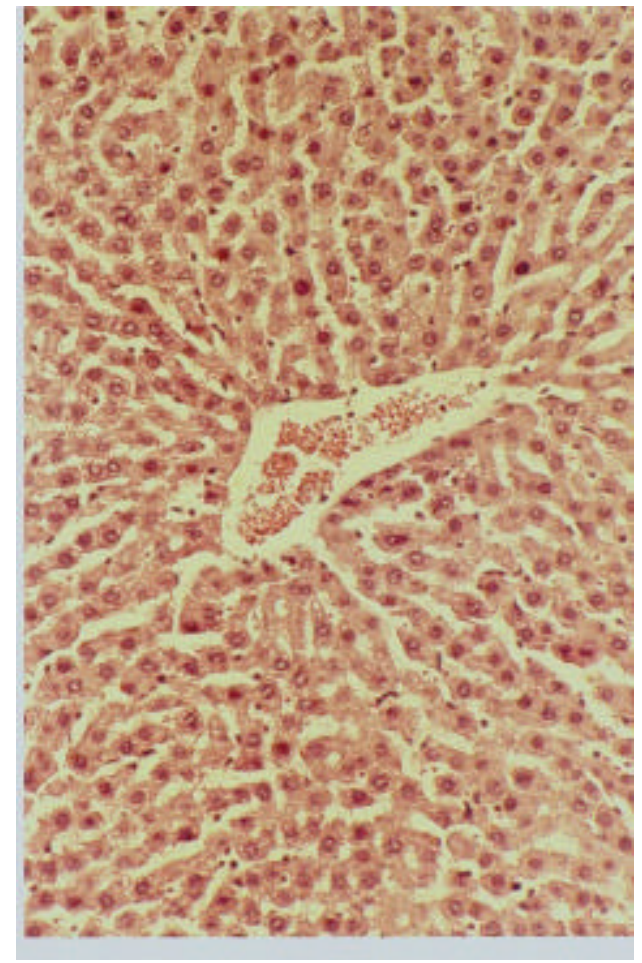

Figura 7 - Fotomicrografia do tecido hepático de rato que recebeu alimentação contaminada com 400 ? $\mathrm{g} \mathrm{kg}^{-1}$ de aflatoxinas $+1,0 \%$ de levedura da linhagem Y904 (aumento de 200 x).

Mais recentemente, Celik et al. (2003), verificaram que leveduras de panificação, não caracterizadas, vivas, também apresentavam potencial de reduzir aflatoxicoses em frangos, estando este trabalho de acordo com tais observações.

Analisando a Figura 8, a qual ilustra o tecido hepático de um animal que recebeu a dieta contaminada com aflatoxinas juntamente com a levedura Y904, acrescida de metionina e cisteina (T7), observa-se que os animais submetidos a este tratamento apresentaram-se com os fígados heptático muito bem preservado, com ausência de desorganização celular e sem a presença de necrose. Esta figura histológica revela-se bastante diferente daquela observada no tecido hepático de animais que receberam a dieta com aflatoxinas (T2) e, ao mesmo tempo, com características praticamente idênticas àquelas apresentadas pelo fígado de animais criados na ausência da toxina (T1), demonstrando que o T7 foi capaz de inibir a ocorrência de danos oriundos das aflatoxinas. 


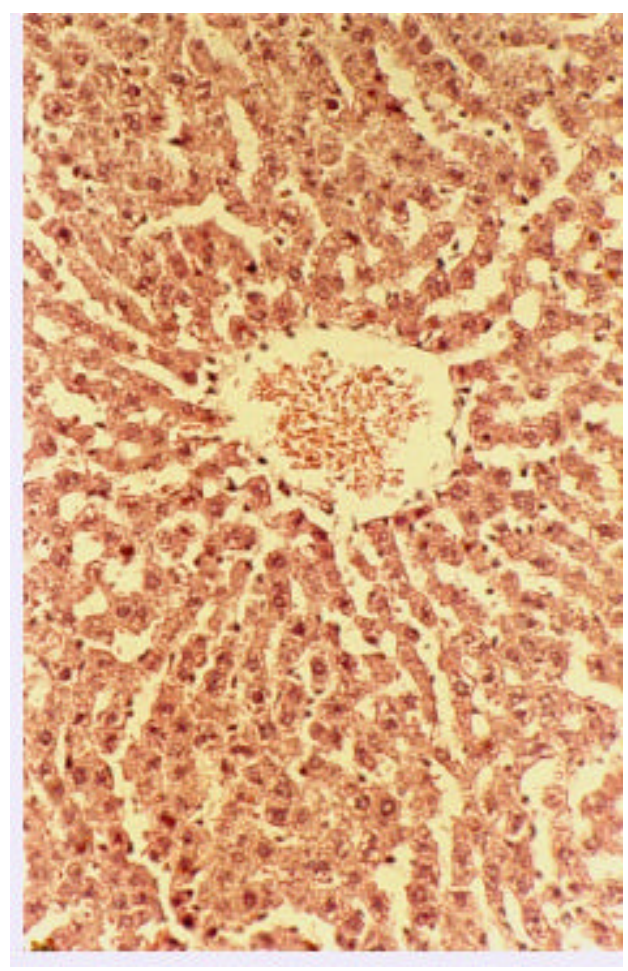

Figura 8 - Fotomicrografia do tecido hepático de rato que recebeu alimentação contaminada com 400 ? $\mathrm{g} \mathrm{kg}^{-1}$ de aflatoxinas + $1,0 \%$ de levedura da linhagem Y904, enriquecida com 1000 ppm de metionima + 1000 ppm de ciste ina (aumento de $200 \mathrm{x}$ ).

Isso indica que as leveduras da linhagem Y904, na concentração de 1\%, enriquecida com os aminoácidos metionína e cisteina, mostraram sua capacidade protetora contra aflatoxinas potencializadas. Estes resultados reforçam as afirmações de Smith \& Moss (1985), os quais relataram que a suplementação de aminoácidos apresenta potencial para aliviar prejuízos decorrentes da presença de aflatoxinas em alimentos.

Estas observações ressaltam a importância de novos estudos para aperfeiçoar o uso de leveduras enriquecidas em aminoácidos, a fim de se obter o melhor efeito sinérgico de leveduras associadas com tais compostos na prevenção de aflatoxicoses.

O mecanismo envolvido na capacidade de leveduras em prevenir os danos promovidos por aflatoxinas ainda é incerto e há várias hipóteses que tentam explicar tal habilidade. De acordo com Stanley et al. (1993); Parlat et al. (2001) e Raju \& Devegowda (2002), o mecanismo envolve a capacidade da levedura em seqüestrar a toxina. Um modelo similar a esse foi 
proposto por Yiannikouris et al. (2003), que através de ensaios "in vitro" concluíram que a habilidade de leveduras em reduzir efeitos de micotoxinas, relacionada com a capacidade de adsorver essas moléculas nas paredes celulares e com isso limitar a biodisponibilidade ao organismo.

Para Krause et al. (1989) e Crumplen et al. (1989), as leveduras podem fornecer enzimas, vitaminas ou outros fatores de crescimento não identificados, que reduzem os distúrbios promovidos pelas aflatoxinas. Os estudos conduzidos por Baptista et al. (2001) reforçaram essa última hipótese, uma vez que não foi observado, "in vivo", efeito protetor produzido por leveduras mortas e, nem tão pouco de componentes da parede celular de leveduras, recomendados com adsorventes, contra os danos observados por aflatoxinas em nível histológico.

Baptista et al., (2004) sugerem que, possivelmente, um complexo enzimático esteja envolvido na descontaminação de aflatoxinas pela ação de leveduras, uma vez que somente as leveduras vivas têm demonstrado tal habilidade. Nesse sentido, o complexo enzimático glutationa-s-transferase (GST), o qual as leveduras podem possuir com alta atividade (Alfafara et al., 1992), e é um dos responsáveis pela biotransformação de aflatoxinas no organismo animal e, além disso, auxilia na eliminação dessa toxina do organismo (Hayes et al., 1991), poderia estar envolvido com tal mecanismo de proteção.

\subsection{Conclusões}

As linhagens de levedura Y1026 e Y904 apresentaram habilidade de reduzir os danos promovidos por aflatoxinas;

Todas as concentrações de leveduras avaliadas apresentaram capacidade de minimizar aflatoxicoses. Contudo, considerando a eficiência técnica-econômica, as melhores doses de leveduras foram $0,5 \%$ e 1\%, para as linhagens Y1026 e Y904, respectivamente. 


\section{Diferentes doses de Saccharomyces cerevisiae da linhagem Y1026 no controle de aflatoxicoses}

\section{Resumo}

Aflatoxinas são metabólitos secundários produzidos por algumas espécies de fungos, que quando ingeridos podem causar danos à saúde de humanos e de animais. O objetivo deste trabalho foi avaliar o efeito de diferentes concentrações de Saccharomyces cerevisiae da linhagem Y1026 na redução dos danos induzidos pela ingestão de aflatoxinas. Foram elaboradas sete dietas, sendo uma dieta livre de aflatoxinas (T1) e seis dietas contaminadas com 550 ? g kg-1 de aflatoxinas, das quais uma a controle com aflatoxinas (T2) e cinco com a adição de leveduras vivas da linhagem Y1026, nas seguintes concentrações: 0,2\%; 0,5\%; 1,0\%; 2,0\% e 5,0\%. Um bioensaio com ratos Wistar, de 21 dias de idade e cerca de 60 gramas cada, foi conduzido durante 60 dias. Os animais foram distribuídos em delineamento inteiramente casualizado, com 4 repetições por tratamento. Os parâmetros para avaliação foram: consumo médio, ganho de peso médio, conversão alimentar, provas bioquímicas e tecido hepático. Os resultados demonstraram que o consumo médio de alimentos foi maior entre os animais que receberam dieta livre de aflatoxinas (T1) do que nos animais que receberam a dieta contaminada com aflatoxinas (T2); o ganho de peso, a conversão alimentar e o peso relativo dos órgãos internos foram semelhantes entre os animais submetidos ao T1 e ao T2. As provas bioquímicas demonstraram que as atividades da aspartato aminotransferase e da alanina aminotransferase foram maiores no tratamento $\mathrm{T} 1$ do que nos demais tratamentos e que a atividade da fosfatase alcalina foi semelhante nos animais submetidos aos tratamentos T1 e T2. Os exames histopatológicos revelaram que os animais do grupo controle com aflatoxinas apresentaram-se altamente afetados pelas aflatoxinas; os animais submetidos aos tratamentos com 0,2 ou $0,5 \%$ 
de leveduras apresentaram aspectos morfológicos semelhantes ao controle com aflatoxinas; os animais que receberam 1 e $2 \%$ de leveduras apresentaram sensível redução dos danos histológicos e os animais que receberam $5 \%$ de leveduras praticamente não apresentaram sintomas de aflatoxicoses em nível histológico. Conclui-se que, a concentração de levedura aplicada teve efeito determinante na eficácia deste microrganismo para 0 controle de aflatoxicoses e que do ponto de vista técnicoeconômico a dose de $2 \%$ de leveduras vivas foi a mais eficiente para minimizar os danos induzidos por aflatoxinas.

\section{Different levels of Saccharomyces cerevisiae (strain Y1026) to reduce aflatoxicosis}

\section{Summary}

Aflatoxins are secondary metabolites produced by some species of fungi, that when ingested can cause damages to the human and animal health. The aim of this work was to evaluate the ability of different levels of Saccharomyces cerevisiae of the strain Y1026 to reduce the damages induced by aflatoxins ingestion. An aflatoxin-free diet and six diets with 550 ?g kg-1 aflatoxins, which consited a control with aflatoxins and five had the yeast strain Y1026 (concentrations at $0.2 \% ; 0.5 \% ; 1.0 \% ; 2.0 \%$ and $5.0 \%$ ). The bioassay with 21-day-old $60-\mathrm{g}$ Wistar rats was conducted for 60 days. The animals were randomly distributed within the treated diets (treatments) with four repetitions for each treatment. Feed conversion, liver function indexes, feed intake, live weight gain and liver tissue parameters were evaluated. There were statistic differences between animals that were fed aflatoxin-free diet when compared to animals that were fed aflatoxin diet (T2); however, the feed conversion and weight gain were similar between the animals submitted to the treatments T1 and T2. The activity of the liver enzymes was higher for animals fed aflatoxin-free diet than for animals fed other diets. Histopathological study revealed that the animals fed diets with aflatoxins with and without 0.2 or $0.5 \%$ yeast cells showed clear signs of hepatotoxicity, while animals that were fed diets higher concentrations of yeast cells had great reduction in liver tissue damages. The level of the yeast cells (strain Y1026) used in the formulations was correlated with the reduction of aflatoxicosis for Wistar rats. 


\subsection{Introdução}

As aflatoxinas são metabólitos secundários produzidos por fungos em alimentos ou rações, as quais, quando ingeridas, podem resultar em doenças ou morte de animais, incluindo 0 ser humano (Hayes, 1981). As doenças causadas pela exposição às aflatoxinas são denominadas aflatoxicoses e podem ser crônicas ou agudas, dependendo da dose (Smith \& Moss, 1985).

As principais aflatoxinas produzidas pelos fungos são $B_{1}, B_{2}, G_{1}, e G_{2}$. Com relação aos efeitos tóxicos, as principais aflatoxinas apresentam os seguintes graus de toxicidade: $B_{1}>G_{1}>B_{2}$ $>\mathrm{G}_{2}$ (Carnaghan et al., 1963).

As aflatoxinas causam alteração no metabolismo de carboidratos e prejudicam 0 transporte de lipídios, resultando em diminuição das concentrações de glicose e acúmulo de lipídios dentro dos hepatócitos (Wogan, 1973; Rodricks \& Stoloff, 1977; Heathcote \& Hibbert, 1978; Naber \& Wallace, 1979). Além disso, as aflatoxinas afetam os metabolismos de proteínas e de ácidos nucléicos (Ellis et al., 1991).

A exposição a concentrações crônicas é mais provável do que às doses agudas e existem evidências que levam a crer que o consumo de concentrações crônicas de aflatoxinas conduza ao câncer. Assim, as exposições a concentrações crônicas destas toxinas representam sérios problemas para a saúde pública (Roebuch \& Maxuilenko, 1994).

Há múltiplos fatores envolvidos na avaliação dos impactos econômicos provenientes da contaminação de alimentos por aflatoxinas, considerando que a mesma possa ocorrer nas etapas de produção, colheita, transporte, armazenamento, processamento e distribuição dos alimentos. Além disso, os custos com perdas de vidas de humanos e de animais, associados com as perdas de produção, custos com o tratamento de enfermidades, custos com regulamentação e despesas com pesquisas. Esses fatores levaram muitos autores a estimar gastos anuais de vários milhões de dólares pela ocorrência de aflatoxinas em produtos alimentícios (Russel et al., 1991; Skrinjar et al., 1995; Hussein \& Brasel, 2001).

Em contrapartida, para neutralizar a severidade de dieta contendo aflatoxinas, o efeito de Saccharomyces cerevisiae tem sido reconhecido por diminuir o estresse em animais, ser fonte de 
vitaminas, conter um fator de crescimento não identificado, conter enzimas e proteína (Phillips \& Von Tungeln, 1984; Crumplen et al., 1989; Krause et al., 1989).

A utilização de leveduras vivas para o controle de aflatoxinas tem sido relatada pelo sucesso para tal finalidade. Estudos com diferentes espécies animais apontam a sua eficiência na redução dos danos das aflatoxinas através da avaliação de parâmetros macroscópicos como o ganho de peso e conversão alimentar, e microscópicos como provas bioquímicas e exames histopatológicos (Stanley et al., 1993; Parlat et al., 2001; Baptista et al., 2002).

O propósito desta pesquisa foi avaliar a habilidade de diferentes concentrações de Saccharomyces cerevisiae da linhagem Y1026 na redução dos danos induzidos pela ingestão de aflatoxinas.

\subsection{Material e métodos}

\subsubsection{Animais e tratamentos}

Ratos albinos (Rattus norvegicus), da linhagem Wistar, com 21 a 25 dias de idade e pesando aproximadamente 60 gramas cada, foram distribuídos em 28 gaiolas, separados em 7 grupos de tratamentos com 4 animais cada, para avaliar a interação de diferentes doses de S. cerevisiae da linhagem Y1026 sobre os efeitos prejudiciais de aflatoxinas em animais de laboratório. O delineamento experimental utilizado foi o inteiramente casualizado, consistindo de sete dietas, sendo uma o controle livre de aflatoxinas - em níveis não detectáveis (NND), ? 0,5 ? $\mathrm{g} \mathrm{kg}^{-1}$, e, seis dietas contaminadas com aflatoxinas na concentração de 550 ? $\mathrm{g} \mathrm{kg}^{-1}$; das quais 0 controle com aflatoxinas e as demais dietas suplementadas com leveduras, nas seguintes concentrações: 0,2\%; 0,5\%; 1,0\%; 2,0\% e 5,0\%.

Os animais foram alimentados durante 60 dias, com dieta à base de proteína, carboidratos, lipídios, fibras, mistura mineral e mistura vitamínica (dieta AIN-93G), conforme descrita por Reeves et al. (1993). A cada animal foram fornecidas 15 gramas de dieta e água "ad libitum" diariamente. A contaminação das dietas foi realizada pela adição de amendoim naturalmente contaminado por aflatoxinas. As leveduras foram aplicadas às dietas após a 
contaminação. Todas as dietas foram estocadas em câmara fria até seu fornecimento aos animais.

\subsubsection{Viabilidade de leveduras}

Foram utilizadas leveduras da espécie Saccharomyces cerevisiae da linhagem Y1026, aplicadas na forma desidratada viva. A viabilidade das células de leveduras foi determinada pelo método de coloração com azul de metileno (0,1\%), conforme descrito por Pierce (1970). As leveduras apresentavam uma viabilidade média de $58,3 \%$ no momento da instalação do experimento.

\subsubsection{Determinação de aflatoxinas}

A determinação de micotoxinas (aflatoxinas, zearalenona, ocratoxina A e deoxinivalenol) foi feita usando cromatografia de camada delgada, de acordo com as metodologias descritas por Soares \& Rodrigues-Amaya (1989) e Eppley et al (1986), com adaptações, como a quantificação feita através de cromatografia bi-direcional, onde o limite de detecção para as quatro aflatoxinas foi de 0,5 ? $\mathrm{g} \mathrm{kg}^{-1}$. Não foi detectada a presença de zearalenona, ocratoxina A e deoxinivalenol.

\subsubsection{Biometria dos órgãos internos e provas bioquímicas}

Aos 60 dias de ensaio, os animais foram anestesiados em câmara saturada com halotano. Em seguida, o sangue foi coletado e o soro sangüíneo obtido por centrifugação com $1200 \mathrm{~g}$ por minutos durante 20 minutos, em tubos pré-condicionados. As amostras de soro foram usadas para a realização das provas bioquímicas, das quais foram obtidas as atividades das seguintes enzimas: Aspartato aminotransferase (AST); Fosfatase alcalina (FA) e Alanina aminotransferase (ALT). A detecção das atividades específicas destas enzimas foi realizada utilizando um analisador automático Theinon RA-100 e os kits comerciais da BioSystems Reagents \& Instruments Co, específicos para cada enzima. 
Também foram extraídos e pesados os órgãos internos (fígado, rins e coração) e o peso relativo de stes órgãos por $100 \mathrm{~g}$ de peso vivo foi encontrado multiplicando-se o peso do total do órgão por 100 e, dividindo -se o valor obtido pelo peso vivo do animal. Além disso, fragmentos dos fígados foram fixados em solução de formol 10\% e utilizados para o estudo histológico.

\subsubsection{Estudo histopatológico}

A partir de cada uma das peças de tecido hepático dos 28 animais, foram preparadas três lâminas histológicas, conforme os procedimentos descritos por Pacheco (1981) e foram coradas com hematoxilina e eosina $(\mathrm{HE})$. Após o preparo, o estudo histopatológico das lâminas foi realizado ao microscópio de luz, em aumento de 16 × 1,25 x 10 (200x).

O tecido hepático de animais que receberam dieta livre de aflatoxinas foi adotado como padrão de referência para isento de hepatotoxidez.

\subsubsection{Estatística}

Os resultados foram analisados pelo programa SAS (Herzberg, 1990) para a determinação da análise de variância e a comparação entre médias foi realizada usando-se 0 teste de Tukey com um nível de confiança de 95\%.

\subsection{Resultados e discussão}

\subsubsection{Parâmetros para avaliação do aproveitamento do alimento}

A Tabela 3 mostra que os animais que receberam a dieta do tratamento T1 apresentaram consumo diário médio $(C D M)$ de alimentos maiores $(P<0,05)$ do que os animais que receberam a dieta do tratamento T2. Entretanto, não apresentaram (DM maiores do que os animais submetidos aos demais tratamentos. Estes resultados podem indicar que o consumo de 
alimentos contaminados com aflatoxinas tenha induzido a uma leve anorexia resses animais, estando os resultados de acordo com as observações citadas por Ellis et al. (1991) que relataram que em animais, um dos sintomas da ingestão de aflatoxinas é a anorexia.

Em relação ao ganho de peso médio (GPM), verifica-se que não ocorreram diferenças estatísticas $(P<0,05)$ de GPM entre os animais submetidos ao tratamento T1 quando comparados aos os animais submetidos aos tratamentos T2, T3, T4, T6. Entretanto, foram observadas maiores médias de GPM nos animais do grupo T1 do que nos animais submetidos aos tratamentos T5 e T7 (Tabela 3). Estes resultados podem indicar que a presença de aflatoxinas nas dietas não promoveu alteração de GPM, uma vez que não foram observadas diferenças estatísticas entre as médias desse parâmetro entre os animais submetidos ao T1 e ao T2. Assim, as diferenças observadas em outros tratamentos não podem ser atribuídas aos possíveis danos proporcionados por aflatoxinas. Estes resultados não corroboram com aqueles relatados por Edds \& Bortel (1983), os quais citaram que a ingestão de aflatoxinas pelos animais pode promover a diminuição de ganho de peso. Uma hipótese que poderia explicar o ocorrido é que os animais de todos os grupos sofreram bastante oscilação de ganho de peso durante a fase final da investigação, devido ao estresse ambiental.

Em relação à conversão alimentar (CVA), foi observado que as médias de conversão dos animais submetidos aos tratamentos T1, T2, T3, T4 e T6 não apresentaram diferenças estatísticas (Tabela 3). Entretanto, o tratamento T1 apresentou médias de CVA menores dos que aquelas obtidas pelos animais submetidas aos tratamentos T5 e T7. Estes resultados indicam que a ingestão de aflatoxinas nos animais submetidos ao diferentes tratamentos não interferiu na conversão alimentar dos mesmos, uma vez que os resultados de conversão alimentar dos animais dos grupos controles, T1 e T2, foram semelhantes entre si. Assim, as diferenças encontradas na conversão alimentar dos animais dos grupos T5 e T7 não podem ser atribuídas à exposição às aflatoxinas.

Os pesos relativos dos órgãos internos (fígado, coração e rins), dos animais submetidos aos diferentes tratamentos, não diferiram estatisticamente $(P<0,05)$ (Tabela 3). Os efeitos do nível de contaminação utilizado e do tempo de exposição às estas toxinas pelos animais não foram suficientes para provocar diferenças significativas, no peso relativo destes órgãos nos 
indivíduos avaliados. Estes resultados podem ser explicados pelo fato de ratos serem animais resistentes aos efeitos das aflatoxinas (Barnes \& Butler, 1964).

Tabela 3 - parâmetros de avaliação dos alimentos e peso relativo de órgãos internos

\begin{tabular}{|c|c|c|c|c|c|c|}
\hline \multirow[b]{2}{*}{ Tratamentos } & \multirow{2}{*}{$\begin{array}{l}\text { Consumo } \\
\text { médio de } \\
\text { Alimento } \\
\text { (g/dia) }\end{array}$} & \multirow{2}{*}{$\begin{array}{c}\text { Ganho de } \\
\text { peso } \\
\text { Médio } \\
\text { (g/dia) }\end{array}$} & \multirow[t]{2}{*}{$\begin{array}{l}\text { Conversão } \\
\text { Alimentar }\end{array}$} & \multicolumn{3}{|c|}{$\begin{array}{l}\text { Peso relativo por } 100 \\
\text { gramas de peso vivo }\end{array}$} \\
\hline & & & & $\begin{array}{l}\text { Fígado } \\
\text { (g) }\end{array}$ & $\begin{array}{l}\text { Rins } \\
(\mathrm{g})\end{array}$ & $\begin{array}{c}\text { Coração } \\
\text { (g) }\end{array}$ \\
\hline Dieta livre de afaltoxinas (T1) & $15,00 \mathrm{a}$ & $3,34 \mathrm{a}$ & $4,55 \mathrm{~b}$ & $8,27 \mathrm{a}$ & $2,52 \mathrm{a}$ & $1,26 \mathrm{a}$ \\
\hline Dieta padrão com 550 ?g kg-1 de aflatoxinas (T2) & $13,49 \mathrm{~b}$ & $3,11 a b$ & $4,37 \mathrm{~b}$ & $9,47 \mathrm{a}$ & $2,26 \mathrm{a}$ & $1,07 \mathrm{ab}$ \\
\hline $\mathrm{T} 2+0,2 \%$ da levedura Y1026 (T3) & $14,12 a b$ & $2,86 a b$ & $4,97 \mathrm{ab}$ & $9,10 \mathrm{a}$ & $2,08 \mathrm{a}$ & $1,03 a b$ \\
\hline $\mathrm{T} 2+0,5 \%$ da levedura Y1026 (T4) & $14,50 a b$ & $3,20 \mathrm{a}$ & $4,53 \mathrm{~b}$ & $9,20 \mathrm{a}$ & $2,21 \mathrm{a}$ & $1,01 \mathrm{ab}$ \\
\hline T2 + 1,0\% da levedura Y1026 (T5) & $14,19 a b$ & $2,51 b$ & $5,75 \mathrm{a}$ & 7,98 a & $2,07 \mathrm{a}$ & $0,90 \mathrm{ab}$ \\
\hline T2 + 2,0\% da levedura Y1026 (T6) & $14,82 \mathrm{ab}$ & $2,92 a b$ & $5,08 a b$ & $8,57 \mathrm{a}$ & $2,19 \mathrm{a}$ & $1,04 a b$ \\
\hline $\mathrm{T} 2+5,0 \%$ da levedura Y1026 (T7) & $14,33 a b$ & $2,51 \mathrm{~b}$ & $5,77 \mathrm{a}$ & $7,77 \mathrm{a}$ & $2,03 \mathrm{a}$ & $0,80 \mathrm{~b}$ \\
\hline CV (\%) & 4,53 & 10,22 & 9,92 & 11,86 & 11,45 & 18,49 \\
\hline
\end{tabular}

Médias seguidas com a mesma letra, nas colunas, não diferem estatisticamente entre si em nível de significância de $5 \%$ através do teste de Tukey.

\subsubsection{Provas bioquímicas}

Nas provas bioquímicas foi observado que os animais submetidos aos diferentes tratamentos apresentaram diferenças estatísticas $(P<0,05)$ entre si para as médias de atividades das enzimas aspartato aminotransferase (AST) e alanina aminotransferase (ALT), sendo que as maiores médias foram observadas no tratamento T1 quando em comparação com as médias dos demais tratamentos e, outros tratamentos com exceção do T1, não apresentaram diferenças significativas $(P<0,05)$ entre eles (Tabela 4). A atividade da fosfatase alcalina $(F A)$ foi semelhante $(P<0,05)$ entre os animais dos tratamentos T1, T2 e T3. Entranto, as médias de atividade desta enzima nos animais que receberam o tratamento T1 foram superiores $(P<0,05)$ àquelas encontradas nos animais dos demais tratamentos (T4, T5, T6 e T7).

A literatura relata resultados contraditórios em relação aos efeitos das aflatoxinas sobre a atividade destas enzimas. Gawai et al. (1992) e Pozzi (2000), relataram o aumento da atividade das enzimas AST e ALT em ratos que receberam 1,5 $\mathrm{mg}$ de aflatoxinas por quilograma de peso corporal. Por outro lado, Stanley et al. (1993) observaram animais que receberam dietas 
contendo $5 \mathrm{mg} \mathrm{kg}^{-1}$ de aflatoxinas apresentaram redução na atividade das enzimas ALT, AST e lactato desidrogenase.

Tabela 4 - Parâmetros bioquímicos séricos dos ratos submetidos aos diferentes tratamentos.

\begin{tabular}{lccc}
\hline \multicolumn{1}{c}{ Tratamentos } & AST & ALT & FA \\
& $(\mathrm{u} / \mathrm{L})$ & $(\mathrm{u} / \mathrm{L})$ & $(\mathrm{u} / \mathrm{L})$ \\
\hline Dieta livre de afaltoxinas (T1) & $210.37 \mathrm{a}$ & $285.93 \mathrm{a}$ & $243.77 \mathrm{a}$ \\
Dieta padrão com 550 (g kg-1 de aflatoxinas (T2) & $82.32 \mathrm{~b}$ & $57.57 \mathrm{~b}$ & $147.54 \mathrm{ab}$ \\
T2 + 0,2\% da levedura Y1026 (T3) & $70.53 \mathrm{~b}$ & $54.58 \mathrm{~b}$ & $180.8 \mathrm{ab}$ \\
$\mathrm{T} 2+0,5 \%$ da levedura Y1026 (T4) & $100.80 \mathrm{~b}$ & $40,43 \mathrm{~b}$ & $117.53 \mathrm{~b}$ \\
T2 + 1,0\% da levedura Y1026 (T5) & $70.98 \mathrm{~b}$ & $51.30 \mathrm{~b}$ & $125.08 \mathrm{~b}$ \\
T2 + 2,0\% da levedura Y1026 (T6) & $93.30 \mathrm{~b}$ & $52.80 \mathrm{~b}$ & $137.57 \mathrm{~b}$ \\
T2 + 5,0\% da levedura Y1026 (T7) & $86.50 \mathrm{~b}$ & $31.90 \mathrm{~b}$ & $83.35 \mathrm{~b}$ \\
CV (\%) & $\mathbf{3 2 , 2 7}$ & $\mathbf{6 3 , 3 7}$ & $\mathbf{2 8 , 8 8}$ \\
\hline
\end{tabular}

Médias seguidas com a mesma letra, nas colunas, não diferem estatisticamente entre si ao nível de significância de $5 \%$ através do teste de Tukey.

\subsubsection{Diagnóstico histopatológico}

As análises histopatológicas foram realizadas com exame de 12 lâminas disponíveis para cada tratamento e em cada tratamento foi selecionada uma fotomicrografia que representasse esse conjunto. Desse modo, a seguir serão ilustrados, apresentados e discutidos os resultados obtidos no estudo histopatológico dos animais de cada tratamento.

A Figura 9 mostra o tecido hepático de um animal que foi submetido ao tratamento T1, no qual pode-se observar uma organização celular normal, sem a presença de degeneração e sem necrose celular, além das células em degeneração fisiológica. Os resultados obtidos estão de acordo com o previsto, uma vez que os animais deste grupo receberam uma dieta sem a presença de aflatoxinas. Assim, o tecido hepático de animais do T1 foi adotado como padrão de referência para investigar se os animais submetidos aos demais tratamentos sofreram ou não os danos induzidos pela ingestão das aflatoxinas e se os tratamentos com leveduras foram capazes ou não de diminuir os danos de tais toxinas. 


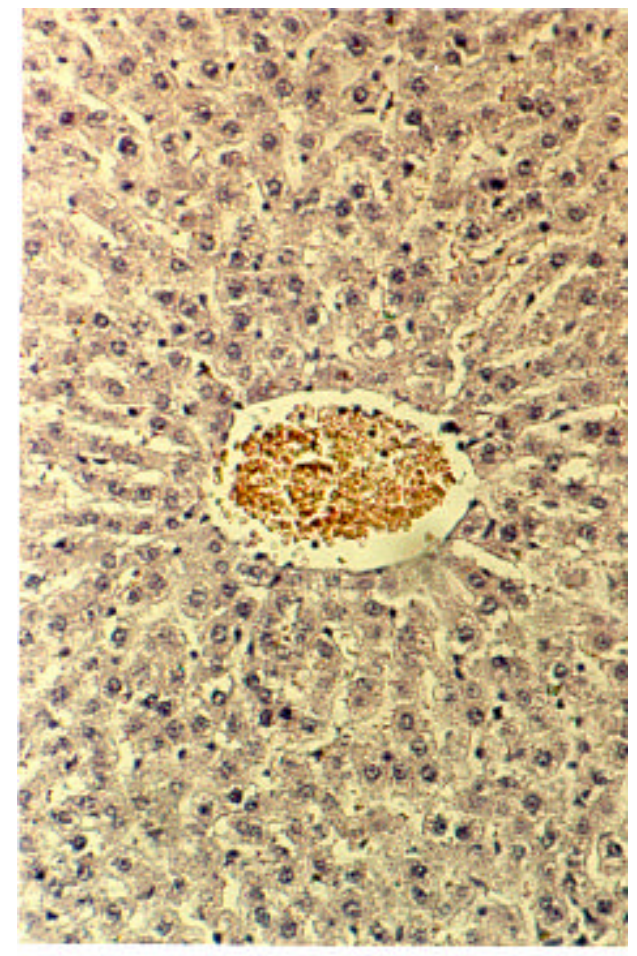

Figura 9 - Fotomicrografia do tecido hepático de rato que recebeu alimentação livre de aflatoxinas (aumento de 200x).

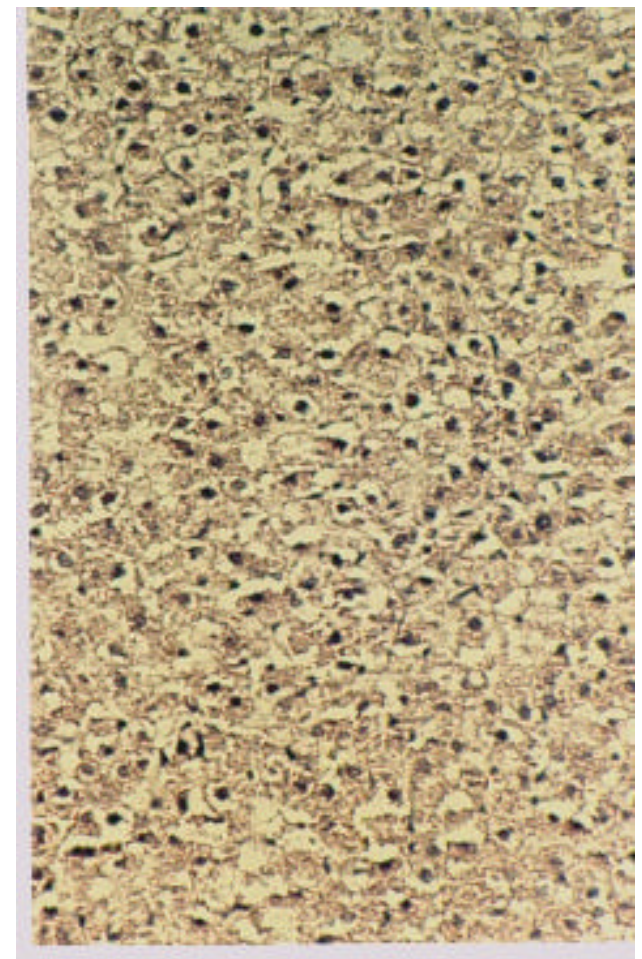

Figura 10 - Fotomicrografia do tecido hepático de rato que recebeu alimentação contaminada com $550 ? \mathrm{~g} \mathrm{~kg}^{-1}$ de aflatoxinas (aumento de $200 x)$.

A Figura 10 apresenta o aspecto do tecido hepático de animais que foram submetidos ao tratamento T2, através da qual pode-se observar a presença de grande desorganização hepática, praticamente todas as células foram afetadas e há a presença de um grande número de células necrosadas pela degeneração hidrópica severa. Os resultados obtidos estão acordo com aqueles descritos por outros autores (Newberne \& Butler, 1969; Wogan, 1973; Rodricks \& Stoloff, 1977; Heathcote \& Hibbert, 1978; Naber \& Wallace, 1979), os quais relataram desorganização do tecido hepático, com proliferação de ductos biliares e necrose do parênquima hepático, como algumas das manifestações de danos induzidos pela ingestão de aflatoxinas. Isso significa que a dose ministrada e o tempo de exposição foram suficientes para promover danos a nível histológico.

As Figuras 11 e 12 mostram tecidos hepáticos de animais submetidos aos tratamentos T3 e T4, respectivamente. Através destas figuras nota-se a presença de muitas células necrosadas, com presença de edema celular, degeneração gordurosa e grande desorganização celular. Os 
aspectos morfológicos apresentados são semelhantes ao encontrado nos animais submetidos ao tratamento T2. Portanto, nas condições que foi conduzido este estudo, os tratamentos com a adição de 0,2\% e 0,5\% de leveduras vivas da linhagem Y1026 não foram capazes de inibir os efeitos tóxicos da aflatoxinas.

Estes resultados não estão de acordo com aqueles obtidos por Baptista et al. (2001), os quais verificaram que leveduras vivas eram capazes de reduzir os efeitos tóxicos das aflatoxinas. As possíveis explicações para o ocorrido são: na investigação conduzida por aqueles autores a dose de leveduras aplicada foi maior do que as utilizadas nestes tratamentos; o nível de contaminação foi menor e o tempo de exposição dos animais às aflatoxinas também foi menor.

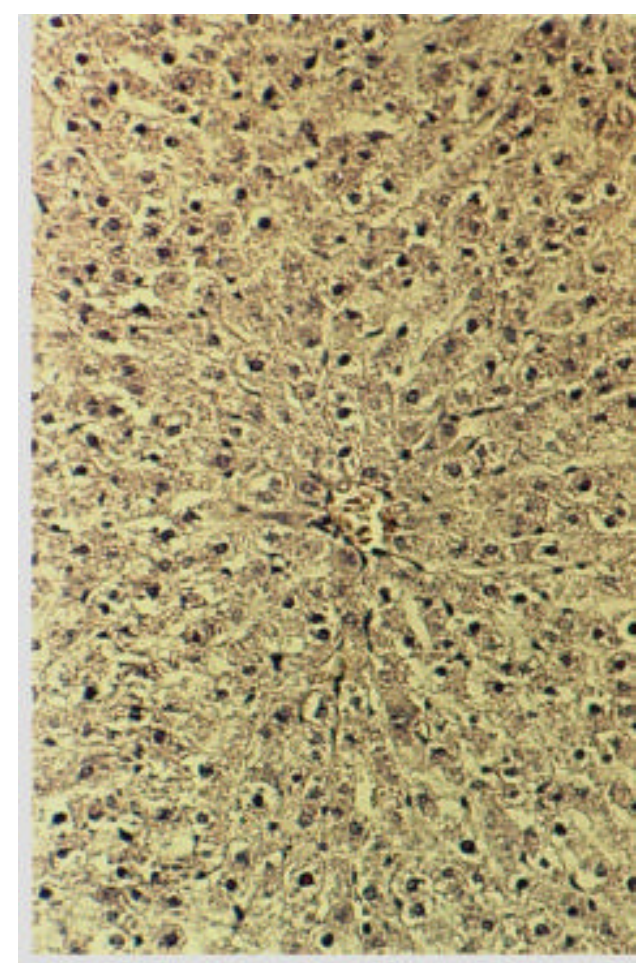

Figura 11 - Fotomicrografia do tecido hepático de rato que recebeu alimentação contaminada com 550 ?g kg-1 de aflatoxinas + $0,2 \%$ de levedura da linhagem Y1026 (aumento de 200x)

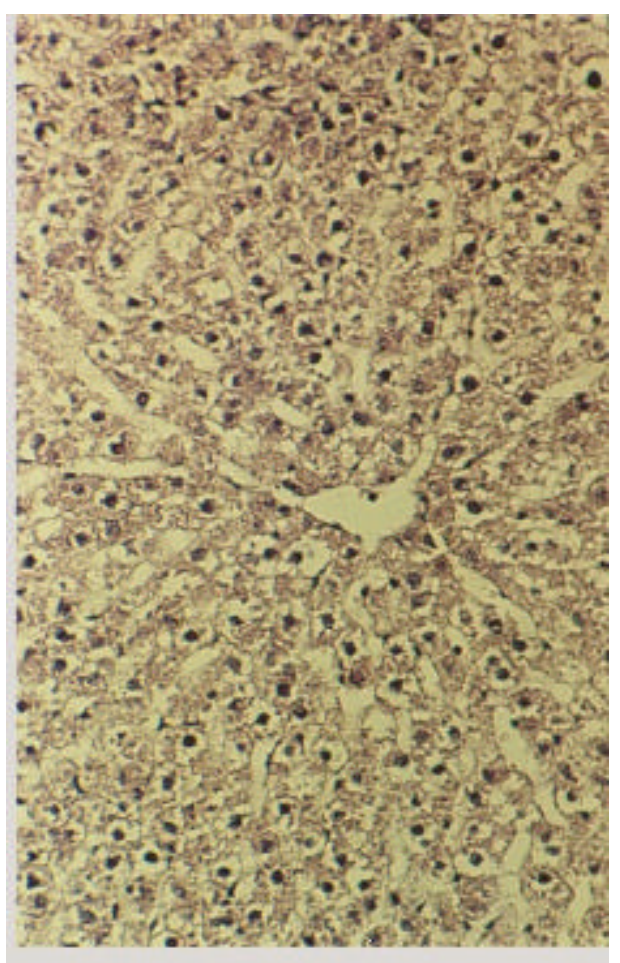

Figura 12 - Fotomicrografia do tecido hepático de rato que recebeu alimentação contaminada com 550 ? g kg-1 de aflatoxinas $+0,5 \%$ de levedura da linhagem Y1026 (aumento de 200x)

Na Figura 13, pode-se observar o tecido hepático de um animal que recebeu a dieta do tratamento $T 5$, no qual verificase a presença de poucas alterações celulares, com pequeno grau de desorganização celular, apresentando sinais leves de toxicidade. Estes resultados indicam 
que a dose de $1 \%$ de leveduras vivas foi capaz de reduzir os efeitos de aflatoxinas, mas permitiu a ocorrência de algumas poucas alterações celulares, o que pode ser indício que esta, embora se consiga reduzir os danos induzidos pelas aflatoxinas, não é a dose mais eficaz para a inibição de aflatoxicoses.

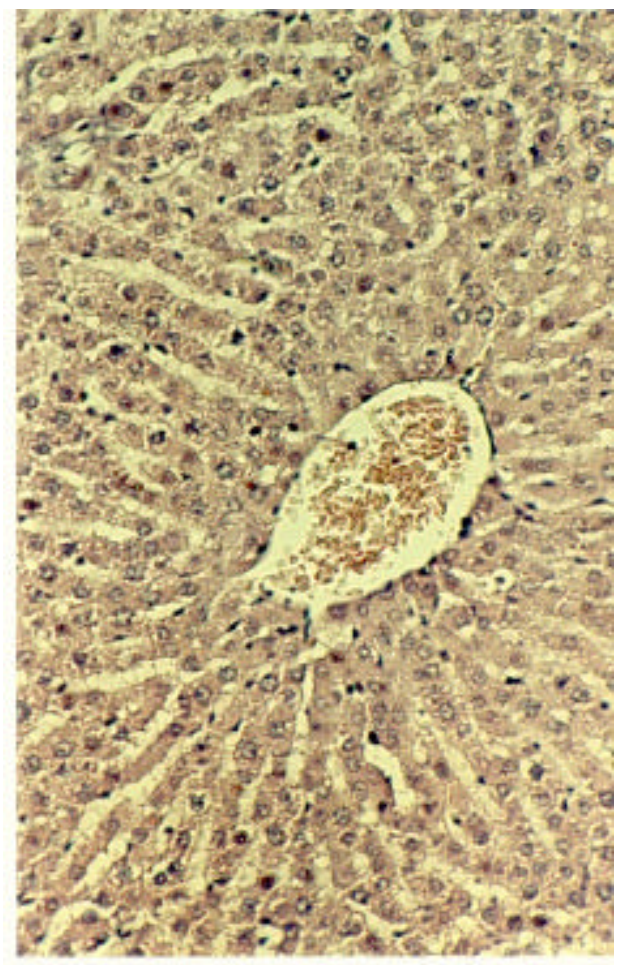

Figura 13 - Fotomicrografia do tecido hepático de rato que recebeu alimentação contaminada com 550 ? $\mathrm{g} \mathrm{kg}^{-1}$ de aflatoxinas + $1,0 \%$ de levedura da linhagem Y1026 (aumento de 200x)

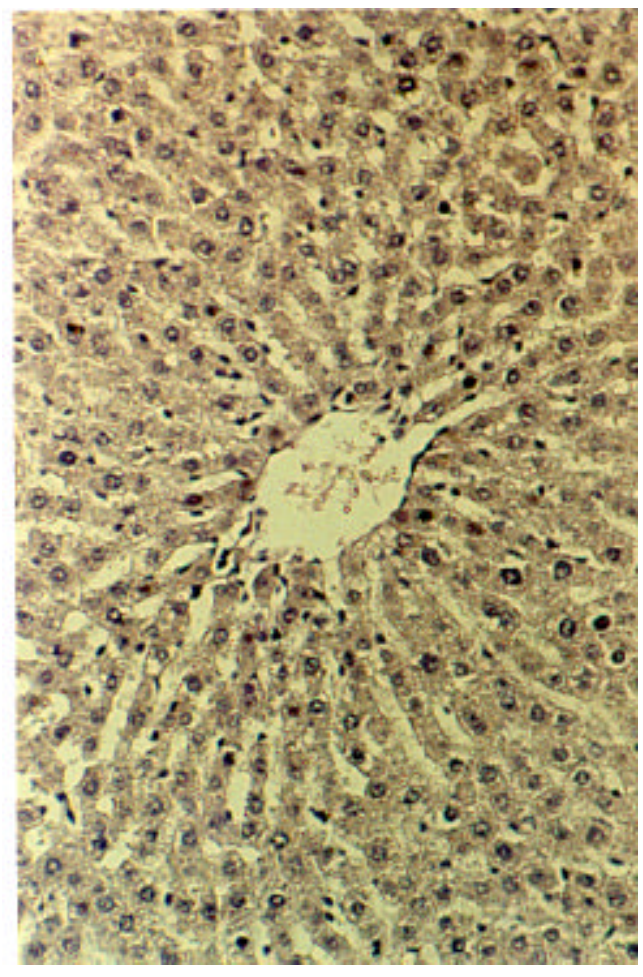

Figura 14 - Fotomicrografia do tecido hepático de rato que recebeu alimentação contaminada com 550 ?g kg-1 de aflatoxinas + $2,0 \%$ de levedura da linhagem Y1026 (aumento de 200x).

A Figura 14 ilustra o tecido hepático de um animal que foi submetido ao tratamento T6, através do qual verifica-se a presença de poucas alterações celulares, com um pequeno grau de desorganização celular, apresentando sinais de toxicidade menores do que os dos animais submetidos ao tratamento T2. Estes resultados demonstram uma tendência de redução dos danos histológicos induzidos pela ingestão de aflatoxinas à medida que se aumenta a dose de leveduras vivas. A literatura não relata a aplicação de leveduras vivas na concentração utilizada, 
contudo por analogia com outros estudos (Stanley et al., 1993; Parlat et al., 2001), pode-se dizer que os resultados obtidos foram semelhantes aos encontrados por estes autores.

O tecido hepático de animais submetidos ao tratamento $T 7$ apresenta sinais leves de toxicidade, quase com ausência de alterações celulares, podendo-se dizer que está muito semelhante aos tecidos hepáticos dos animais que não receberam aflatoxinas (T1) (Figura 15). Isso indica que a dose de $5 \%$ de leveduras vivas foi a mais eficaz para o controle de aflatoxicoses e que, praticamente, neutralizou os danos promovidos pelas aflatoxinas.

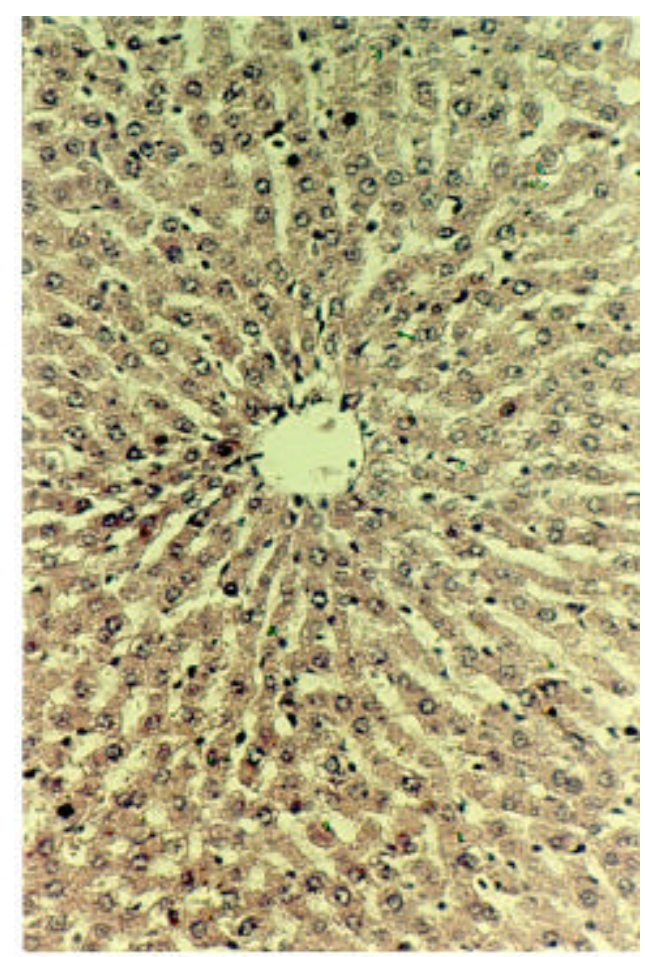

Figura 15 - Fotomicrografia do tecido hepático de rato que recebeu alimentação contaminada com 550 ? $\mathrm{g} \mathrm{kg}^{-1}$ de aflatoxinas + $5,0 \%$ de levedura da linhagem Y1026 (aumento de 200x).

A concentração de leveduras utilizadas no tratamento $\mathrm{T7}$ para o controle de aflatoxicose não apresenta menção na literatura. Contudo, por analogia pode-se dizer que os resultados obtidos corroboram que aqueles encontrados em outras pesquisas (Stanley et al., 1993; Parlat et al., 2001; Baptista et al., 2002). 


\subsection{Conclusões}

A concentração de levedura aplicada te ve efeito determinante na eficácia de leveduras para o controle de aflatoxicoses;

Considerando aspectos técnicos e econômicos, a dose de 2\% da levedura Y1026, viva, foi a mais eficiente para minimizar os danos induzidos por aflatoxinas 


\section{Absorção, distribuição e excreção de aflatoxina radiomarcada $\left(\mathrm{AFB}_{1}{ }^{3} \mathrm{H}\right)$ em ratos}

\section{Resumo}

Os objetivos deste trabalho foram avaliar os efeitos de diferentes linhagens de leveduras forncecidas em dietas sobre aflatoxicoses e de verificar a absorção, a distribuição e a excreção da radioatividade de AFB marcadda com o radiotraçador trítio $\left(\mathrm{AFB}_{1}{ }^{3} \mathrm{H}\right)$ em ratos Wistar. Um bioensaio com 30 ratos, distribuídos em gaiolas individuais inteiram ente ao acaso, foi conduzido por 28 dias. Os animais foram divididos em quatro grupos (tratamentos) e receberam as seguintes dietas: uma livre de aflatoxinas como controle negativo e três dietas contaminadas com 500 ? $\mathrm{g} \mathrm{kg}^{-1}$ de aflatoxinas, sendo uma como controle (positivo) com aflatoxinas e as outras duas suplementadas com 1\% das leveduras Y1026 ou Y904, respectivamente. No $18^{\circ}$ dia do ensaio, seis animais de cada grupo que recebia dieta contaminada com aflatoxinas foram transferidos para gaiolas metabólic as, onde permaneceram em adaptação por cinco dias e, no $23^{\circ}$ dia de ensaio, estes receberam, por via oral, uma dose simples de 2 ? Ci/animal de $\mathrm{AFB}_{1}{ }^{3} \mathrm{H}$. A absorção, a distribuição e a excreção da radioatividade foram avaliadas durante $120 \mathrm{~h}$. Os três animais restantes de cada um dos tratamentos foram mantidos nas condições iniciais e no $28^{\circ}$ dia foram sacrificados e seus fígados foram submetidos às análises histopatológicas. O radioensaio demonstrou que a absorção, a distribuição e a eliminação da radioatividade de $\mathrm{AFB}_{1}{ }^{3} \mathrm{H}$ ocorreram em tempos maiores nos animais que receberam dietas contaminadas e suplementadas com as leveduras. Por outro lado, os exames histopatológicos revelaram que os animais submetidos ao controle com aflatoxinas apresentaram sinais evidentes de hepatotoxidez e que os animais que receberam a toxina juntamente com as leveduras apresentaram poucos danos nos tecidos hepáticos. Conclui-se que as leveduras Y1026 e Y904 apresentaram capacidade de reduzir as aflatoxicoses e que modificaram a absorção, a distribuição e a eliminação da radioatividade de $\mathrm{AFB}_{1} 3 \mathrm{H}$ em ratos Wistar. 


\section{Absorption, distribution and excretion of tritium-labeled $B_{1}$ aflatoxin $\left(\mathrm{AFB}_{1}{ }^{3} \mathrm{H}\right)$ in rats}

\section{Summary}

The objectives of this study were to evaluate the effects of yeast cells on aflatoxicosis and to observe the absorption, distribution and excretion of tritium-labeled $\mathrm{B}_{1}$ aflatoxin $\left(\mathrm{AFB}_{1}{ }^{3} \mathrm{H}\right)$ in Wistar rats. Thirty Wistar rats placed randomly in individual cages for 28 days were used in this bioassay. The animals were divided into four groups and each was fed one of the following formulations (Treatments 1 to 4): an aflatoxin-free diet (T1) and three aflatoxin-contaminated diets (500 ? g kg1), which were without yeast (T2) and in the presence of 1\% dehydrated active yeast strain Y1026 (T3) and strain Y904 (T4). On the $18^{\text {th }}$ day of the bioassay, six animals from each group were transferred to metabolic cages, where the animals were kept for five days for adaptation and, on the $23^{\text {th }}$ day each animal received a single oral dose of $\mathrm{AFB}_{1}{ }^{3 \mathrm{H}}$ at 2 ? Ci/animal. Parameters of absorption, distribution and excretion of the $\mathrm{AFB}_{1}{ }^{3} \mathrm{H}$ were evaluated for $120 \mathrm{~h}$. Three animals from each treatment were kept at the initial conditions and their liver tissues were analyzed after the $28^{\text {th }}$ day. Radioassay showed that the absorption, distribution and excretion of the $\mathrm{AFB}_{1}{ }^{3} \mathrm{H}$ in animals fed T3 and T4 treatments were slower. Moreover, histopathological analysis revealed that animals from the $\mathrm{T} 2$ treatment had clear signs of hepatoxicity when compared to those from treatments T3 and T4, which had less liver damage. Therefore, these results suggest that yeast cells have he ability to effectively reduce tissue damage caused by aflatoxin and modify the absorption, distribution and elimination of $\mathrm{AFB}_{1}{ }^{3} \mathrm{H}$ in Wistar rats.

\subsection{Introdução}

As leveduras são os microrganismos, quantitativamente e economicamente, mais aproveitados pela humanidade. Devido ao conhecimento sobre a sua fisiologia, bioquímica e genética, apresenta várias aplicações industriais, tais como na elaboração de pães, vinhos, cervejas e 0 etanol entre outros. Além disso, mais recentemente o seu aproveitamento tem se expandido para a produção de aromas e aminoácidos (Beudeker, 1990; Benitez et al., 1996). 
No Brasil, a aplicação de leveduras é bastante expressiva em panificação, produção de bebidas e fabricação de etanol. Em muitos destes processos, após sua utilização primária, como agente de transformação, a biomassa gerada representa um subproduto que pode ser utilizada para diversas finalidades. Somente a indústria brasileira de etanol gera, anualmente, um excedente de 280 mil toneladas de leveduras de sangria (Butolo, 1997). Conseqüentemente, vislumbra-se uma necessidade real de se buscar novas aplicações para este importante agente biológico.

Dentre as diversas formas de se aproveitar as leveduras obtidas das indústrias mencionadas acima, a sua utilização na supressão dos efeitos prejudiciais de aflatoxina têm apresentado resultados satisfatórios (Stanley et al., 1993; Mahesh \& Devegowda, 1996; Parlat et al., 2001; Celik et al., 2003; Baptista et al., 2004).

As aflatoxinas, por sua vez, são moléculas altamente tóxicas produzidas pelos fungos Aspergillus flavus e Aspergillus parasiticus, que sob condições favoráveis de temperatura e umidade, crescem em certos alimentos (Heathcote, 1984).

No mundo todo, há uma crescente conscientização das sérias conseqüências que a ingestão de elevadas quantidades de aflatoxinas e, mesmo o consumo continuado de baixas concentrações, podem causar à saúde humana e animal (FAO, 1993).

Os efeitos das aflatoxinas no organismo podem afetar várias rotas metabólicas, promovendo alterações nos metabolismos de energia, carboidratos, lipídios, proteínas e sínteses de RNA e de DNA. Com o decorrer da exposição, estes efeitos são obs ervados em animais através de anorexia, diminuição do ganho de peso, diminuição da utilização do alimento ingerido, hemorragia e susceptibilidade ao meio ambiente, além do estresse por microrganismo (Edds \& Bortel, 1983; Smith \& Moss, 1985).

O impacto econômico resultante da contaminação por aflatoxinas ocorre em todas as etapas da produção vegetal e animal, comercialização e utilização de produtos (Kubena et al., 1990). A facilidade e a freqüência com que as aflatoxinas contaminam os produtos agrícolas e ao mesmo tempo, a exposição de animais a níveis crônicos destes compostos químicos, via dieta contaminada, podem ser as principais diferenças entre o lucro e o prejuízo para a atividade agroindustrial (Hamilton, 1984). 
A informação do modo de ação da leve dura sobre as aflatoxinas seria importante para aperfeiçoar estratégias que visem atuar no metabolismo desta toxina de modo a reduzir os prejuízos por ela promovidos. Para o estudo do metabolismo desta molécula, o uso de radiotraçadores tem sido empregado com sucesso (Wogan et al., 1967; Helferich et al., 1986; Kumagai at al., 1998; Ellis et al., 2000; Cupid et al., 2004).

Os objetivos deste trabalho foram avaliar os efeitos de leveduras sobre aflatoxicoses e de verificar a absorção, a distribuição e a excreção da radioatividade de aflatoxina marcada com trítio $\left(\mathrm{AFB}_{1}{ }^{3 \mathrm{H}}\right)$ em ratos Wistar.

\subsection{Material e métodos}

\subsubsection{Animais e tratamentos}

Ratos albinos (Rattus norvegicus), da linhagem Wistar, com 21 a 25 dias de idade, pesando aproximadamente 60 gramas cada, foram distribuídos em 30 gaiolas e separados em quatro grupos de tratamentos com três animais no controle sem aflatoxinas e nove animais nos demais tratamentos. O delineamento experimental utilizado foi o inteiramente casualizado, consistindo de quatro dietas, entre as quais: o controle sem aflatoxinas (T1) - dieta livre de aflatoxinas - em níveis não detectáveis (NND), ? 0,5 ?g kg-1; e, três dietas contaminadas com 500 ? $\mathrm{g} \mathrm{kg}^{-1}$ de aflatoxinas; das quais, o controle com aflatoxinas (T2) e as demais suplementadas com leveduras, a saber: dieta com 1,0\% de levedura Y1026 (T3) e dieta contendo 1,0\% de levedura Y904 (T4).

Os animais foram alimentados com dieta à base de proteína, carboidratos, lipídios, fibras, mistura mineral e mistura vitamínica (dieta AIN-93G), descrita por Reeves et al. (1993), durante 28 dias, com o fornecimento de água "ad libitum" e 15 gramas de dieta a cada animal, diariamente. A contaminação das dietas foi realizada pela adição de farelo de arroz contendo aflatoxinas naturais. As leveduras foram aplicadas às dietas após a contaminação. Todas as dietas foram estocadas em câmara fria até o seu fornecimento aos animais. 


\subsubsection{Viabilidade de leveduras}

A viabilidade das células das leveduras foi determinada pelo método de coloração com azul de metileno (0,1\%), conforme descrito por Pierce (1970). As leveduras apresentaram viabilidades médias de 36,51\%, 2 × $10^{8}$ UFC mL-1 (Y1026) e de 92,60\%, 6,5 x $10^{10} \mathrm{UFC} \mathrm{mL}^{-1}$ (Y904), no momento da instalação do experimento.

\subsubsection{Determinação de aflatoxinas}

A determinação de micotoxinas (aflatoxinas, zearalenona, ocratoxina A e deoxinivalenol) foi feita usando cromatografia de camada delgada, de acordo com as metodologias descritas por Soares \& Rodrigues-Amaya (1989) e Eppley et al (1986), com adaptações, como a quantificação feita através de cromatografia bi-direcional, onde o limite de detecção para as quatro aflatoxinas foi de 0,5 ? $\mathrm{g} \mathrm{kg}^{-1}$. Não foram detectadas as presenças de zearalenona, ocratoxina $\mathrm{A} e$ deoxinivalenol.

\subsubsection{Estudo histopatológico}

Aos 28 dias de ensaio, três animais de cada tratamento, que não receberam a $\mathrm{AFB}_{1}{ }^{3} \mathrm{H}$, foram anestesiados em câmara saturada com halotano, abertas as suas cavidades abdominais e removidos os seus órgãos internos removidos. Fragmentos dos fígados foram fixados em solução de formol 10\% e utilizados para o exame histopatológico.

A partir de cada uma das peças de tecido hepático dos 12 animais, foram preparadas três lâminas histológicas, conforme os procedimentos descritos por Pacheco (1981) e coradas com hematoxilina e eosina $(\mathrm{HE})$. Após o preparo, o estudo histopatológico das lâminas foi realizado ao microscópio de luz, em aumento de 16 × 1,25 x 10 (200x).

Os tecidos hepáticos dos animais que receberam dieta livre de aflatoxinas foram tomados como padrões de referência para isento de hepatotoxidez. 


\subsubsection{Radioensaio}

No $18^{\circ}$ dia do experimento, nas condições descritas anteriormente, seis animais de cada um dos tratamentos com presença de aflatoxinas (T2, T3 e T4) foram tomados, por sorteio, para a condução do radioensaio. Estes animais foram transferidos para gaiolas metabólicas e passaram por um período de cinco dias em adaptação, onde continuaram se alimentando com as mesmas dietas que estavam recebendo e água "ad libitum".

No $23^{\circ}$ dia, a $\mathrm{AFB}_{1}{ }^{3} \mathrm{H}$ diluída em $0,5 \mathrm{~mL}$ de solução aquosa de dimetil sulfóxido $8 \%$ foi ministrada aos animais por via oral, sendo que cada animal recebeu uma dose simples de 2 ? Ci. Um animal de cada tratamento foi sacrificado nos tempos de 12, 24, 48, 72, 96 e $120 \mathrm{~h}$ após a aplicação da flatoxina $B_{1}$ radiomarcada. De cada animal foram coletadas amostras de tecido muscular, rins, pulmões, coração, baço, sangue, trato gastrintestinal, fígado, fezes e urina. As excretas (fezes e a urina) foram removidas em todos os períodos de amostragens, de modo que as quantidades de materiais obtidas representassem apenas o intervalo entre uma coleta e outra. As amostras foram congeladas e armazenadas até o momento das análises.

A distribuição de radiomoléculas no organismo dos animais foi verificada através da detecção da radioatividade presente nos diversos materiais coletados. As amostras, em duplicata, com aproximadamente 50 a 300mg cada, foram submetidas à combustão em um "oxidizer" modelo "Biological Oxidizer Ox 500", da R.J. Harvey Instrument Corporation. O trítio presente em cada amostra foi coletado em $15 \mathrm{~mL}$ de água e deste volume, $10 \mathrm{~mL}$ foram transferidos para frascos de contagem, contendo $10 \mathrm{~mL}$ de solução cintiladora (INSTA GEL PLUS). A determinação da atividade foi feita por cintilação líquida, dilizando um cintilador modelo "Packard Tri-Carb 1600 TR" e o tempo de contagem de cada amostra foi de 5 minutos.

Os resultados foram expressos como \% da radioatividade na amostra em relação à \% da radioatividade aplicada recuperada. Os valores apresentados representam a radioatividade encontrada em amostras de um animal por tratamento em cada tempo de observação, totalizando seis animais por tratamento durante todo o ensaio.

Pela forma como foram coletados os dados foi feita uma análise descritiva das observações e, portanto, não foi aplicada estatística quali-quantitativa no tratamento dos resultados obtidos. 


\subsection{Resultados e discussão}

\subsubsection{Diagnóstico histopatológico}

As análises histopatológicas foram realizadas com exame de nove lâminas disponíveis por cada tratamento e em cada tratamento foi selecionada uma fotomicrografia que representasse esse conjunto. Desse modo, a seguir serão ilustrados, apresentados e discutidos os resultados obtidos no estudo histopatológico de todos os animais de cada tratamento.

A Figura 16 ilustra o tecido hepático de um animal que recebeu dieta livre de aflatoxinas (T1). Através desta figura pode-se observar que a organização celular está normal, sem a presença de degeneração e de necrose celular, além das células em degeneração fisiológica. Os resultados estão de acordo com o previsto, uma vez que os animais deste grupo não ingeriram aflatoxinas e, portanto, não deveriam apresentar hepatotoxidez. Por isso, os tecidos hepáticos dos animais do grupo T1 foram adotados como padrões de referência para investigar se os animais submetidos aos demais tratamentos apresentaram ou não os danos promovidos pela ingestão das aflatoxinas e, se os tratamentos com leveduras foram capazes ou não de diminuir os danos induzidos por tais toxinas.

A Figura 17 apresenta o aspecto do tecido hepático de um animal que recebeu dieta contaminada com aflatoxinas, na concentração de 500 ? g kg-1(T2). Através desta figura pode-se observar que os animais deste tratamento apresentaram fígados com necrose da maioria das células, com degeneração hidrópica; a veia centrolobular encontra-se congestionada, com quadro de necrose total. Estas alterações indicam a presença de efeito hepatotóxico ocasionado pela dose de aflatoxinas ministrada. Estas observações estão de acordo com os resultados descritos por Heathcote \& Hibbert (1978); Baptista et al. (2002) e Celik et al. (2003), os quais observaram desorganização celular, com proliferação de ductos biliares, necrose do parenquima hepático, vacuolização, hepatócitos inchados, degeneração hidrópica, alterações gordurosas e retenção de pigmentos ao examinarem o tecido hepático de animais que receberam dietas contaminadas por aflatoxinas. 


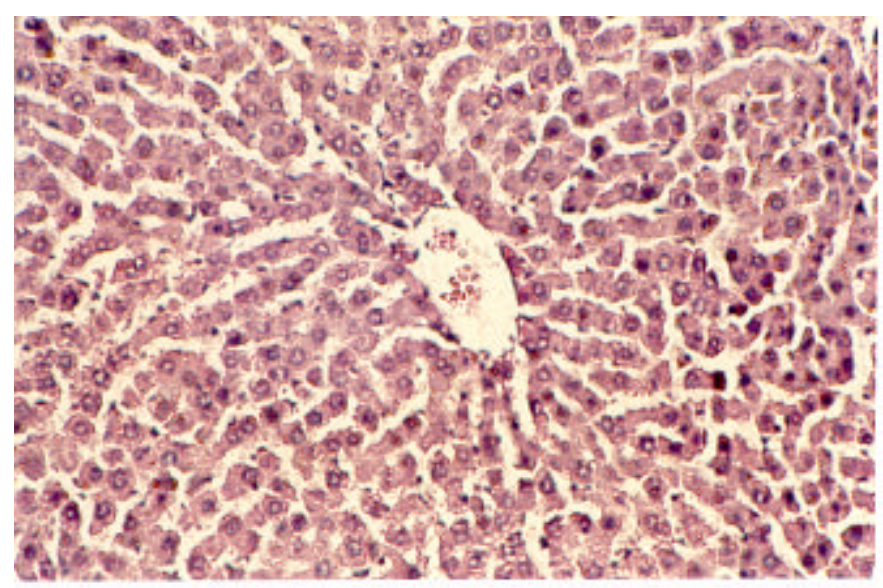

Figura 16 - Fotomicrografia do tecido hepático de rato que recebeu alimentação livre de aflatoxinas

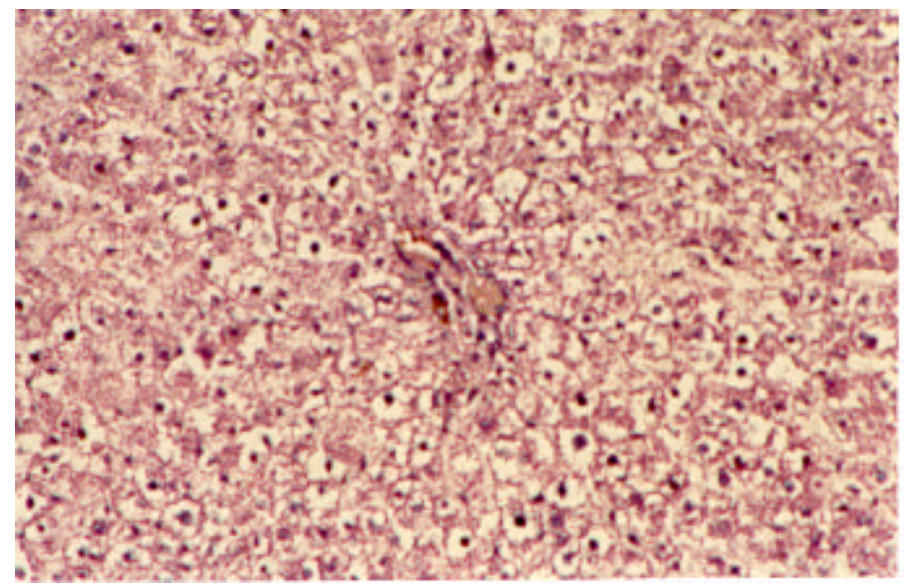

Figura 17 - Fotomicrografia do tecido hepático de rato que recebeu alimentação contaminada com $500 ? \mathrm{~g} \mathrm{~kg}^{-1}$ de aflatoxinas (aumento de 200x).

Também foi observando que os animais submetidos aos tratamentos 3 e 4, respectivamente, apresentaram tecidos hepáticos com leve grau de desorganização celular; também foi notada a ausência de células necróticas; os capilares sinusóides estava bem desenhados e as células estavam integras, sem sinais de degeneração, além das ocorrências fisiológicas normais (Figuras 18 e 19). 


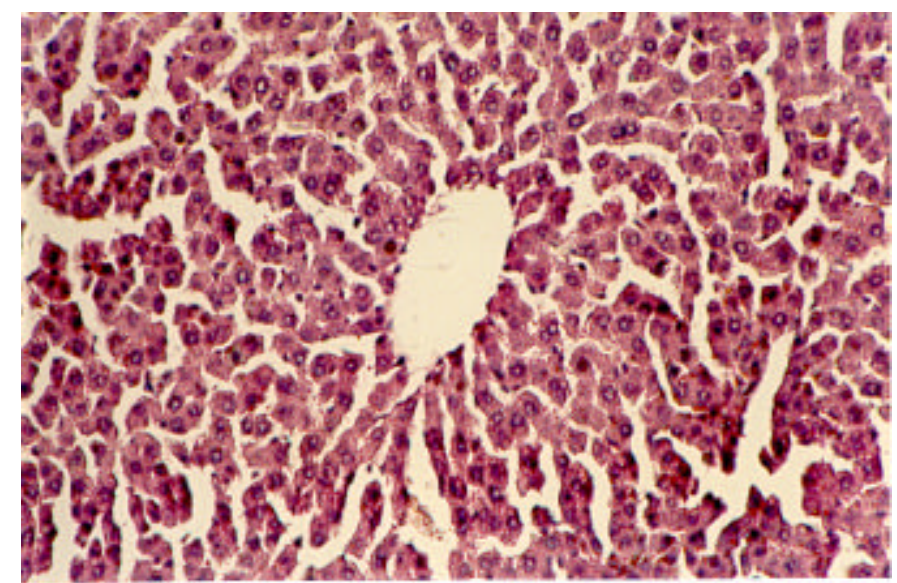

Figura 18 - Fotomicrografia do tecido hepático de rato que recebeu alimentação contaminada com 500 ?g kg-1 de aflatoxinas $+1,0 \%$ de levedura da linhagem Y1026 (aumento de 200x).

Através destas observações infere-se que os animais que receberam suplementação com as leveduras, das linhagens Y1026 e Y904, na concentração de 1,0\%, apresentaram pronunciada redução dos danos promovidos pelas aflatoxinas aos hepatócitos quando comparados com as células hepáticas dos animais do grupo controle que recebeu dieta basal mais aflatoxinas (T2). Isso indica que os tratamentos com a adição de leveduras controlaram bem as aflatoxicoses em nível celular.

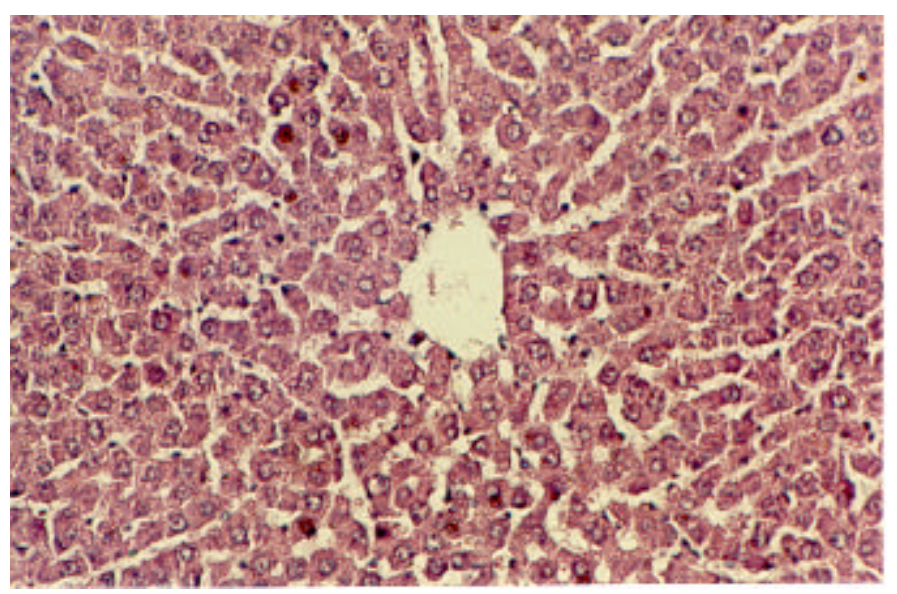

Figura 19 - Fotomicrografia do tecido hepático de rato que recebeu alimentação contaminada com 500 ? g kg-1 de aflatoxinas $+1,0 \%$ de levedura da linhagem Y904 (aumento de 200x). 
Além disso, a histologia hepática destes animais revela características bastante similares àquelas dos fígados dos animais que receberam dieta livre de aflatoxinas (Figura 16). Isso reforça os indícios de que as leveduras vivas são capazes de reduzir aflatoxicoses.

Estes resultados corroboram com os encontrados por outros autores Stanley et al. (1993); Baptista et al. (2001); Parlat et al. (2001) e Celik et al. (2003), os quais também observaram, através de estudo histopatológico, redução nos danos promovidos por aflatoxinas em animais que receberam leveduras vivas juntamente com dietas contaminadas por aflatoxinas.

\subsubsection{Radioensaio}

A Figura 20 mostra que em $12 \mathrm{~h}$ após ministrar $\mathrm{AFB}_{1}{ }^{3} \mathrm{H}$, os maiores níveis de radioatividade foram encontrados no trato gastrintestinal do animal que ingeriu a levedura Y904; nos animais que receberam a dieta controle com aflatoxina e a suplementada coma levedura Y1026 estes valores foram semelhantes entre eles. A concentração da toxina e seus produtos foram maiores no fígado dos animais do grupo controle $(25,7 \%)$ do que naquele que recebeu a Y904 (19,6\%). Além disso, a presença de radioatividade foi menor no tecido muscular do animal que recebeu dieta contendo a levedura Y904. Estes resultados indicam que nas 12 primeiras horas a absorção, a distribuição e a excreção de AFB 1 e seus metabólitos foi mais lenta nos animais que receberam a dieta suplementada com a levedura Y904. 


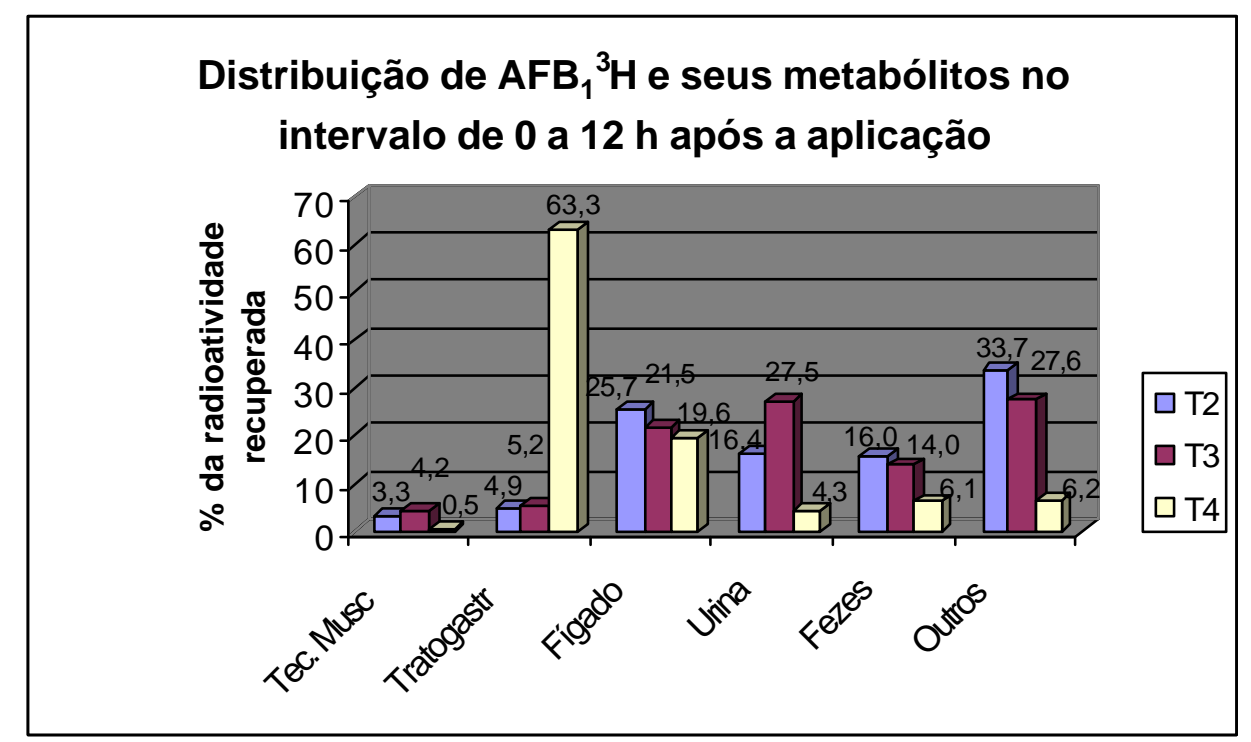

A denominação "OUTROS" representa o somatório da radioatividade de outras frações, a saber: coração, pulmões, rins, baço, sangue e perdas.

Figura 20 - Distribuição de $A F B_{1}$ e seus metabólitos no organismo e nas excretas de ratos Wistar no intervalo de 0 a $12 \mathrm{~h}$ após a aplicação da radiomolécula.

A Figura 21 demonstra que em $24 \mathrm{~h}$ depois que se ministrou a molécula marcada, os maiores teores da toxina e produtos oriundos dela foram encontrados no trato gastrintestinal dos animais que receberam a levedura $Y 1026(63,2 \%)$ e da $Y 904$ (46,6\%). A excreção da $\mathrm{AFB}_{1} \mathrm{e}$ seus metabólitos foram maiores nas fezes dos animais do grupo controle $(64,4 \%)$ do que nos demais tratamentos.

A atividade específica foi mais elevada no fígado do animal que recebeu a dieta com a levedura Y904. Estes resultados indicam que a absorção e a catabolização de $\mathrm{AFB}_{1}$ e seus derivados no trato gastrintestinal e no fígado foram mais lentas nos animais que receberam 0 probiótico. Isso significa que o efeito da levedura sobre a aflatoxina se inicia no aparelho digestório. 


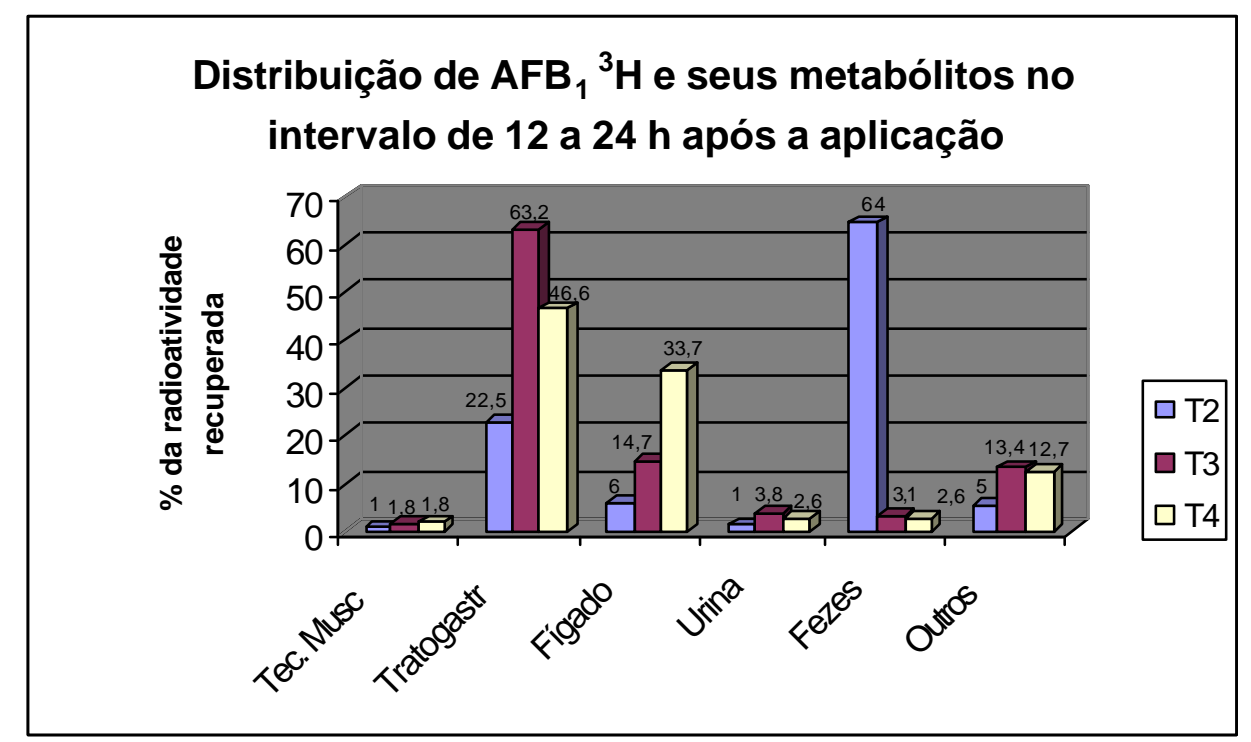

A denominação "OUTROS" representa o somatório da radioatividade de outras frações, a saber: coração, pulmões, rins, baço, sangue e perdas.

Figura 21 - Distribuição de $\mathrm{AFB}_{1}$ e seus metabólitos no organismo e nas excretas de ratos Wistar no intervalo de 12 a 24 h após a aplicação da radiomolécula.

Em 48h após ministrar o radionuclídeo, as maiores quantidades de material radioativo foram observadas nas fezes e os maiores valores (82\%) foram observados nos animais do grupo controle; as fezes dos animais que receberam as leveduras Y1026 e Y904 também apresentaram altos níveis de radioatividade $(68,7 \%)$ e $(57,4 \%)$, respectivamente. Também foi verificado que no trato gastrintestinal de animais que receberam os aditivos havia a presença de maior quantidade de $A B F_{1}{ }^{3} \mathrm{H}$ e seus metabólitos (16,1 e 10,7\%) para as linhagens Y1026 e Y904, respectivamente (Figura 22).

Além disso, também foi observada maior eliminação de radiomoléculas através da urina de animais que ingeriram leveduras do que naqueles que não receberam tais tratamentos. A presença de material marcado foi maior no tecido muscular daqueles animais que receberam apenas a dieta controle com aflatoxina $\mathrm{B} 1{ }^{3} \mathrm{H}$ do que nestes tecidos daqueles que ingeriram leveduras. 


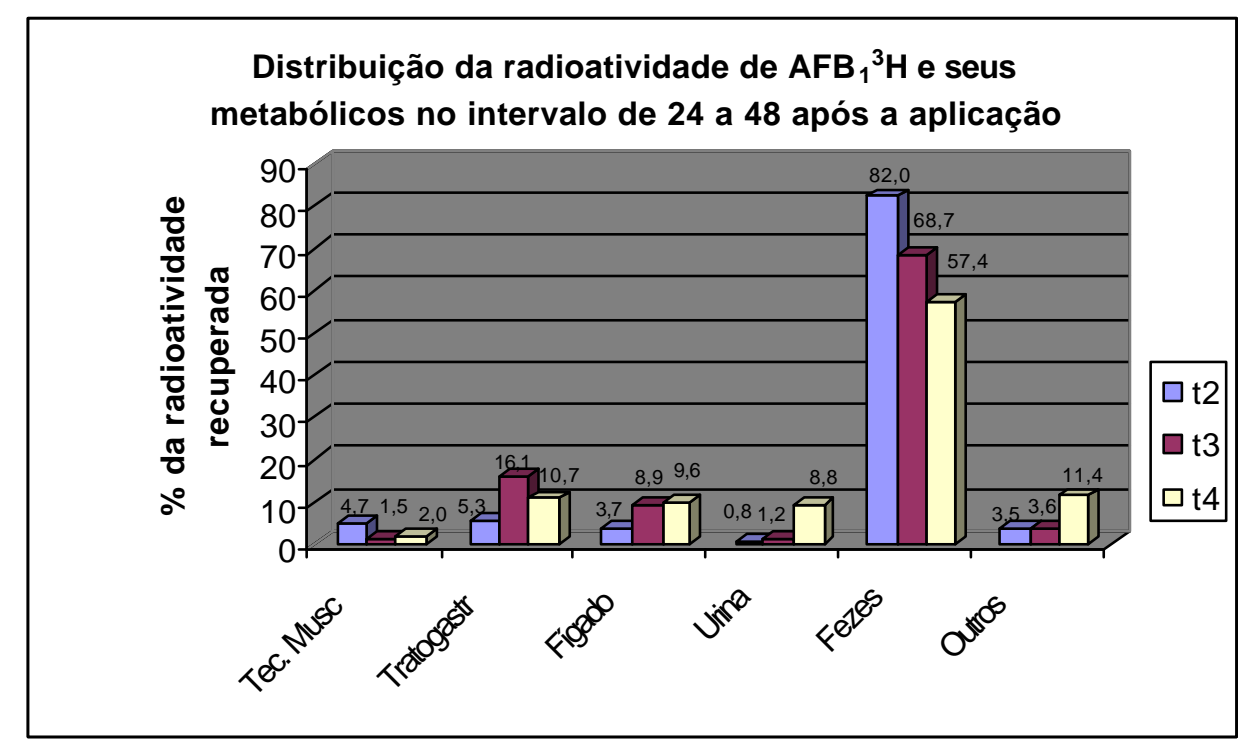

A denominação "OUTROS" representa o somatório da radioatividade de outras frações, a saber: coração, pulmões, rins, baço, sangue e perdas.

Figura 22 - Distribuição de $\mathrm{AFB}_{1}$ e seus metabólitos no organismo e nas excretas de ratos Wistar no intervalo de 24 a $48 \mathrm{~h}$ após a aplicação da radiomolécula.

No intervalo de 48 a $72 \mathrm{~h}$ foi observado que a maior quantidade de $\mathrm{AFB}_{1}$ e produtos derivados do seu metabolismo foi encontrada nas fezes do animal que recebeu a dieta contendo a levedura Y1026, 81,6\% (Figura 23). 


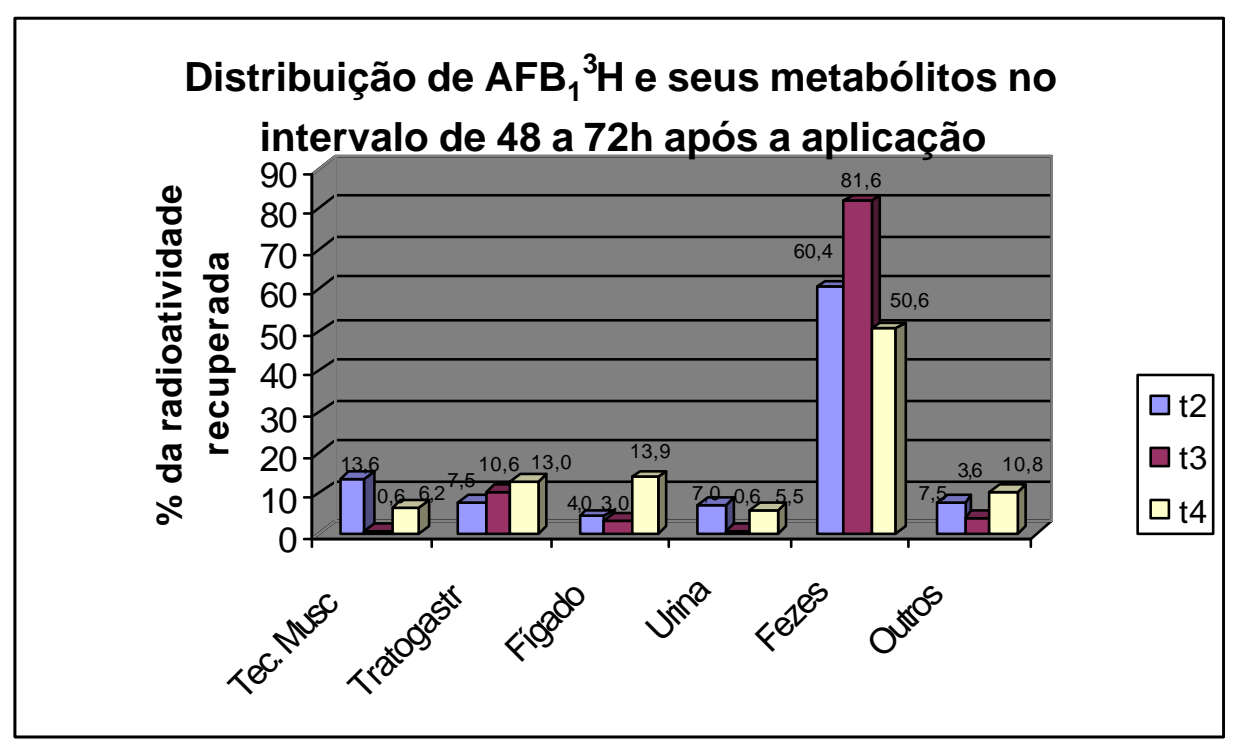

A denominação "OUTROS" representa o somatório da radioatividade de outras frações, a saber: coração, pulmões, rins, baço, sangue e perdas.

Figura 23 - Distribuição de $A F B_{1}$ e seus metabólitos no organismo e nas excretas de ratos Wistar no intervalo de 48 a 72 h após a aplicação da radiomolécula.

Foram verificados ainda que os maiores níveis de radioatividade nos tratos intestinais dos indivíduos que ingeriram os probióticos (13 e 10,6\% nas leveduras Y904 e Y1026, respectivamente) do que no grupo controle (7,5\%).

As maiores concentrações de compostos marcados com ${ }^{3} \mathrm{H}$ foram observadas no tecido hepático do animal que recebeu a levedura Y904 do que nos animais submetidos aos demais tratamentos. Ademais, a quantidade de radiomoléculas foi maior no tecido muscular de animais do grupo controle do que nos animais que receberam os outros tratamentos.

A eliminação de $\mathrm{AFB}_{1}{ }^{3} \mathrm{H}$ e seus metabólitos através das fezes foram próximos de $40 \%$ nos animais de todos os tratamentos. Contudo, maior concentração de material marcado foi encontrada no fígado e no trato gastrintestinal de animais que não ingeriram dietas contendo leveduras vivas. Além disso, a presença de radiomoléculas no tecido muscular foi maior nos animais do grupo controle. Os níveis de radioatividade nas urinas dos animais que foram alimentados com as leveduras Y904 e Y1026 foram semelhantes às dos animais do grupo controle (Figura 24). 


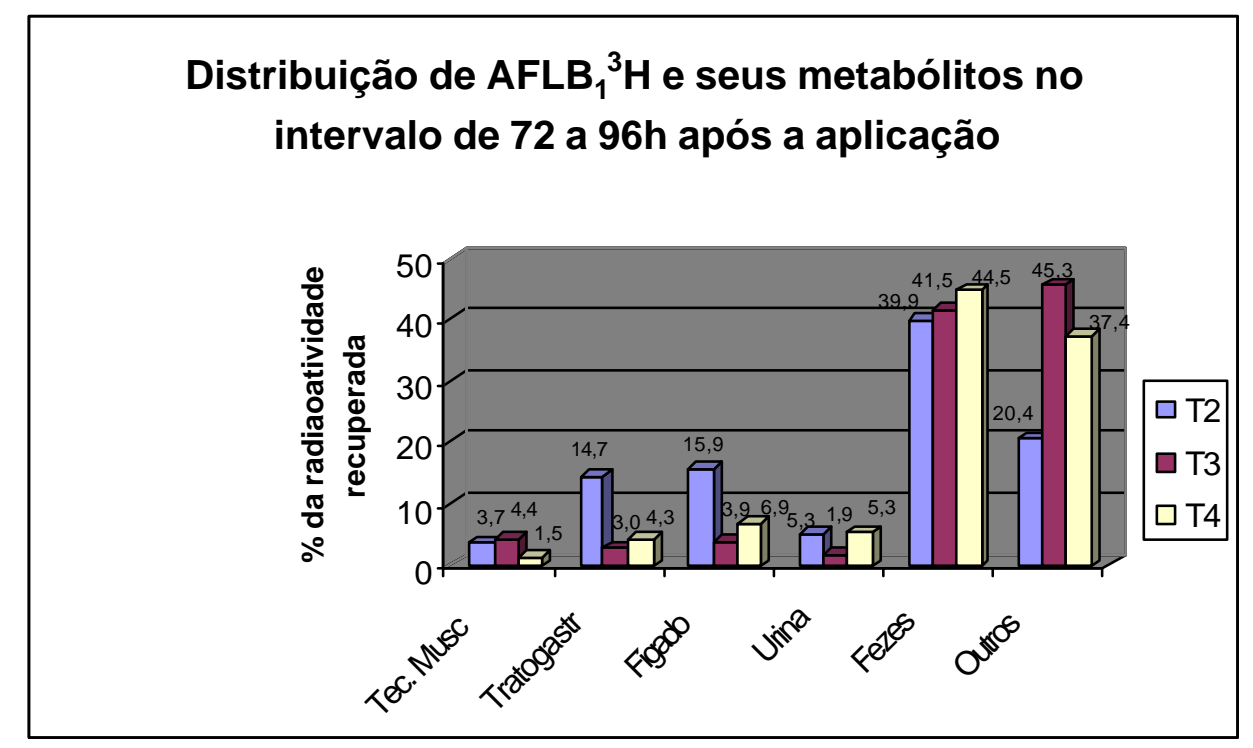

A denominação "OUTROS" representa o somatório da radioatividade de outras frações, a saber: coração, pulmões, rins, baço, sangue e perdas.

Figura 24 - Distribuição de $\mathrm{AFB}_{1}$ e seus metabólitos no organismo e nas excretas de ratos Wistar no intervalo de 72 a 96 h após a aplicação da radiomolécula.

A radioatividade por grama de material foi maior nas fezes dos animais, em todos os tratamentos, nas quais foram encontradas radioatividades na faixa de 40 a $44 \%$. A eliminação via urina variou de 3,3 a 5,7\% nos animais dos grupos que receberam a levedura Y904 e 0 controle, respectivamente. Nos tecidos hepáticos foram observadas quantidades de materiais marcados que variaram de 8 a 13,2\%. A presença de $A F B_{1}$ e seus produtos foram maiores no trato gastrintestinal de animais que receberam os aditivos. Por outro lado, es resíduos de radiomoléculas nos tecidos musculares foram ligeiramente maiores no animal que não recebeu 0 probiótico (Figura 25). 


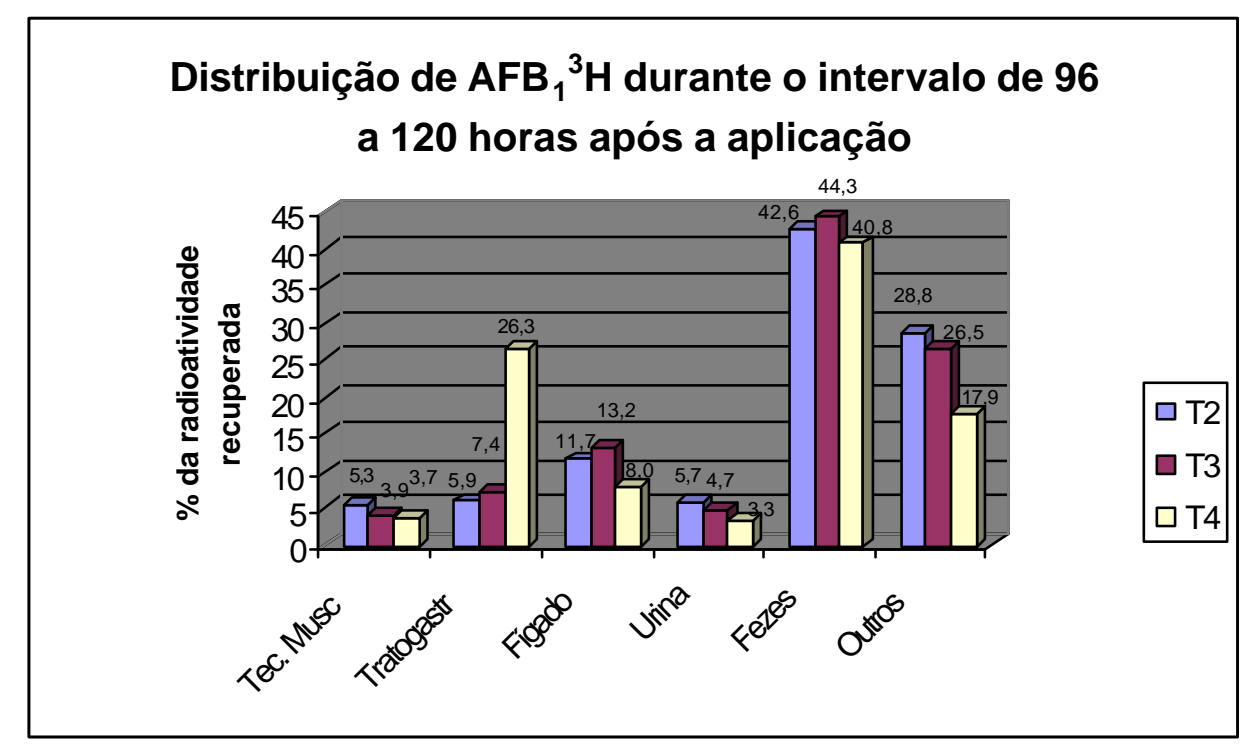

A denominação "OUTROS" representa o somatório da radioatividade de outras frações, a saber: coração, pulmões, rins, baço, sangue e perdas.

Figura 25 - Distribuição de AFB 1 e seus metabólitos no organismo e nas excretas de ratos Wistar no intervalo de 96 a 120 h após a aplicação da radiomolécula.

Durante as $120 \mathrm{~h}$ do radioensaio foi verificado que $68,5 \%$ de $\mathrm{AFB}_{1}{ }^{3} \mathrm{H}$ e seus metabólitos haviam sido eliminados através das fezes nos animais que receberam a dieta sem leveduras (Figura 26A). Também foi observado que os animais que receberam dietas contendo leveduras vivas, Y1026 e Y904, eliminaram via fezes 62,7 e $24,3 \%$ do material marcado, respectivamente (Figuras 26B e 26C). A eliminação da radioatividade via urina foi de $4,6 \%$ nos animais que receberam a levedura Y904 e nos indivíduos dos grupos T2 e T3 os valores das eliminações foram de 3 e 2,5\%, respectivamente. É importante ressaltar que 0 acúmulo de radiomoléculas foi maior nos tratos intestinais de animais que receberam a levedura Y904 (38,1\%) e Y1026 (17,4\%) do que nos animais que não tiveram a suplementação alimentar com o probiótico (T2 - 10,1\%). A presença de material radioativo também foi maior no fígado dos animais do grupo de T3 (7,9\%) e T4 (18,6\%) do que neste órgão dos animais do grupo controle, T2 (5,9\%). 


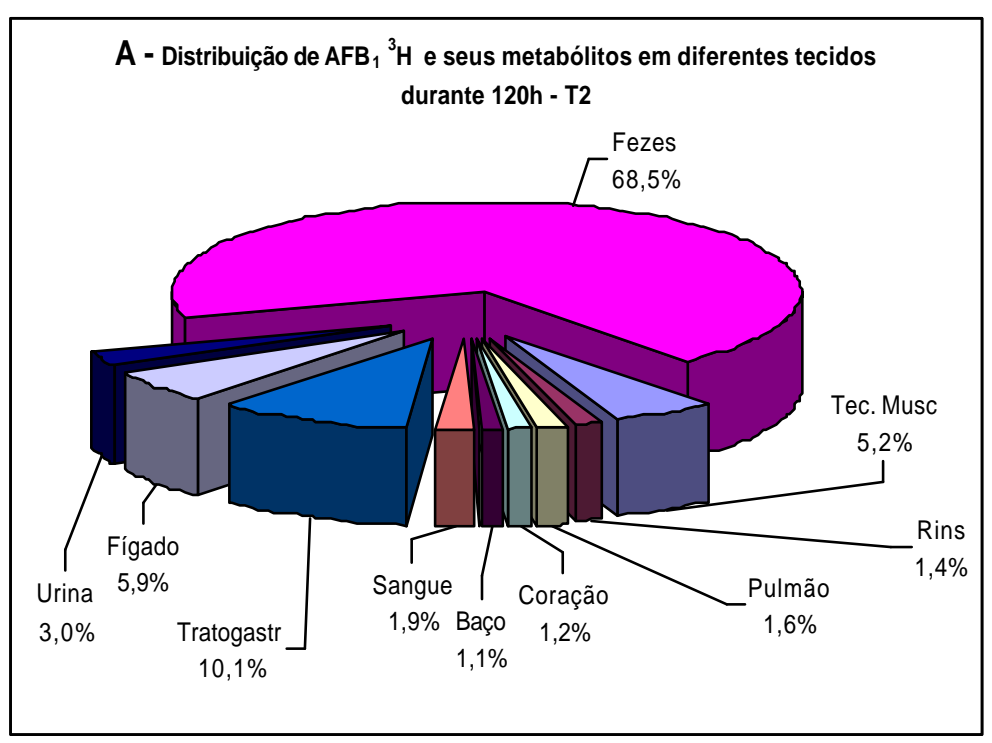

C- Distribuição de $\mathrm{AFB}_{1}{ }^{3} \mathrm{H}$ e seus metabólitos em diferentes tecidos durante $120 \mathrm{~h}$ - T4

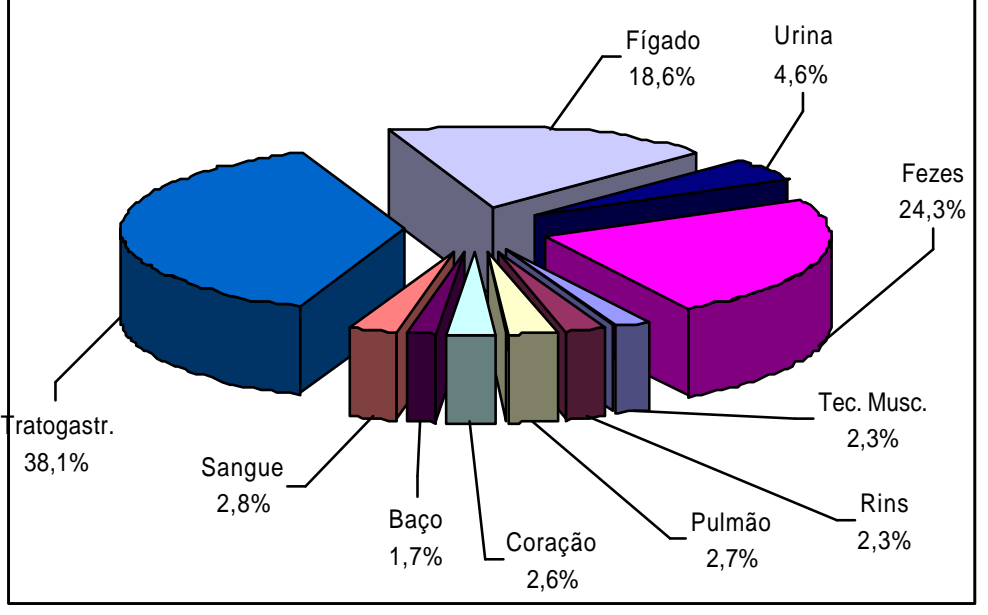

B - Distribuição de $\mathrm{AFB}_{1}{ }^{3} \mathrm{H}$ e seus metabólitos em diferentes tecidos durante $120 \mathrm{~h}-\mathrm{T} 3$

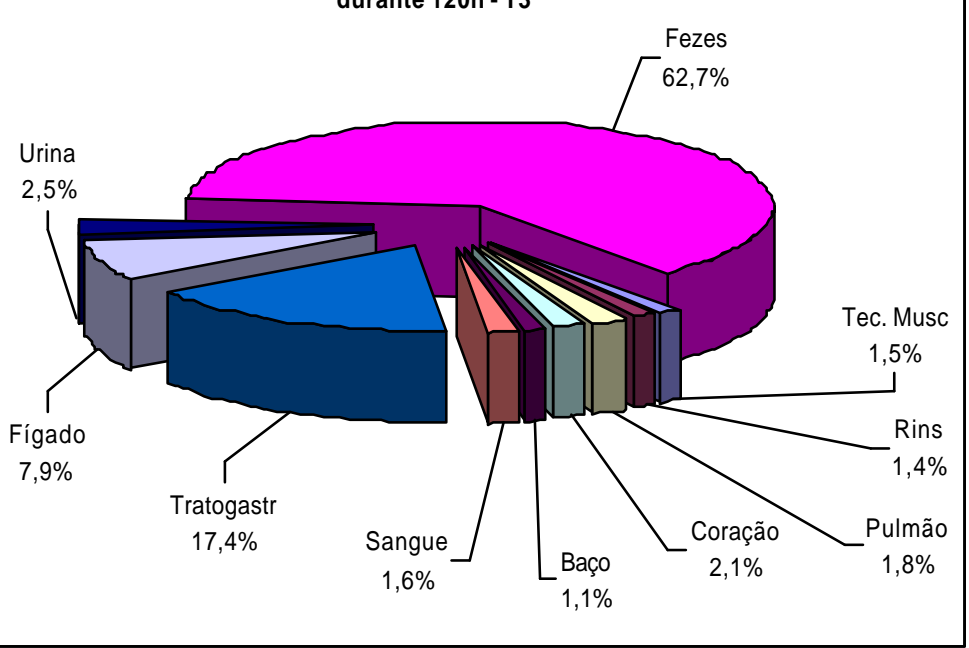

Figura 26 - (A) Distribuição de $\mathrm{AFB}_{1}{ }^{3} \mathrm{H}$ e seus metabólitos em animais do grupo controle com aflatoxina - T2, acumulada em 120h após a aplicação; (B) Distribuição de AFB ${ }^{3} \mathrm{H}$ e seus metabólitos em animais do grupo que recebeu a levedura Y1026 - T3, acumulada em 120h após a aplicação; e, (C) Distribuição de $\mathrm{AFB}_{1}{ }^{3} \mathrm{H}$ e seus metabólitos em animais que ingeriram a levedura Y904 - T4, acumulada em 120h após a aplicação; 
Além disso, podem-se notar que os tecidos musculares dos animais do grupo controle foram aqueles que apresentaram maiores teores da toxina e seus derivados, aproximadamente três vezes os valores obtidos nestes tecidos em animais dos outros grupos. Estes resultados indicam que a presença de leveduras vivas na dieta promoveu alteração na absorção, na distribuição e na eliminação da aflatoxina $B_{1}$ e seus produtos do organismo. Ademais, que 0 acúmulo de radiomoléculas no tecido muscular foi reduzido pela ação das leveduras.

Estas alterações podem ser pelo seqüestro da toxina ou mudança na biotransformação da mesma. Para elucidar tais dúvidas seria necessário o estudo sobre qual é o produto formado pela aflatoxina $B_{1}$ ou se esta permanece inalterada no organismo, ou seja, se sofre alguma biotransformação formando algum produto secundário ou se é apenas aprisionada no trato gastrintestinal.

Os resultados obtidos nesta investigação estão de acordo com aqueles encontrados por outros autores (Wogan et al., 1967; Dalezios et al., 1973; Luthy et al., 1980; Helferich et al., 1986; Kumagai et al., 1998; Ellis et al., 2000), os quais verificaram que a absorção de aflatoxinas em ratos e outros animais acontecia poucos minutos após a sua aplicação. Estes autores também verificaram que a maior parte da radioatividade da $\mathrm{AFB}_{1}$ radiomarcada era eliminada via fezes e urina e, que as fezes apresentavam a maior contribuição na excreção de aflatoxinas e seus metabólitos do que a urina. Além disso, os mesmos pesquisadores relataram que o principal órgão atingido era o fígado e que o mesmo acumulava níveis de aflatoxinas maiores do que outros órgãos.

Estas informações indicam que a absorção, a distribuição e a excreção de AFB $_{1}{ }^{3} \mathrm{H}$ e/ou seus metabólitos foi mais lenta em animais que receberam dietas contendo as leveduras das linhagens Y904 e Y1026. Inicialmente, algumas hipóteses poderiam ser levantadas para explicar tais observações. Baseando-se no enunciado Yiannikouris et al. (2003), podia se acreditar que a levedura seqüestrasse a aflatoxina e em seguida promovesse a sua eliminação sem ser absorvida no trato gastintestinal, o que não foi verdade, pois se nota a presença de radioatividade em diversos tecidos e órgãos durante todo o ensaio. Outra hipótese, baseada nos relatos de Krause et al.(1989); Cumplen et al. (1989) e Baptista et al (2004), os quais observaram que adição de leveduras vivas pode promover 0 aumento na atividade de certas enzimas e com isso fazer com que reações que levem à formação de moléculas conjugadas com as aflatoxinas, as 
quais segundo Swenson et al. (1974); Hieh (1987); Hayes et al. (1991) podem ser com aminoácidos, sulfatos ou glutationa. A glutationa chama bastante atenção pelo fato de que as leveduras podem ser usadas como fontes de glutationa-S-transferase, em função dos altos níveis que apresentam (Desmonts, 1966; Alfafara et al., 1992; 1992b).

A inferência de que a levedura de alguma forma consegue tornar a aflatoxina menos tóxica pode ser defendida pelos resultados obtidos no estudo histopatológico, no qual foi verificado que a levedura presente na dieta contaminada teve efeito protetor contra os danos induzidos pelas aflatoxinas. Portanto, com base nos estudos radioquímicos e histopatológicos se acredita que a hipótese mais provável sobre o modo de ação das leveduras sobre os danos induzidos por aflatoxinas seja que ela atue na biotransformação da aflatoxina no organismo, de modo que promova a formação de compostos menos tóxicos, principalmente, com a aflatoxina na forma epóxido. Para elucidar tais dúvidas seria necessário, além do estudo radioquímico, a identificação das moléculas formadas a partir da $\mathrm{AFB}_{1}{ }^{3} \mathrm{H}$. Isso poderia ser feito com auxílio das técnicas de espectrometria de massas, de ressonância magnética nuclear e de infravermelho ou com uso de cromatografia, utilizando padrões autênticos dos metabólitos possíveis de serem gerados pela biotransformação de aflatoxinas e alguma técnica auxiliar para a identificação de moléculas sem padrões disponíveis.

Finalmente, pode-se dizer que as leveduras vivas parecem ter propriedades biológicas, as quais modificam a absorção de $\mathrm{AFB}_{1}$ no trato gastrintestinal e que a ação destas promove a redução dos danos promovidos por esta micotoxina. Estas informações estão de acordo com as observações feitas por outros autores em estudos sem o uso de radiotraçadores (Stanley et al.,1993; Celik et al., 2001; Baptista et al., 2004), os quais observaram efeito protetor de leveduras vivas sobre os danos biológicos e bioquímicos ocasionados pela ingestão de aflatoxinas. 


\subsection{Conclusões}

A levedura atuou modificando a absorção da aflatoxina $B_{1}$ no trato gastrintestinal;

A eliminação de aflatoxinas e seus metabólitos via fezes e urina foi mais lenta em animais que ingeriram leveduras;

O acúmulo de aflatoxinas e seus produtos foram menores no tecido muscular de animais que foram alimentados com leveduras;

As leveduras das linhagens Y904 e Y1026 foram capazes de reduzir as aflatoxicoses em ratos Wistar. 


\section{CONCLUSÕES}

Leveduras da espécie Saccharomyces cerevisiae de diferentes linhagens apresentam capacidade de reduzir os danos ocasionados pela ingestão de aflatoxinas e que 0 enriquecimento com aminoácidos potencializa o efeito protetor das leveduras contra as aflatoxicoses;

A dose de levedura Y1026 utilizada em dietas contaminadas com aflatoxinas apresenta efeito determinante na eficácia do controle de aflatoxicoses;

A presença de leveduras em dietas contaminadas com AFB 1 modifica a absorção, a distribuição e a excreção desta aflatoxina e/ou seus metabólitos e, além disso, reduz os danos ocasionados por tais toxinas. 


\section{REFERÊNCIAS}

ALFAFARA, C.; MIURA, K.; SHIMIZU. H.; SHIOYA, S.; SUGA, K. Cysteine addition strategy for maximum glutathione production in fed-batch culture of Saccharomycescerevisiae. Applied Microbiology and Biotechnology, Berlin, v.37, n.2, p.141-146, 1992a.

ALFAFARA, C.G.; KANDA, A.; SHIOI, T.; SHIMIZU, H.; SHIOYA, S.; SUGA, K. Effect of aminoacids on glutathione production by Saccharomyces cerevisiae. Applied Microbiology and Biotechnology, Berlin, v.36, n.4, p.538-540, 1992b.

ANGIER, N. A stupid cell with all the answers. Discover, New York, v.7, n.11, p.71-83, 1986.

BAPTISTA, A. S.; HORII, J.; GLORIA, E. M.; DOMINGUES-CALORI, M. A.; VIZIOLI, M. R. Saccharomyces cerevisiae in the reduction of the aflatoxins effects. European Journal of Phamaceutical Sciences, Amsterdam, v.13 (Sup.1), S.48, 2001.

BAPTISTA, A.S.; HORII, J.; CALORI-DOMINGUES, M. A.; GLÓRIA, E. M.; SALGADO, J. M.; VIZIOLI, M. R. The capacity of mannanoligosaccharides, thermolysed yeast and active yeast to attenuate aflatoxicosis. World Journal Microbiology and Biotechnology, Dordrecht, v. 20, n.5, p. 475-481, 2004.

BAPTISTA, A.S.; HORII, J.; CALORI-DOMINGUES, M. A.; GLÓRIA, E. M.; SALGADO, J. M.; VIZIOLI, M. R. Utilization of thermolysed and active yeast to reduce the toxicity of aflatoxin. Scientia Agricola, Piracicaba, v.59, n.2 , p.257-260, 2002.

BARNES, J. M.; BUTLER, W. H. Carcinogenisis activity of aflatoxin in rats. Nature, London, v.202, n.493, p.1016, 1964. 
BENITEZ, T.; GASENT-RAMIRES, J. M.; CASTREJÓN; CODÓN, C. A. Development of new strains in food industry. Biotechnology Progress, New York, v.12, p.149-163, 1996.

BEUDEKER, R. Developments in barker's yeast production. In: VERACHETERL, H. \& DE MOT, R. Yeast: biotechnology and biocatalysis. New York: Marcel Dekker, 1990. p.103-146.

BHATTACHARJE, J. K. Microorganism as potential sources of food. Advances in Applied Microbiology, New York, v.13, p.139-161, 1970.

BLOKSMA, N.; DE HEER, E.; VAN DIJK, H.; WILLERS, J.M. Adjuvancy of lactobacilli. I. Differential effects of viable and killed bacteria. Clinical and Experimental Immunology, Oxford, v.37, n.2, p.367-375, 1979.

BOSSIER, P.; FERNANDES, L.; MORGADO, C. The molecular genetics of thermotolerance in yeast. Mededelingen Faculteit Landbouwkundige en Toegepaste Biologishe Wetenschappen Universteit Gent, v.58, n.4b, p.1911-9, 1993. /Resumo em AGRIS Abstracts on CD-ROM, v.6, 1993-95/.

BOTTRILL, K. The use of biomarkers as alternatives to current animals tests on food chemicals. Atla, Nottingham, v.26, p.421-480, 1998.

BOUTON, S. L.; DICK, J. W.; HUGHES, B. L. Effects of dietary aflatoxin inammonia-inactivated aflatoxin on Newcastle disease antibody titers in layer-breeders. Avian Diseases, Ithaca, v.26, n.1, p.1-5, 1980.

BRADBURN, N.; COKER, R. D. Aflatoxin contamination in maize. Tropical Science, London, v.33, n.44, p.418-428, 1993.

BRASIL. Leis, decretos, etc. Ministério da Agricultura. Portaria n.183, de 21 de março de 1996.

Diário Oficial da União, Brasília, 25 de março de 1996. Art.1. Adotar Regulamento Técnico MERCOSUL sobre Limites Máximos de Aflatoxinas Admissíveis no Leite, Amendoim e Milho, aprovado pela Resolução do Grupo Mercado Comum do Sul n.56/94, de 01 de janeiro de 1996. 
BRASIL. Ministério da Saúde. Comissão Nacional de Normas e Padrões para Alimentos. Resolução № 34.176 publicada no Diário Oficial da União de 19 de janeiro de 1977. In: ASSOCIAÇÃO BRASILEIRA DAS INDÚSTRIAS DE ALIMENTAÇÃO. Compêndio da legislação de alimentos. São Paulo:ABIA, 1991. v.1A.

BUTOLO, J. E. Uso da levedura desidratada na alimentação de aves. In: SIMPÓSIO SOBRE TECNOLOGIA DA PRODUÇÃO DE LEVEDURA DESIDRATADA NA ALIMENTAÇÃO ANIM.AL, Campinas, 1997. Anais. Campinas: CBNA, 1997. p.51-83.

CARNAGHAN, R. B.; HARTLEY, R. D.; OKELLY, J. Toxicity of fluorescence properties of the aflatoxins. Nature, London, v.200, n.491, p.1101, 1963.

CARPENTER, J. F.; CROWE, L. M.; CROWE, J. H. Stabilization of phosphofructokinase with sugars during freeze-drying-characterization of enhanced protection in the presence of divalent-cations. Biochimica et Biophysica Acta, Amsterdam, v.923, n.1, p.109-115, 1987

CELIK, K.; DENLI, M.; RTURK, M.; OZTURKCAN. O.; DORAN F. Evaluation of dry yeast (Saccharomyces cerevisiae) compounds in the feed to reduce aflatoxin B-1 (AFB(1)) residues and toxicity to Japanese quails (Coturnix coturnix japonica). Journal of Applied Animal Research, v.20, n.2, p.245-250, 2001.

CELIK, K.; DENLY, M.; SAVAS, T. Reduction of toxic effects of aflatoxin $B_{1}$ by using baker yeast (Saccharomyces cerevisiae) in growing broiler chicks diets. Revista Brasileira de Zootecnia, Viçosa, v.32, n.3, p.615-619, 2003.

CHARMLEY, L. L.; TRENHOLM, H. L.; PRELUSKY, D. B.; ROSEMBURG, A. Economics losses and decontamination. Natural Toxins, New York, v.3, p.199-2003, 1995.

CLIFFORD, J. I.; REES, K. R. The action of aflatoxin $\mathrm{B}_{1}$ on the rat liver. Biochemistry Journal, Colchester, v.102, p. 65-75, 1967.

CROWE, J. H.; CARPENTER, J. F.; CROWE, L. M. The role of vitrification in anhydrobiosis. Annual Review of Physiology, Palo Alto, v.60, p.73-103, 1998. 
CROWE, L. M.; MOURADIAN, R.; CROWE, J. H. et al. Effect of carbohydrates on membrane stability at low water activities. Biochimica et Biophysica Acta, Amsterdam, v.769, p.14150, 1984.

CRUMPLEN, R.; D'AMORE, T.; PANCHAL, C. J.; RUSSELL, I.; STEWART, G. G. Industrial uses of yeast: Present and Future. Yeast, Chichester, v.5, p.3-9, 1989. Special issue.

CUPID, B. C.; LIGHTFOOT, T. J.; RUSSELL, D.; GANT; S. J.; TURNER, P. C.; DINGLEY, K. H.; CURTIS, K. D.; LEVESON, S. H.; TURTELTAUB, K. W.; GARNER, R. C. The formation of AFB1-macromolecular adducts in rats and humans at dietary levels of exposure. Food and Chemical Toxicology, London, v.42, p. 559-569, 2004.

CYSEWSKI, S. J.; WOOD, R. L.; PIER, A.C.; et al. Effects of aflatoxin on the development of acquired immunity to Swine erypselas. American Journal of Veterinary Research, Chicago, v.39, n.3, p.445-448, 1978.

DALEZIOS, J. I.; HSIEH, D. P. H.; WOGAN, G. N. Excretion and metabolism of orally administered aflatoxin-B1 by rhesus-monkeys. Food and Cosmetics Toxicology, London, v.11, n.4, p.605-616, 1973.

DALVI, R. R.; McGOWAN, C. Experimental induction of chronic aflatoxicosis in chickens by purified aflatoxin $B_{1}$ and its reversal by actived charcoal., phenobarbitol, and reduced glutathione. Poultry Science, Ithaca, v.63, n.3, p.485-491, 1984.

DEGEN, G.H.; NEUMANN, H. G. Major metabolite of aflatoxin-b1 in rat is a glutathione conjugate. Chemico-Biological Interactions, Amsterdam, v.22, n.2-3, p.239-255, 1978.

DESMONTS, R. Tecnologia da produção dos fermentos secos de destilaria. Boletim Informativo da Associação Paulista de Medicina, Piracicaba, v. 8, n.2, p.1, 1966.

DEVEGOWDA, G.; ARAVIND, B. I. R.; MORTON, M. G. Saccharomyces cerevisiae and manannanoligosaccharides to counteract aflatoxicosis in brolers. Proceedings Australian Poultry Sciences Symposium, v.8, p.103-106, 1996. 
DICKENS, F.; JONES, E. H. The carcinogenic action of aflatoxin after its subcutaneous injection in the rats. British Journal of Cancer, London, v.17, n.4, p.691-8, 1963.

DONNINI, C.; PUGLISI, P. P.; VECLI, A.; MARMIROLI, N. Germination of Saccharomyces cerevisiae ascospores without trehalose mobilization as reveled by in vivo ${ }^{13} \mathrm{C}$ nuclear magnetic resonance spestroscopy. Journal of Bacteriology, Baltimore, v.170, n.8, p.378991, 1988.

EDDS, G. T.; BORTELL, R. A. Biological effects of aflatoxins: Poultry aflatoxin and Aspergillus flavus in corn. In: DIENER, U. L.; ASQUITZ, R. L.; DICKENS, J. W. (Ed.) Alabama: Agricultural Experiment Station, Auburn University, 1983. p.64-66. (Bulletin of the Alabama Agricultural Experiment Station).

ELLIS, R. W.; CLEMENTS, M.; TIBBETTS, A.; WINFREE, R. Reduction of the bioavailability of 20 mgrkg aflatoxin in trout feed containing clay. Aquaculture, Amsterdam, v.183, p.179$188,2000$.

ELLIS, W. O.; SMITH, J. P.; SIMPSON, B. K.; et al. Aflatoxins in food: occurrence, bio synthesis, effects on organisms, detection, and methods of control. Critical Reviews in Food Science and Nutrition, Boca Raton, v.30, n.4, p.403-439, 1991.

EPPLEY, R. M.; TRUCKNESS, M. W.; NESHEIM, S.; THORPE, C. W.; POHLAND, A. E. Determination of deoxynivalenol in wheat - collaboraty study. Journal of the AOAC, Washington, v.69, p.37-40, 1986.

EWASKIEWICZ, J. I.; DEVLIN, T. M.; CHIH, J. J . The in vivo disposition of aflatoxin-b1 in ratliver. Biochemical and Biophysical Research Communications, New York, v.179, n.2, p.1095-1100, 1991.

FAO. Sampling plans for aflatoxin analysis in peanuts and corn. Roma, 1993. 75p. 
FERNANDES, C. F.; SHAHANI, K. M.; AMER, M. A. Therapeutic role of dietary lactobacilli and lactobacillic fermented dairy products. FEMS Microbiology Reviews, Amsterdam, v.46, p.343-356, 1987.

FERNANDEZ, A.; HERNANDEZ. M.; VERDE, M. T.; SANZ, M. Effect of aflatoxin on performance, hematology, and clinical immunology in lambs. Canadian Journal of Veterinary Research, Ottawa, v.64, n.1, p. 53-58, 2000.

FINUCANE, M. P.; SPRING, P.; NEWMAN, K. E. Incidence of mannose sensitive adhesins en enteric pathogens. In: SOUTHERN POULTRY SCIENCE, 18., Atlanta, 1999. Poster. Atlanta: 1999. p.21

FONSECA, H. Envenenamento alimentar - micotoxinas e micotoxicoses. In: CAMARGO, R. et al. Tecnologia dos produtos agropecuários - Alimentos. São Paulo: Nobel, 1984. cap.4, p.51-71.

FORTNUM, B. A. Effect of environment on aflatoxin development in prehavest maize. In: WORKSHOP ON AFLATOXIN IN MAIZE, El Batan, 1986. Proceedings. El Batan: CIMMYT, 1986. p.145-51.

FRISVAD, J. C.; THRANE, U. Mycotoxin production by food -borne fungi. In: SAMSON, R.A. et al. Introduction to food-borne fungi. Dordrecht: CBS, 1996. cap 4, p.251-260.

FULLER, R. E. History and development of probiotics. In: FULLER, R. (Ed.) Probiotics - the scientific basis. London: Chapman and Hall, 1992. p.1-8.

GALVANO, F.; PIVA, A.; RITIENI, A.; GALVANO, G. Dietary strategies to counteract the effects of mycotoxins: A review. Journal of Food Protection, lowa, v.64, n.1, p.120-131, 2001. 
GARCIA, R. P.; PADILLA, C. L.; SIDIK, M.; REJESUS, B. M.; GARCIA, R. P.; CHAMP, B. R.; BENGSTON, O. S.; DHRAMAPUTA, O. S.; HALID, H. Mycotoxins and its significance in the implementation of general agreement on tariff and trade (Gatt). In: SYMPOSIUM IN PEST MANAGEMENT FOR STORED FOOD AND FEED, Bogor, Indonesia, 1995. Proceedings. Bogor, 1997. BIOTROP Special publication, v.59, p.33-51, 1997.

GAWAI, K. R.; VODELA, J. K.; DALVI, P. S.; DALVI, R. R. Comparative-assessment of the effect of aflatoxin-b1 on hepatic-dysfunction in some mammalian and avian species. Comparative Biochemistry And Physiology GPharmacology Toxicology \& Endocrinology, Oxford, v.101, n.2, p. 415-418, 1992.

HAMILTON, P. B. Determining safe concentrations of mycotoxins. Journal of Food Protection, lowa, v.47, n.7, p.570-575, 1984.

HARVEY, R. B.; HUFF, W. E.; JUBENA, L. F.; CORRIER, D. E.; PHILLIPS, T. D. Progression of aflatoxicosis in Growing barrows. American Journal of Veterinary Research, Chicago, v.49, n.4, p.482-487, 1988.

HAYES, A.W. Mycotoxin teratogenicity and mutagenicity. Boca Raton: CRC Press, 1981.

HAYES, J. D.; JUDAH, D.J .; MCLELLAN, L. I.; NEAL, G. E. Contribution of the glutathione s transferases to the mechanisms of resistance to aflatoxin $\mathrm{B}_{1}$. Pharmacology Therapeutic, London, v. 50, p.443-472, 1991.

HEATHCOTE, J. G. Aflatoxins and related toxins. In: BETINA, V. (Ed) Mycotoxins - Production, isolation, separation and purification. Amsterdam: Elsevier, 1984. p.89-130.

HEATHCOTE, J. G.; HIBBERT, J. R. Aflatoxins: Chemical and biological aspects. New York: Elsevier Science, 1978.

HELFERICH, W.G.; GARRETT, W.N.; HSIEH, D.P.H.; BALDWIN, R.L. Feedlot performance and tissue residues of cattle consuming diets containing aflatoxins. Journal of Animal Science, Albany, v.62, n.3, p.691-696, 1986a. 
HELFERICH, W. G.; BALDWIN, R. L.; HSIEH, D. P. H. $\left[{ }^{14} \mathrm{C}\right]$-aflatoxin $\mathrm{B}_{1}$ metabolism in lactating goats and rats. Journal of Animal Science, Albany, v.62, p.697-705, 1986b.

HERZBERG, P. A. How SAS works: a comprehensive introduction to the SAS system. Ottawa: Captus Press, 1990. 193p

HIESH, D.P.; WOGAN, J.J. Metabolismo and toxicity of aflatoxins. In:SNYDER, R.; PARK, D.V.; KOESIS, J.J.; JOLLOW, D.J.; GIBSON, G.G.; WITNER, C.M. Biological reactiver Intermediates. II Part B. New York, Plenum Publishers, 1982. p. 847 - 863.

HSIEH, D. P. H. Mode of action of mycotoxins. In: KROGH, P. (Ed.) Mycotoxins in food. London: Academic Press, 1987. 176p.

HUFF, W.E.; KUBENA, L.F.; HARVEY, R.B.; CORRIER, D.E; MOLLENHAUER, H.H. Progression of aflatoxicosis in broiler chickens. Poultry Science, Ithaca, v.65, n.10, p.1891-1899, 1986.

HUSSEIN, H. S.; BRASEL, J. M. Toxicity, metabolism, and impact of mycotoxins on humans and animals. Toxicology, Amsterdam, v.167, n.2, p.101-134, 2001.

JOENS, L. A.; PIER, A. C.; CUTLIP, R. C. Effects of aflatoxin consumption on the clinical course of swine dysentery. American Journal of Veterinary Research, Chicago, v.42, n.7, p.11701172, 1981.

JONES, F. T.; HAGLER, W. M.; HAMILTON, P. B. Association of low concentrations of aflatoxin in feed with productivity losses in commercial broiler operations. Poultry Science, Ithaca, v.61, n.5, p.861-868, 1982.

JONES, K. L.; JONES, S. E. Fermentation involved in the production of cocoa, coffee and tea. In: BUSHEL, M. E. (Ed.) Progress in industrial microbiology. Amsterdam: Elsevier Science Publisher, 1984. p.411-456.

KATO, I.; KOBAYASHI, S.; YOKOKURA, T.; MUTAI, M. Antitumor activity of Lactobacillus casei in mice. Gann, Tokyo, v.72, n.4, p.517-523, 1981. 
KRAUSE, O. G.; RICHARDSON, C. R.; CASTLEBERRY, R. E.; COBB, C. W. Biological response of chicks fed sorghum grain based diets with added grain specific enzymes mixture and yeast. Texas Technology of Agriculture Science, Texas, v.5, p.727-735, 1989.

KUBENA, L. E.; HARVEY, R. B.; PHILLIPS, T. D.; et al. Diminution of aflatoxicosis in growing chickens by the dietary addition of a hydrated sodium calcium aluminosilicate. Poultry Science, Ithaca, v.69, p.727-735, 1990.

KUMAGAI, S.; SUGITA-KONISHI, Y.; HARA-KUDO, Y.; ITO. Y.; NOGUCHI, Y.; YAMAMOTO, Y.; OGURA, $A$. The fate and acute toxicity of aflatoxin $B_{1}$ in the mastomys and rat. Toxicon, Oxford, v.36, n.1, p.179-188, 1998.

LANCASTER, M. C.; JENKINS, F. P.; PHILP, J. McL. Toxicity associated with certain samples of groundnuts. Nature, London, v.192, n.16, p.1095-6, 1961.

LILLEHOJ, E. D. The aflatoxin in maize problem: The historical perspective. In: WORKSHOP ON AFLATOXIN IN MAIZE, El Batan, 1986. Proceedings. El Batan: CIMMYT, 1986. p.13-32.

LUTHY, J.; ZWEIFEL, U.; SCHLATTER, C. Metabolism and tissue distribution of [C-14-labeled aflatoxin-B1 in pigs. Food and Cosmetics Toxicology, London, v.18, n.3, p.253-256, 1980.

MAHESH, B. K.; DEVEGOWDA, G. Ability of aflatoxin binders to bind aflatoxin contaminated poultry feeds and liquid media in vitro. In: SYMPOSIUM ON BIOTECHNOLOGY IN THE FEED INDUSTRY, 12., Lexington, 1996. Lexington: SBFI, 1996. p.1.1

MCLEAN, M.; DUTTON, M. Cellular interactions and metabolism of aflatoxin: An update. Pharmacology Therapeutic, London, v.65, p.163-192, 1995.

MGBODILE, M. U. K.; HOLSCHER, M.; NEAL., R. A. Possible protective role for reduced glutathione in Aflatoxin $B_{1}$ toxicity: effect of pretreatment of rats with phenobarbitol and 3 methylchoranthrene on aflatoxin toxicity. Toxicology and Applied Pharmacology, New York, v.34, n.1, p.128-142, 1975. 
MILLER, D. M.; STUART, B. P.; CROWELL, W. A.. Aflaroxicosis in swine: its effect on immunity and relationship to Salmonellosis. American Association Veterinary Laboratory Diagnostic, Hershey, v.21, p.135-146, 1978.

NABER, E. C.; WALLACE, H. D. Interactions of mycotoxins in animal production. Washinghton: National Academic Science, 979. p. 3-76.

NEWBERNE, P. M. Chronic aflatoxicosis. Journal American Veterinary Medical Association, Schaumburg, v.163, p.1262-1269, 1973.

NEWBERNE, P. M.; BUTLER, W. H. Acute and chronic effects of aflatoxin on liver of domestic and laboratory animals - a review. Cancer Research, Chicago, v.29, n.1, p.236-240, 1969.

NICHOLS, T. E. Economic effects of aflatoxin in corn. In: DIENER, R.; ASQUITH, R.; DICKENS, J. (Ed.) Aflatoxin and Aspergillus flavus in corn. Auburn: Auburn University, 1983. p.67-71

PACHECO, A. C. Compêndio básico de técnicas histológicas. Botucatu: UNESP, 1981.

PARKINSON, A. Biotransformation of xenobiotics. In: KLAASEN, C.D. (Ed.) Cassarett \& Doull's. toxicology. The basic Science of poisons. New York: Mc Graw-Hill, 1996. p.113186.

PARLAT, S. S.; OZCAN, M.; OGUZ, H. Biological suppression of aflatoxicosis in Japanese quail (Coturnix coturnix japonica) by dietary addition of yeast (Saccharomyces cerevisiae). Research in Veterinary Science, Oxford, v.71, n.3, p.207-211, 2001.

PATTERSON, D. S. Metabolism as a factor in determining toxic action of aflatoxins in different animal species. Food and Cosmetics Toxicology, London, v.11, n.2, p.287-294, 1973.

PERDIGON, G.; ALVAREZ, S. Probiotics and the immune state. In: FULLER, R. (Ed.) Probiotics - the scientific basis. London: Chapman and Hall, 1992. p.146-180. 
PHILLIPS, W. A.; VON TUNGELN, K. L. Effect of adding yeast culture to the receiving ration of stressed stocker calves. Stillwater: Oklahoma State University, Agricultural Experimental Station, 1984. p.117.

PÍER, A. C.; HEDDLESTON, K. L. The effect of aflatoxin on immunity in rurkeys. I. Impairment of actively acquired resistance to bacterial challenge. Avian Diseases, Ithaca, v.14, p.797-809, 1970.

PIERCE, J. S. Analysis committee measurement of yeast viability. Journal of the Institute of Brewing, London, v.76, n.5, p.442-443, 1970.

PIPER, P. W. Molecular events associated with acquisition of heat tolerance by the yeast Saccharomyces cerevisiae. Fems Microbiology Reviews, Amsterdam, v.11, n.4, p.339-356, 1993.

PIVA, G.; GALVANO, F. P. F.; PIETRI, A.; PIVA, A. Detoxification methods of aflatoxins - a review. Nutrition Research, New York, v.15, n.5, p.767-776, 1995.

POZZI, C. R. Efeitos da adminstração prolongada de Fumonisina B e Aflatoxina $B ı$ em ratos (Rattus norvegicus). 2000. 179 f. Tese (Doutorado) - Instituto de Ciências Biomédicas, Universidade de São Paulo, São Paulo, 2000.

RAJU, M. V. L. N.; DEVEGOWDA, G. Esterified-glucomannan in broiler chicken dietscontaminated with aflatoxin, ochratoxin and T-2 toxin: Evaluation of its binding ability (in vitro) and efficacy as immunomodulator. Asian-Australasian Journal of Animal Sciences, v.15, n.7, p.1051-1056, 2002.

REEVES, P. G.; NIELSEN, F. H.; FAHEY, G. C. Ain-93 purified diets for laboratory rodents - final report of the American Institute of Nutrition ad hoc writing committee on the reformulation of the ain-76a rodent diet. Journal of Nutrition, Bethesda, v.23, n.11, p.1939-1951, 1993. 
RICHARD, J. L.; THURSTON, J. R.; PIER, A. C. Micotoxin-induced alterations of immunity. In: SCHLESSINGER, P. (Ed.). Microbiology. Washington: American Society Microbiologists, 1975. cap.9, p.388-396.

ROBBINS, S. L.; ANGELL, M.; KUMAR, V. A doença em nível celular. In: ROBBINS, S. L.; ANGELL, M.; KUMAR, V (Ed.) Patologia básica. São Paulo: Ateneu, 1986. cap.1, p.3-31.

RODRICKS, J. V.; STOLOFF, L. Aflatoxins residues from contaminated Feed in edible tissues of food-producing animals. In: RODRICKS, J. V. C.; HESSELTINE, W.; MEHLMAN, M. A. (Ed.) Mycotoxins in human and animal health. Illinois: Park Forest South, 1977. p.67-69.

ROEBUCH, B. D.; MAXUILENKO, Y. Y. Biochemical mechanism and biological implications of the toxicity of Aflatoxins as related to Aflatoxin carcinogenesis. In: EATON, D.L.; GROOPMAN, J.D. (Ed). The toxicology of aflatoxins. London: Academic Press, 1994. p. $27-43$.

ROEBUCK, B. D.; WOGAN, G. N. Species comparison of in vitro metabolism of aflatoxin-B1. Cancer Research, Chicago, v.37, n6, p.1649-1656, 1977.

ROSE, A. H.; HARRISON, J. N. The yeasts. London: Academic Press, 1970. v3, 590p.

ROSINI, G.; FEDERICI, F.; MARTINI, A. Yeast flora of grape berries during ripening. Microbial Ecology, New York, v.8, p.83-89, 1982.

RUSSELL, L.; COX, D. F.; LARSEN, G.; BODWELL, K.; NELSON, C. E. Incidence of molds and mycotoxins in commercial animal feed mills in 7 midwestern states, 1988-1989. Journal of Animal Science, Albany, v.69, n.1, p.5-12, 1991.

SAAVEDRA, J. M.; BAUMAN, N. A.; OUNG, I.; et al. Feeding of Bifidobacterium bifidum and Streptococcus thermophilus to infants in hospital to prevention of diarrhoea and shedding of rotavirus. Lancet, Barcelona, v.344, p.1046-1049, 1994. 
SALAY, E.; MERCADANTE, A. Z. Mycotoxins in Brazilian corn for animal feed: occurrence and incentives for the private sector to control the level of contamination. Food Control, Guildford, v.13, n.2, p.87-92, 2002.

SAWADA, H.; FURUSHIRO, M.; HIRAI, K.. Purification and characterization of an antihypertensive compound from Lactobacillus casei. Agricultural and Biological Chemistry Journal, Tokyo, v.54, p.3211-3219, 1990.

SHI, C. Y.; HEW, Y. C.; ONG, C N. Inhibition of aflatoxin b1-induced cell injury by selenium - an in-vitro study. Human \& Experimental Toxicology, Basingstoke, v.14, n.1, p.55-60, 1995.

SILLJE, H. H. W.; PAALMAN, J. W. G.; TER-SCHURE, E. G.; et al. Function of trehalose and glycogen in cell cycle progression and cell viability in Saccharomyces cerevisiae. Journal of Bacteriology, Baltimore, v.181, n.2, p.396-400, 1999.

SILVA, N.; JUNQUEIRA, V. C. A.; SILVEIRA, N. F. A. Manual de métodos de análise microbiológica de alimentos. São Paulo: Varela, 1997. 295p.

SKRINJAR, M.; DANEV, M.; DIMIC, G. Investigation on the presence of toxigenic fungi and aflatoxins in raw milk. Acta Alimentaria, Budapest, v.24, n.4, p.395-402, 1995.

SMITH, E. E.; KUBENA, L. F.; BRAITHWAITE, C. E.; HARVEY. R. B.; PHILLIPS, T. D.; REINE, A. H. Toxicological evaluation of aflatoxin and cyclopiazonic acid in broiler-chickens. Poultry Science, thaca, v.71, n.7, p.1136-1144, 1992.

SMITH, J.E.; MOSS, M.O. Mycotoxins: formation, analysis, and significance. Chichester: Wiley, 1985. 148p.

SOARES, L. M. V.; RODRIGUES-AMAYA, D.B. Survey of aflatoxins, ochratoxin A, zearalenone and sterigmatocystin in some Brazilian food by using multi-toxin thin-layer chromatografic method. Journal of the AOAC, Washington, v.72, p.22-26, 1989.

SOUTHERN, L. L.; CLAWSON, A. J. Effects of aflatoxins on finishing swine. Journal of Animal Science, Albany, v.49, n.4, p.1006-1011, 1979. 
STANLEY, V. G.; OJO, R.; WOLDESENBET, S.; HUTCHINSON, D. H.; KUBENA, L. F. The use of Saccharomyces cerevisiae to suppress the effects of aflatoxicosis in broiler chicks. Poultry Science, thaca, v.72, p.1867-1872, 1993.

STARK, A. Molecular aspects of aflatoxin BI mutagenesis and carcinogenesis. In: STEYN, P.S.; VLEGGAAR, R. (Ed.) Micotoxins and phycotoxins. Amsterdam: Elsevier Science, 1986. v.1, p435-445.

STOLOFF, L. Aflatoxin: a overview. In: RODRICKS, J.V C.; HESSELTINE, W.; MEHLMAN, M.A. (Ed.) Mycotoxins in human and animal health. Park Forest South: Patholox Publishers, 1977. cap.1, p.7 - 28.

SUSSMAN, A. S.; LINGAPPA, B. T. Role of trehalose in ascopores of Neurospora tetrasperma Nature, London, v.130, p.1343, 1959.

SWENSON, D. H.; MILLER, E. C.; MILLER. J. A. Aflatoxin b1-2,3-oxide - evidence for its formation in rat-liver in vivo and by human liver-microsomes in vitro. Biochemical and Biophysical Research Communications, New York, v.60, n.3, p.1036-1043, 1974.

THERON, J. J. Acute liver injury in ducklings as a result of aflatoxin poisoning. Laboratory Investigation, New York, v.14, n.9, p.1586-1603, 1965.

THURSTON, J.R.; BAETZ. A;L.; CHEVILLE. N.F.; RICHARD. J.L. Acute aflatoxicosis in guinea pigs - sequential-changes in serum-proteins, complement, C-4, and liver-enzymes and histopathologic changes. American Journal of Veterinary Research, Chicago, v.41, n.8, p.1272-1276, 1980.

TREVELYAN, W. E.; HARRISON, J. S. Studies on yeast metabolism. V. The trehalose content of baker's yeast during a anaerobic fermentation. Biochemical Journal, London, v.62, n.2, p.177-183, 1956. 
VASANTHI. S.; BHAT, R. V. Mycotoxins in foods - Occurrence, health \& economic significance \& food control measures. Indian Journal of Medical Research, Calcutta, v.108, p.212-224, 1998.

WOGAN, G. N. Aflatoxin carcinogenesis. Methods Cancer Research, v.7, p.303-344, 1973.

WOGAN, G. N.; EDWARDS, G. S.; SHANK, R. C. Excretion and tissue distribution of radioactivity from aflatoxin $B_{1}-\left[{ }^{14} C\right]$ in rats. Cancer Research, Chicago, v.27, p.1729 1936, 1967.

WONG, Z. A.; HSIEH, D. P. H. The comparative metabolism and toxicokinetics of aflatoxin-b1 in the monkey, rat, and mouse. Toxicology and Applied Pharmacology, New York, v.55, n.1, p.115-125, 1980.

YIANNIKOURIS, A.; POUGHON, L.; CAMELEYRE, X.; DUSSAP, C. G.; FRANCOIS, J.; BERTIN, G.; JOUANY, J. P. A novel technique to evaluate interactions between Saccharomyces cerevisiae cell wall and mycotoxins: application to zearalenone. Biotechnology Letters, Kew, v.25, n.10, p.783-789, 2003. 